


\section{Tussenevaluatie POP3-maatregelen cluster Concurrentiekracht}

Gabe Venema, Harold van der Meulen, Ruud van der Meer, Petra Berkhout, Rob Stokkers, Nico Bondt, Piet Rijk

Dit onderzoek is uitgevoerd door Wageningen Economic Research in opdracht van en gefinancierd door het ministerie van Landbouw, Natuur en Voedselkwaliteit.

Wageningen Economic Research

Wageningen, juni 2019

RAPPORT

2019-065

ISBN 978-94-6395-010-7 
Gabe Venema, Harold van der Meulen, Ruud van der Meer, Petra Berkhout, Rob Stokkers, Nico Bondt, Piet Rijk, 2019. Tussenevaluatie POP3-maatregelen cluster Concurrentiekracht. Wageningen, Wageningen Economic Research, Rapport 2019-065. 78 blz.; 20 fig.; 9 tab.; 4 ref.

Het Plattelandsontwikkelingsprogramma Nederland 2014-2020 (POP3) beoogt de innovatie en een duurzame modernisering van de agrarische sector te bevorderen. Versterking van biodiversiteit en vitaal platteland zijn andere belangrijke doelen. Het programma wordt zowel tijdens de looptijd als na afloop geëvalueerd. In 2019 dient Nederland aan de Europese Commissie te rapporteren over de voortgang van het POP3 over de periode 2014-2018. In dit rapport wordt inzicht gegeven in de voortgang in deze periode van vier maatregelen uit het cluster Concurrentiekracht: Kwaliteitsregeling Kalveren, Productieve fysieke investeringen, Jonge Landbouwersregeling en Verbetering verkaveling. Deze maatregelen beogen het POP3-doel versterken van de agrarische bedrijfsstructuur.

In deze tussenevaluatie wordt inzicht gegeven in het bereik (in welke mate worden begrote budgetten en streefwaarden bereikt) en de mate van doeltreffendheid, waarin zowel ingegaan wordt op gerealiseerde als nog te verwachten effecten in komende jaren van de ingezette middelen. Ook wordt inzicht gegeven in de uitvoering en organisatie van de vier maatregelen, waarbij ook aanbevelingen worden gedaan voor aanpassing van de uitvoering.

Trefwoorden: POP3, tussenevaluatie, cluster concurrentiekracht, jonge landbouwers, duurzame investeringen, verkavelingsstructuur, kwaliteitsregeling kalveren

Dit rapport is gratis te downloaden op https://doi.org/10.18174/494426 of op www. wur. nl/economicresearch (onder Wageningen Economic Research publicaties).

(C) 2019 Wageningen Economic Research

Postbus 29703, 2502 LS Den Haag, T 07033583 30, E communications.ssg@wur.nl, www.wur.nl/economic-research. Wageningen Economic Research is onderdeel van Wageningen University \& Research.

\section{(cc) BY-NC}

Dit werk valt onder een Creative Commons Naamsvermelding-Niet Commercieel 4.0 Internationaallicentie.

(C) Wageningen Economic Research, onderdeel van Stichting Wageningen Research, 2019 De gebruiker mag het werk kopiëren, verspreiden en doorgeven en afgeleide werken maken. Materiaal van derden waarvan in het werk gebruik is gemaakt en waarop intellectuele eigendomsrechten berusten, mogen niet zonder voorafgaande toestemming van derden gebruikt worden. De gebruiker dient bij het werk de door de maker of de licentiegever aangegeven naam te vermelden, maar niet zodanig dat de indruk gewekt wordt dat zij daarmee instemmen met het werk van de gebruiker of het gebruik van het werk. De gebruiker mag het werk niet voor commerciële doeleinden gebruiken.

Wageningen Economic Research aanvaardt geen aansprakelijkheid voor eventuele schade voortvloeiend uit het gebruik van de resultaten van dit onderzoek of de toepassing van de adviezen.

Wageningen Economic Research is ISO 9001:2008 gecertificeerd.

Wageningen Economic Research Rapport 2019-065 | Projectcode 2282500300

Foto omslag: Shutterstock 


\section{Inhoud}

$\begin{array}{ll}\text { Woord vooraf } & 5\end{array}$

$\begin{array}{ll}\text { Samenvatting } & 6\end{array}$

S.1 Belangrijkste resultaten $\quad 6$

S.2 Bereik maatregelen binnen cluster Concurrentiekracht $\quad 6$

$\begin{array}{lll}\text { S.3 Doeltreffendheid } & 8\end{array}$

S.4 Aanbevelingen 9

S.5 Aanleiding en doel onderzoek 10

1

\section{Inleiding}

$1.1 \quad$ Aanleiding $\quad 11$

1.2 Doelstelling $\quad 11$

1.3 Onderzoeksvragen en aanpak 12

$\begin{array}{lll}1.4 & \text { Opbouw van het rapport } & 13\end{array}$

2

Kwaliteitsregeling Kalveren (maatregel 3) 14

$\begin{array}{lll}2.1 & \text { Beleidstheorie } & 14\end{array}$

$\begin{array}{lll}2.2 & \text { Bereik } & 15\end{array}$

$\begin{array}{lll}2.3 & \text { Doeltreffendheid } & 16\end{array}$

$\begin{array}{lll}2.4 & \text { Doelmatigheid } & 17\end{array}$

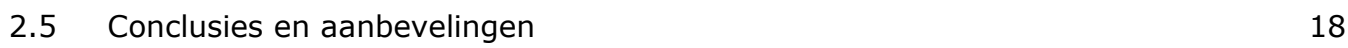

$3 \quad$ Productieve fysieke investeringen (maatregel 4.1.1) 19

$\begin{array}{lll}3.1 & \text { Beleidstheorie } & 19\end{array}$

$\begin{array}{lll}3.2 & \text { Bereik } & 21\end{array}$

$\begin{array}{lll}3.3 & \text { Doeltreffendheid } & 23\end{array}$

$\begin{array}{ll}3.4 & \text { Doelmatigheid }\end{array}$

3.5 Conclusies en aanbevelingen $\quad 31$

$4 \quad$ Jonge landbouwers-regeling (maatregel 4.1.2) 33

4.1 Beleidstheorie $\quad 33$

$\begin{array}{lll}4.2 & \text { Bereik } & 35\end{array}$

$\begin{array}{lll}4.3 & \text { Doeltreffendheid } & 37\end{array}$

4.3.1 Resultaten enquête en bevindingen interviews 37

$\begin{array}{lll}4.4 & \text { Doelmatigheid } & 42\end{array}$

$\begin{array}{lll}4.5 & \text { Conclusies en aanbevelingen } & 43\end{array}$

$5 \quad$ Verbetering verkaveling (maatregel 4.3) 44

$\begin{array}{lll}5.1 & \text { Beleidstheorie } & 45\end{array}$

$\begin{array}{lll}5.2 & \text { Bereik } & 46\end{array}$

$\begin{array}{lll}5.3 & \text { Doeltreffendheid } & 47\end{array}$

$\begin{array}{lll}5.4 & \text { Doelmatigheid } & 48\end{array}$

5.5 Verplaatsing glastuinbouwbedrijven $\quad 50$

5.5.1 Beleidstheorie $\quad 50$

$\begin{array}{ll}5.5 .2 \text { Bereik } & 50\end{array}$

5.5.3 Doeltreffendheid 51

5.5.4 Doelmatigheid 52

5.6 Conclusies en aanbevelingen $\quad 52$ 
Bijlage 1 Maatregel Kwaliteitsregeling Kalveren 55

Bijlage 2 Maatregel Productieve fysieke investeringen 56

Bijlage 3 Maatregel Jonge landbouwers 63

Bijlage 4 Maatregel Verbetering verkaveling 70

Bijlage 5 Budgetten cluster Concurrentiekracht 73

Bijlage 6 Tussenevaluatie Brede weersverzekering 74

Bijlage 7 Tussentijdse beantwoording algemene vragen EU (bijvangst) 76 


\section{Woord vooraf}

Het Nederlandse Plattelandsprogramma 2014-2020 (POP3) is een Europees subsidieprogramma voor de ontwikkeling van een concurrerende duurzame en innovatie landbouw, het versterken van de biodiversiteit en een vitaal platteland. Het POP valt onder de tweede Pijler van het Gemeenschappelijk Landbouwbeleid van de EU. In 2019 dient Nederland aan de Europese Commissie te rapporteren over de voortgang van het POP3 over de periode 2014-2018. In opdracht van het Regiebureau POP (onderdeel van het ministerie van Landbouw, Natuur en Voedselkwaliteit) heeft Wageningen Economic Research opdracht gekregen de tussenevaluatie van vier maatregelen uit POP3, alle behorend tot het cluster Concurrentiekracht, uit te voeren. Deze maatregelen beogen een bijdrage te leveren aan het volgende doel (dit is 1 van de 6 hoofddoelen van POP3): het versterken van het concurrentievermogen in de landbouw en het verbeteren van de rentabiliteit. In deze tussenevaluatie wordt inzicht gegeven in het bereik, de mate van doeltreffendheid en de aspecten uitvoering en organisatie. Ook worden aanbevelingen gedaan voor mogelijke aanpassingen.

Voor de realisatie van dit onderzoek willen we de volgende instanties hartelijk danken voor hun tijd en inzet: de provincies (met name meerdere POP-coördinatoren), het agrarische bedrijfsleven (accountants- en adviesbureaus, banken), de agrarische belangenbehartiging (LTO en NAJK) en LNV De Rijksdienst voor Ondernemend Nederland wordt bedankt voor hun grote inzet voor de aanlevering van de relevante gegevens om deze tussenvaluatie mogelijk te maken. Maar bovenal een woord van dank voor de agrarische ondernemers die meegedaan hebben aan de twee enquêtes, die veel waardevolle aanvullende informatie hebben opgeleverd.

Het onderzoek is begeleid door een brede commissie bestaande uit het Regiebureau POP, LNV, provincies, RVO en BIJ12 onder voorzitterschap van René Strijder. Een speciaal woord van dank gaat uit naar Fer Schenk, ons eerste aanspreekpunt vanuit het Regiebureau POP, voor zijn constructieve bijdragen aan het onderzoeksresultaat.

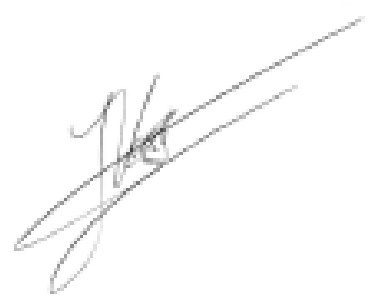

Prof.dr.ir. J.G.A.J. (Jack) van der Vorst Algemeen Directeur Social Sciences Group (SSG) Wageningen University \& Research 


\section{Samenvatting}

\section{S.1 Belangrijkste resultaten}

- Na een moeizame opstart van POP3 ligt de budgetbesteding in toenemende mate op koers. Vooral in 2018 is een flinke inhaalslag gemaakt.

- Provincies investeren nogal uiteenlopend in de maatregelen die vallen onder het cluster Concurrentiekracht. Met name bij de maatregel Verbetering verkaveling (inclusief bedrijfsverplaatsing) zijn de verschillen tussen provincies groot. Het realiseren van eigen beleidsprioriteiten speelt een belangrijke rol. Dit zien we vooral bij de maatregel Productieve fysieke investeringen en in mindere mate bij de maatregel Jonge landbouwers (JoLa). Sommige provincies stimuleren nauwelijks de intensieve veehouderij, anderen stimuleren sterk de biologische landbouw.

- De streefwaarde voor de maatregel Kwaliteitsregeling vleeskalveren is al bereikt. Ook de JoLa ligt op koers, Het toegekende budget productieve fysieke investeringen blijft eind 2018 achter, mede door een late opstart van de openstellingen en door het wennen aan procedures. Veel provincies hebben een duidelijke inhaalslag gemaakt, met relatief veel aanvragen eind 2018 die nog moeten worden beschikt. Opvallend is het grote aantal niet goedgekeurde aanvragen onder de regeling productieve fysieke investeringen. Dit overstijgt het aantal goedkeuringen en het goedgekeurde budget. Gezien de bijkomende indieningskosten werkt dit niet stimulerend voor ondernemers.

- De ondersteuning via de maatregelen JoLa en Productieve fysieke investeringen heeft vooral geleid tot een verdere verduurzaming van bedrijfsprocessen, veelal via modernisering en innovatieve investeringen. Veel van deze investeringen zijn naar voren gehaald.

- De inkomenseffecten van de inzet van maatregelen binnen het cluster Concurrentiekracht zullen naar verwachting relatief beperkt zijn. Dit komt mede doordat Nederland de beleidskeuze heeft gemaakt binnen dit cluster zich te richten op het stimuleren van bovenwettelijke investeringen gericht op verduurzaming, klimaat en dierenwelzijn. Ook betreft het voor een aanzienlijk deel van de bedrijven een relatief beperkte investering, zoals bij de JoLa. De verwachting is dat door meerdere van de ingezette maatregelen vooral de bedrijfskosten (in beperkte mate) zullen dalen, Er zullen nauwelijks inkomenseffecten zijn door middel van opbrengstverhogingen.

- Verkaveling van grond heeft een gunstig effect op de structuur van bedrijven . Bij projecten met meervoudige doelen worden in sterke mate positieve effecten bereikt. Vooral natuur- en waterdoelen krijgen lokaal belangrijke impulsen mee, evenals verkeersveiligheid. Vanwege relatief geringe belangstelling hebben veel provincies voorgesteld tot een sterke overheveling van budget van de maatregel Verbetering verkaveling gedurende POP3 naar andere clusters. Naast beleidsprioritering spelen de procedures rond het indienen van verkavelingsprojecten hierbij een rol.

- De specifieke regeling Fysieke investeringen voor innovatie en modernisering van agrarische ondernemingen in de Veenkoloniën is in goed overleg en naar tevredenheid ingevuld en uitgezet.

\section{S.2 Bereik maatregelen binnen cluster Concurrentiekracht}

\section{Budget}

Bij de start van het programma is $€ 332,78 \mathrm{mln}$. begroot voor het cluster Concurrentiekracht. Dit budget betreft zowel EU-budget als co-financieringsbudget van provincies of Rijk. De start van het programma is moeizaam verlopen vanwege aangescherpte regels van de EU, met name tot uiting komend bij de verkavelingsopgaven. De provincies hebben gedurende het programma voorstellen voorbereid om budget te verschuiven, zowel tussen clusters als tussen maatregelingen. Dit is mede op basis van opgedane ervaringen rond inschrijvingsprocedures en soms door beleidsprioritering. In deze evaluatie is alvast rekening gehouden met de budgetverschuivingen, die leiden tot een lager totaalbudget voor het cluster Concurrentiekracht gedurende POP3. De voorgestelde verschuivingen zijn echter nog niet geëffectueerd door het Comité van Toezicht. 
Eind 2018 is het voorstel $€ 261,07 \mathrm{mln}$. voor het cluster Concurrentiekracht te reserveren. De budgetdaling binnen dit cluster vindt plaats bij maatregel Verbetering Verkaveling ( $€-58,3 \mathrm{mln}$.) en maatregel Productieve fysieke investeringen $(€-13,4 \mathrm{mln}$.). De beschikbare budgetten voor de overige maatregelen onder cluster Concurrentiekracht blijven op hetzelfde niveau.

Het Rijk is verantwoordelijk voor de uitvoering van maatregel Kwaliteitsverbetering kalveren, de regeling Productieve fysieke investeringen kalverhouderij en de maatregel Brede weersverzekering (totaalbudget $€ 91,69 \mathrm{mln}$.). De provincies voeren de maatregelen Productieve fysieke Investeringen, de JoLa en Verbetering Verkaveling uit (totaalbudget $€ 169,38 \mathrm{mln}$.).

Het budget van provincies loopt sterk uiteen: van $€ 4,24 \mathrm{mln}$. (Zuid-Holland) tot $€ 22,25 \mathrm{mln}$. (Limburg). Door de moeizame start zijn de regelingen binnen het cluster Concurrentiekracht pas opengesteld vanaf 2016, met uitzondering van de brede weersverzekering die vanaf 2015 loopt. De maatregel Productieve fysieke investeringen blijft qua budgetuitputting achter. Dit heeft vooral te maken met het ervaring opdoen met openstellingsprocedures.

Vanaf 2018 lopen de maatregelen binnen het cluster Concurrentiekracht veel beter en is er een aanzienlijke inhaalslag gemaakt. Meerdere lopende of in 2018 afgesloten openstellingen worden in 2019 beoordeeld en toegewezen.

\section{Streefwaarden}

De maatregel Kwaliteitsverbetering kalveren heeft het beoogde aantal bedrijven (1.700) dat meedoet aan Vitaal Kalf eind 2018 met 1.729 goedgekeurde aanvragen behaald (tabel S.1). Voor de maatregelen die ingezet worden onder maatregel 4 (Investeringen) wordt een totale streefwaarde beoogd van 3.500 ondersteunende bedrijven.

De goedkeuringen in de maatregel JoLa liggen met 1.248 goed op koers, met bijna driekwart van de streefwaarde. Samen met de maatregel Productieve fysieke investeringen (370, een kwart van de streefwaarde) en de maatregel Verbetering verkaveling (46) zijn eind 20181.664 aanvragen goedgekeurd (48\% van de streefwaarde 3.500). Daarbij vermeldend dat een aantal goedgekeurde aanvragen binnen de maatregel Productieve fysieke investeringen, maar bovenal binnen de maatregel Verbetering verkaveling, zich uitspreiden naar meerdere bedrijven die ermee worden ondersteund. Mede gezien het grote aantal nog te beoordelen dossiers begin 2019, met name onder de maatregel Productieve fysieke investeringen, en vanaf eind 2018 nog lopende openstellingen, mag worden geconstateerd dat na een late opstart het aantal begunstigde bedrijven op koers ligt.

Tabel S.1 Bereik budget en streefwaarden per maatregel

\begin{tabular}{lrr} 
Maatregel & $\begin{array}{r}\text { Budget (\% besteed) } \\
\text { in } \mathrm{C} \mathrm{mln.}\end{array}$ & $\begin{array}{c}\text { Aantal (\% streefwaarde) } \\
\text { Kwaliteitsregeling Kalveren }\end{array}$ \\
\hline Productieve Fysieke Inv. & $38(37)$ & $1.729(102)$ Uitstekend \\
\hline Jonge landbouwers (JoLa) & $21(59)$ & $397(25)$ Redelijk \\
Verbetering verkaveling & $28(55)$ & $1.248(73)$ Goed \\
Brede weersverzekering & $38,0(91)$ & 46 Redelijk \\
\hline Totaal & $151,2(58)$ & 2.012 Goed \\
\hline
\end{tabular}

Bron: RVO

Het goedgekeurde budget (ofwel de toegekende subsidies) over de periode 2014-2018 bedroeg $€ 151 \mathrm{mln}$., ofwel $58 \%$ van het totaal beschikbare budget. De provincie Gelderland is koploper met ruim $€ 20$ mln., gevolgd door Noord-Brabant (figuur 1). In deze twee provincies bevinden zich veel van de Nederlandse kalverhouders. Daarna volgt Noord-Holland, een provincie die relatief sterk heeft ingezet op verkaveling (inclusief verplaatsing). Het goedgekeurde budget tot en met 2018 onder het cluster Concurrentiekracht bleef met name in de provincies Utrecht, Zuid-Holland en Drenthe onder de $€ 5 \mathrm{mln}$. Dit komt mede door geen of nauwelijks openstellingen binnen de maatregel Verbetering verkaveling. 


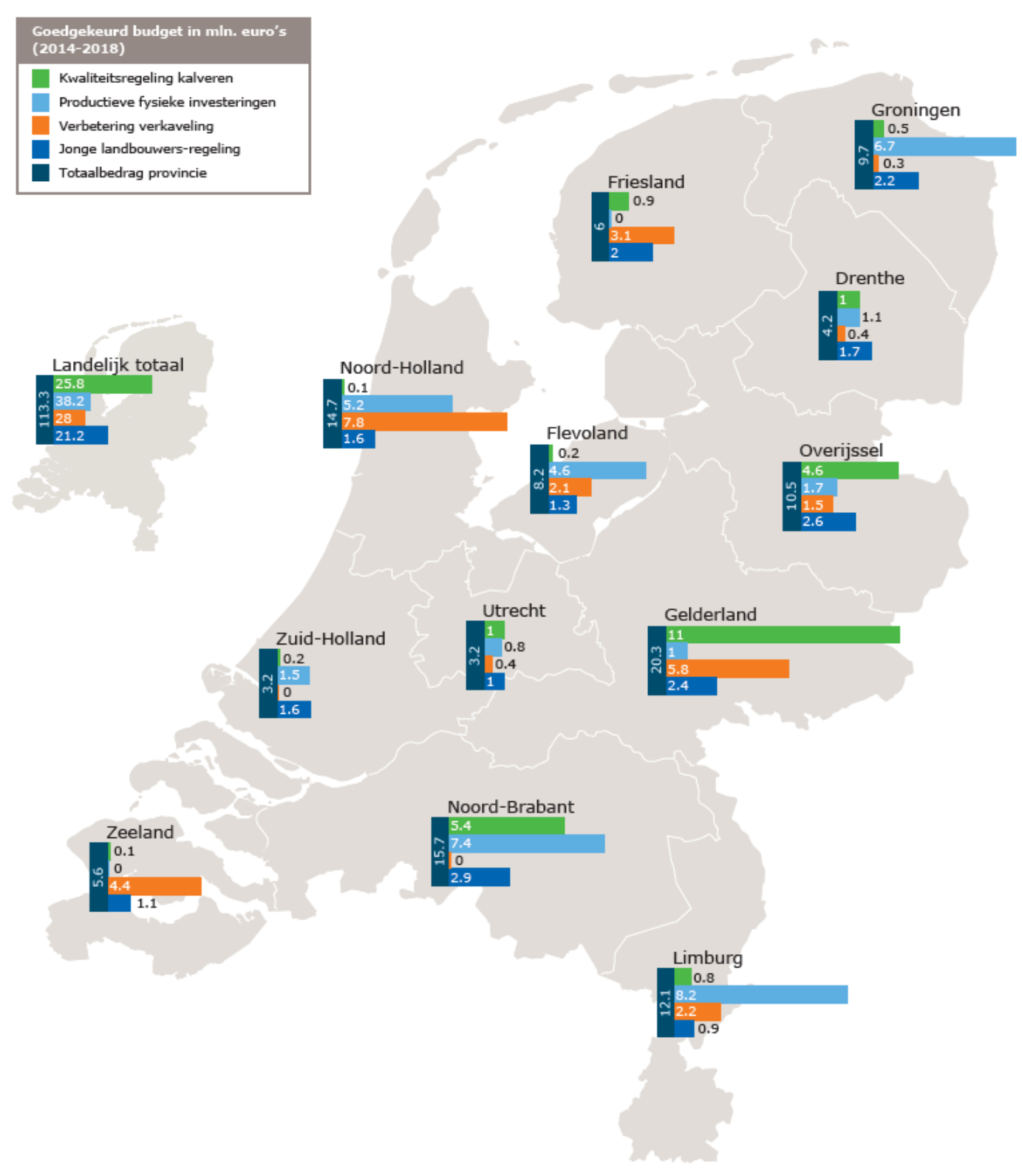

Figuur S.1 Goedgekeurde budgetten 4 geëvalueerde maatregelen binnen cluster Concurrentiekracht, verdeeld naar provincies, 2014-2018

Opmerking: Kwaliteitsregeling Kalveren wordt door het ministerie van LNV uitgevoerd.

Door de late start van POP3 met openstellingen in vooral in de periode 2016-2018 zijn er nog geen beschikbare meetbare effecten op meerdere thema's als gevolg van de ingezette middelen. Dit geldt met name voor de inkomenseffecten. De beantwoording van de evaluatievragen is dan ook vooral gericht op de te verwachten effecten in de komende jaren, zoals ook aangegeven door de verschillende informatieverstrekkers in deze evaluatie.

\section{S.3 Doeltreffendheid}

- De verwachting is dat in de komende jaren met name (specifieke categorieën) bedrijfskosten zullen dalen door modernisering en innovatie via de maatregel Productieve fysieke investeringen, door bedrijfsverplaatsingen en door effecten op de bedrijfsvoering door verbeterde verkaveling. Ook de Kwaliteitsregeling kalveren zal leiden tot een verlaging van de bedrijfskosten op het terrein van diergezondheid en gebruik van middelen, zoals antibiotica. Binnen de maatregel JoLa zullen bepaalde typen investeringen verricht door jonge agrariërs, met name in zonnepanelen, zich na een iets langere periode terugverdienen. 
- De verwachting is dat de bedrijfsopbrengsten niet zozeer worden beïnvloed door de inzet van de POP3-subsidies onder dit cluster. Er is ingezet op bovenwettelijke investeringen die niet de komende jaren direct tot meer opbrengsten zullen leiden. Wel kan de certificering Vitaal Kalf ervoor zorgen dat de verkoop van kalfsvlees met een beter imago en kwaliteit tot hogere productprijzen leidt.

- De maatregelen JoLa en Productieve fysieke investeringen zetten in op het ondersteunen van bovenwettelijke investeringen. Deze investeringen worden hiermee naar voren gehaald. Er wordt een sterke impuls gegeven aan verduurzaming op verschillende thema's zoals dierenwelzijn, energie (zonnepanelen), gesloten kringlopen, precisielandbouw, biologische landbouw, bodembeheer en waterbeheer. Specifiek op milieu gericht zijn bijvoorbeeld investeringen in emissiebeperkende apparatuur. Hiermee zijn de ondersteunde bedrijven beter in staat in te spelen op mogelijke toekomstige regelgeving en invloeden vanuit de markt (consumentenwensen). Dit laatste is ook van toepassing door ondersteuning van keurmerk Vitaal Kalf. De ondersteuning van bedrijfsverplaatsing leidt tot moderne en innovatieve glastuinbouwbedrijven.

- Het effect via marktdeelname en landbouwdiversifiëring onder het cluster Concurrentiekracht is over het algemeen beperkt. De bedrijfsverplaatsingen in de glastuinbouw naar concentratiegebieden dicht bij de ketenpartijen kan een economisch voordeel bieden door versterking van de keten.

- Een relatief klein verbeterd inkomensperspectief kan een beperkt positief effect op de concurrentiekracht van sectoren hebben. Er wordt binnen het cluster sterk ingestoken op verduurzaming en modernisering van bedrijven. Naast beperkte inkomenseffecten, zal het via de nu nog bovenwettelijke investeringen of kwaliteitssystemen beter in kunnen spelen op markt- en beleidsontwikkelingen in komende jaren. Zo kan het keurmerk Vitaal Kalf een bijdrage leveren aan een soort 'licence to produce' voor de sector.

- Onder het cluster Concurrentiekracht wordt de overname van landbouwbedrijven niet op directe wijze ondersteund. Ook het meer indirecte effect van de JoLa-regeling op het besluit tot bedrijfsovername is beperkt. De subsidie is immers gering in vergelijking tot de financiering van de bedrijfsovername, en wordt daarnaast vooral ingezet op bovenwettelijke investeringen, gericht op duurzaamheid, klimaatbestendigheid en dierenwelzijn. Dit laatste leidt ook tot extra benodigde financiering voor jonge agrariërs in een periode waarin de financieringslasten (met name direct na de overname) hoog zijn.

- De bedrijfsverplaatsing glastuinbouw in Gelderland vindt vooral plaats door bedrijven met een relatief jonge ondernemer, of bedrijven die nog in overnameproces zitten. Deze nieuwe moderne bedrijven hebben naar verwachting een (klein) positief effect op een goede generatiewisseling en bieden meer toekomstperspectief. Het betreft echter maar een beperkt aantal bedrijven. Ook een goede verkaveling levert een bijdrage tot meer bedrijfsperspectief.

\section{S.4 Aanbevelingen}

De aanbevelingen zijn per maatregel beschreven en richten zich in grote mate op de doelmatigheid.

Kwaliteitsregeling kalveren

- Analyseer over 2 jaar een aantal indicatoren voor de vitaliteit van kalveren, zoals uitval en antibioticagebruik, om de verwachte positieve effecten met harde(re) cijfers te onderbouwen.

- In de sector wordt verder gewerkt aan terugkoppeling van gezondheidsinformatie in de keten. Onderzoek over 2 jaar hoe de informatieverstrekking functioneert, welke ervaringen veehouders hebben, en welke effecten er zijn op kalvergezondheid, op melkvee- als kalverbedrijven.

Productieve fysieke investeringen

- Continueer de huidige regeling Fysieke investeringen, maar streef tussen provincies naar meer harmonisatie en samenwerking, in uitvoering (openstellingen, procedures) en inhoud (meer gelijktrekken van investeringsmogelijkheden).

- Probeer een systematiek aan te houden waarbij het percentage afwijzingen wordt beperkt. Dit lag in de periode 2016-2018 bij de maatregel Productieve fysieke investeringen erg hoog. Dit kan ook door verschuiving van beschikbaar budget in de laatste jaren POP3.

- Probeer in de opeenvolgende openstellingen te variëren in investeringen, zodat meerdere landbouwsectoren gedurende de POP3-periode aan bod komen. In sommige provincies gebeurt dit al. 
Jonge landbouwers (JoLa)

- Houd de 'basis' investeringslijst constant en voeg investeringscategorieën toe met meer oog voor kleine of specifieke deelsectoren

- Onderzoek de mogelijkheden en wenselijkheid om via verschuivingen van middelen extra budget toe te delen aan deze regeling, gezien de grote interesse onder jonge agrariërs, en daarmee verdere vergroting van het bereik onder de hele groep jonge agrariërs.

Verbetering verkaveling

- De provincies kunnen in grotere mate hun leerervaringen rond open inschrijvingsprocedures met elkaar delen;

- De praktijk heeft een sterke behoefte aan meer uniformiteit in procedures en openstellingen.

\section{S.5 Aanleiding en doel onderzoek}

Het Plattelandsontwikkelingsprogramma 2014-2020 (POP3) beoogt de innovatie en duurzame modernisering van de agrarische sector te bevorderen. Het programma wordt zowel tijdens de looptijd als na afloop geëvalueerd. In 2019 dient Nederland aan de Europese Commissie te rapporteren over de voortgang van POP3 over de periode 2014-2018. Ten behoeve van deze voortgang geeft deze publicatie inzicht in de voortgang van de volgende vier maatregelen uit het cluster Concurrentiekracht:

- Maatregel 3 Kwaliteitsregeling Kalveren

- Maatregel 4.1.1. Productieve fysieke investeringen

- Maatregel 4.1.2. Jonge landbouwers-regeling (JoLa)

- Maatregel 4.3 Verbetering verkaveling

Maatregel 17.1.0 Brede weersverzekering is ook onderdeel van het cluster Concurrentiekracht, en is al in 2016 geëvalueerd.

De maatregelen binnen het cluster Concurrentiekracht vallen binnen POP3 onder het doel 'het versterken van de agrarische bedrijfsstructuur'. Deze versterking kan een belangrijke bijdrage leveren aan een verbetering van de inkomenspositie van agrarische ondernemers, aan de verduurzaming van het bedrijfsproces en daarmee aan de concurrentiepositie van agrarische sectoren in Nederland. Daarnaast wordt getracht een bijdrage te leveren aan natuur- en milieudoelstellingen van overheden. POP3 had in Nederland een moeilijke start. Het programma is pas in de loop van 2015 goedgekeurd door de Europese Commissie. Eind 2015 zijn de eerste openstellingen binnen het cluster Concurrentiekracht opengezet. De openstellingen vonden vooral in de jaren 2016 tot en met 2018 plaats. Het is daarom niet mogelijk al meetbare resultaten (effecten) te verkrijgen voor deze tussenevaluatie en een goed onderbouwde beoordeling te geven over de doeltreffendheid van de maatregelen. Dit onderzoek geeft vooral aan wat op basis van de verworven informatie voor de komende jaren (ook na 2020) aan effecten mag worden verwacht.

Met behulp van de beschikbare kwantitatieve informatie van de uitvoeringsorganen provincies en RVO (de laatste is ook betaalorgaan) en het Regiebureau POP is het bereik van de maatregelen binnen dit cluster in kaart gebracht. In combinatie met (diepte-)interviews met deskundigen, twee representatieve enquêtes onder ondernemers die subsidie hebben ontvangen, deskstudie en expertise van het onderzoeksteam is een beoordeling gegeven van de te verwachten doeltreffendheid van de ingezette maatregelen. Als bijvangst van deze evaluatie worden ook de belangrijkste bevindingen rond het proces van organisatie en uitvoering van de ingezette maatregelen weergegeven (doelmatigheid cluster Concurrentiekracht). Ook als bijvangst is in bijlage 7 input geleverd voor de beantwoording van algemene evaluatievragen van de EU, relevant voor de eindevaluatie POP3. De evaluatie per maatregel is in hoofdstuk 2 tot en met 5 beschreven. 


\section{$1 \quad$ Inleiding}

\section{$1.1 \quad$ Aanleiding}

Het Plattelandsontwikkelingsprogramma 2014-2020 (POP3) beoogt de innovatie en een duurzame modernisering van de agrarische sector te bevorderen. Het programma wordt zowel tijdens de looptijd als na afloop geëvalueerd. In 2019 dient Nederland aan de Europese Commissie te rapporteren over de voortgang van het POP3. In de tussenevaluatie POP3 komen de verschillende clusters aan maatregelen uit het POP3 aan bod. Dit rapport is gericht op het cluster Concurrentiekracht. Inzicht is gevraagd in de voortgang van de volgende vier maatregelen uit het cluster Concurrentiekracht:

- Maatregel 3 Kwaliteitsregeling Kalveren

- Maatregel 4.1.1. Productieve fysieke investeringen

- Maatregel 4.1.2. Jonge landbouwers-regeling (JoLa)

- Maatregel 4.3 Verbetering verkaveling

Maatregel 17 Brede weersverzekering is ook onderdeel van het cluster Concurrentiekracht. De maatregel wordt niet geëvalueerd in dit onderzoek, omdat in 2016 al een evaluatie heeft plaatsgevonden (Berkhout et al., 2016).

Onder de maatregel Productieve fysieke Investeringen worden ook meegenomen de regelingen:

- Fysieke investeringen voor innovatie en modernisering van agrarische ondernemingen Veenkoloniën

- Fysieke investeringen voor industriële verwerking van agrarische producten (zetmeelaardappelen) Veenkoloniën

- Fysieke investeringen Vleeskalveren.

Onder de maatregel Verbetering verkaveling vallen ook de regelingen verplaatsingen van glastuinbouwbedrijven.

\subsection{Doelstelling}

De maatregelen die in dit onderzoek worden geëvalueerd, vallen binnen POP3 onder het doel 3.2: het versterken van de agrarische bedrijfsstructuur. Het programma bestaat uit het ondersteunen en daarmee stimuleren van duurzame investeringen in het bedrijf (materieel) en infrastructuur (verkaveling), een kwaliteitsregeling Kalveren en de brede weersverzekering. Ten aanzien van de materiële investeringen vindt ook specifiek steun plaats aan jonge agrariërs via een lijst met duurzame investeringen. Alleen bovenwettelijke investeringen worden binnen het POP3 ondersteund.

De versterking van de agrarische structuur kan een belangrijke bijdrage leveren aan een verbetering van de inkomenspositie van agrarische ondernemers, de verduurzaming van het bedrijfsproces en daarmee aan de concurrentiepositie van agrarische sectoren en Nederland. Daarnaast wordt getracht hiermee een bijdrage te leveren aan de natuur- en milieudoelstellingen van zowel de Rijksoverheid als lokale overheden.

Deze tussenevaluatie heeft als doel inzicht te geven in het bereik en gerealiseerde (en te verwachten) effecten van ingezette middelen via maatregelen onder het cluster Concurrentiekracht. 


\subsection{Onderzoeksvragen en aanpak}

\section{Doelbereik}

Wat is de mate van bereik van de vooraf gestelde streefwaarden van de output- en resultaatindicatoren? Hierbij wordt als basis gebruikgemaakt van de beschikbare gegevens die RVO vastlegt en verstrekt. Ook kan aanvullend (kwantitatieve) informatie van provincies en Regiebureau POP worden gebruikt

\section{Beantwoording onderzoeksvragen}

Bij het evalueren van het cluster Concurrentiekracht wordt zowel een antwoord gegeven op een aantal specifieke vragen (per maatregel en voor het cluster) evenals op enkele relevante algemene vragen. $\mathrm{Bij}$ de algemene vragen betreft het de bijdrage van een maatregel aan de algemene doelen die beoogd worden met POP3. ${ }^{1}$

\section{Evaluatievragen}

De specifieke vragen binnen het cluster Concurrentiekracht zijn:

- In hoeverre hebben steunmaatregelen in het kader van het POP bijgedragen aan het verbeteren van de economische prestaties, de herstructurering en modernisering van ondersteunde landbouwbedrijven, met name door hun marktdeelname en landbouwdiversifiëring te verhogen?

- In hoeverre hebben de steunmaatregelen in het kader van het POP de generatiewissel in de landbouwsector ondersteund? Een instap van goedgeschoolde landbouwers op een andere wijze dan via generatiewisseling is niet meegenomen in deze evaluatie.

De algemene vragen die een duidelijke relatie hebben met de 4 ingezette maatregelen onder het cluster Concurrentiekracht, zijn:

- De GLB-doelstelling om het concurrentievermogen van de landbouw te bevorderen

- Het bevorderen van innovatie in de agrarische sector

- De GLB-doelstelling om duurzaam beheer van natuurlijke hulpbronnen en klimaatactie te waarborgen

De volgende algemene doelen zullen naar verwachting niet of nauwelijks beïnvloed worden door de inzet van middelen maatregel 4. Indien er wel een direct verband is, zal dit bij de specifieke maatregel worden behandeld.

- De GLB-doelstelling om een evenwichtige territoriale ontwikkeling van plattelandseconomieën en gemeenschappen te realiseren, onder meer door het scheppen en behouden van werkgelegenheid

- De Europa 2020-kerndoelstelling om aantal Europeanen dat onder armoedegrens leeft te verlagen

- Verbetering van het milieu en verwezenlijking van de EU-biodiversiteitsstrategiedoel-stelling om het biodiversiteit verlies en de achteruitgang van ecosysteemdiensten een halt toe te roepen en ze te herstellen

- Matiging van en aanpassing aan de klimaatverandering en verwezenlijking van de Europa 2020kerndoelstelling om de broeikasgasemissies met ten minste $20 \%$ te verlagen ten opzichte van de niveaus van 1990, of met $30 \%$ als de omstandigheden juist zijn, om het aandeel hernieuwbare energie in het finale energieverbruik met $20 \%$ te verhogen en de energie-efficiëntie met $20 \%$ te doen stijgen?

In deze tussenevaluatie is, naast het gebruikmaken van de beschikbare kwantitatieve informatie van RVO, provincies en Regiebureau POP, veel gebruikgemaakt van interviews en twee uitgevoerde representatieve enquêtes. Deze kenden een goede respons (tussen de 35 en 40\%). Binnen de omvang van dit onderzoek is de enquête beperkt tot subsidieontvangers, en is geen enquête gehouden onder ondernemers de geen aanvraag hebben gedaan, of waarvan de aanvraag is afgewezen. Diepte-interviews zijn gehouden onder subsidieadviseurs, accountantsbureaus, banken, NAJK- en POP3-coördinatoren provincies voor de maatregelen JoLa en productieve fysieke investeringen. Voor de maatregel Verbetering verkaveling zijn meerdere verkavelingsbureaus en beleidsmedewerkers provincies (veelal ook POP3-coördinatoren) geïnterviewd. Op deze wijze is de deskstudie en de expertise van het onderzoeksteam aangevuld.

\footnotetext{
1 Het betreft hier een tussenevaluatie 2014-2018 met een late opstart van openstellingen. De beantwoording van de algemene vragen heeft in dit onderzoek dan ook vooral het karakter van bijvangst, belangrijk ook voor de uiteindelijke expostevaluatie POP3.
} 
POP3 had in Nederland een moeilijke opstart. Het programma is pas begin 2015 goedgekeurd door de Europese Commissie. In 2015 is door Rijk en provincies veel aandacht besteed aan de uitvoeringsprocedures. Pas eind 2015 zijn de eerste openstellingen binnen het cluster Concurrentiekracht uitgezet, onder andere in de provincie Noord-Brabant. Mede gezien de trage opstart, en daarmee vooral openstellingen in 2016 tot en met 2018 is het moeilijk al meetbare resultaten (effecten) te verkrijgen voor deze tussenevaluatie, en een goed onderbouwde beoordeling te doen over de doeltreffendheid van de maatregelen. Er is dan ook vooral aangegeven wat op basis van de verworven informatie in dit onderzoek, voor de komende jaren mag worden verwacht.

In overleg met de opdrachtgever is ervoor gekozen ook de bijvangst uit interviews, enquêtes en deskresearch rond de doelmatigheid van de maatregelen (als derde aspect naast het bereik en doeltreffendheid van een maatregel) mee te nemen, inclusief aanbevelingen vanuit de praktijk rond de uitvoering.

\subsection{Opbouw van het rapport}

In de volgende 4 hoofdstukken worden per te evalueren maatregel de volgende aspecten behandeld:

- beleidstheorie: inhoud regeling, beoogde doelgroep en beoogde effecten

- bereik van de regeling: Data-analyse op basis van kwantitatieve beschikbare informatie (met name van RVO (aantallen, budget)

- doeltreffendheid: in hoeverre worden de vooraf gestelde doelen (streefwaarden) ook daadwerkelijk gerealiseerd? Indien mogelijk vindt dit plaats op basis van beschikbare kwantitatieve informatie, anderzijds op basis van kwalitatieve informatie (interviews, enquêtes, overige bronnen)

- doelmatigheid: het proces rond de organisatie en uitvoering van de maatregelen

- conclusies, aanbevelingen (vanuit de geleerde lessen in de periode 2014-2018).

In de bijlagen wordt nadere informatie verstrekt over onder andere:

- de vleeskalverenbedrijven (bijlage 1)

- resultaten van de enquêtes fysieke investeringen (bijlage 2) en JoLa (bijlage 3), als aanvulling op hoofdtekst

- verkaveling en verplaatsingsbesluit glastuinbouw Gelderland (bijlage 4)

- de begroting (budget) per maatregel, bij start programma en voorstel tot wijziging begroting per 31 december 2018); bijlage 5

- belangrijkste resultaten evaluatie Brede weersverzekering (bijlage 6)

- bijvangst voor beantwoording algemene vragen EU. 


\section{Kwaliteitsregeling Kalveren (maatregel 3)}

Belangrijkste bevindingen

- Eind 2018 bedraagt het totaal aantal goedgekeurde aanvragen voor de kwaliteitsregeling Vitaal Kalf 1.729. Dit is meer dan de streefwaarde van 1.700 bedrijven. Met dit aantal bedrijven is $100 \%$ van de Nederlandse vleeskalverenbedrijven bereikt;

- Het totale toegekende bedrag eind 2018 kwam uit op $€ 25,8 \mathrm{mln}$., ofwel $86 \%$ van het begrote bedrag van $€ 30 \mathrm{mln}$.

- Directe effecten zijn nog niet meetbaar omdat de regeling pas in 2017 en 2018 is opengesteld. De algemene verwachting is dat deelname aan de regeling een positief effect heeft op de gezondheid van vleeskalveren, en daarmee ook op uitval en antibioticagebruik.

- Lagere kosten voor uitval en antibiotica, en mogelijk ook betere groei en voerconversie zullen leiden tot lagere productiekosten. Ook kan een goede kwaliteitsregeling de positie van de kalversector op internationale afzetmarkten versterken.

- Op basis van bovenstaande mag een positief inkomenseffect worden verwacht. In welke omvang, is vooral afhankelijk van de ontwikkeling van contractprijzen.

\section{$2.1 \quad$ Beleidstheorie}

Door veranderingen in het GLB ontvangen vleeskalverenhouders vanaf 2014 alleen nog een toeslag per hectare. Dit is een aanzienlijk lager bedrag dan onder het vorige GLB (directe inkomenssteun via premies). Nederland heeft ter compensatie ervoor gekozen om de sector te ondersteunen met middelen vanuit POP3. Na een moeizaam proces (wat wil de sector, wat is er mogelijk binnen POP3, en een langdurige goedkeuringsprocedure EC) is de kwaliteitsregeling Kalveren opgesteld. Dit is een soort upgrade van het bestaande kwaliteitskeurmerk IKB Kalf naar Vitaal Kalf met als belangrijke aandachtspunten verbetering van de gezondheid of vitaliteit van kalveren (onder andere een vermindering van het gebruik van antibiotica) en het ontwikkelen van een beter volgsysteem ter versterking van de (samenwerking in de) keten. Met deze regeling wordt beoogd de sector verder te verduurzamen, en te komen tot een meer maatschappelijk verantwoord producerende sector. Productie met certificering Vitaal Kalf kan leiden tot lagere bedrijfskosten door vitaal betere kalveren, en mogelijk hogere kalverprijzen (door het verwaarden van duurzamer geproduceerd vlees) en dus een beter inkomen voor ondernemers, als een versterking vaan de concurrentiepositie van de sector.

Deelname aan kwaliteitsregelingen brengt extra kosten met zich mee, zoals in de productiewijze, certificeringseisen en toezicht daarop. Kalverhouders die voor het eerst deelnemen aan deze erkende vrijwillige certificeringsregeling Vitaal Kalf voor de productie van kalfsvlees kunnen compensatie van de certificerings- en auditkosten verkrijgen via het aanvragen van de POP3-subsidie kwaliteitsregeling Kalveren. In zowel 2017 als in 2018 is er een openstelling geweest. De aanwezigheid van een certificaat Vitaal Kalf is een voorwaarde om voor een subsidie uit de POP3-maatregel kwaliteitsregeling Kalveren in aanmerking te komen (een ingangscontrole vindt plaats via SKV). Ieder jaar moet het certificaat verlengd worden, om ook de volgende jaren in aanmerking te komen voor subsidie (jaarlijkse controle door SKV). 
Vitaal Kalf

Het doel van de certificeringsregeling Vitaal Kalf is de verbetering van de vitaliteit van kalveren door de hele keten heen, te beginnen bij de melkveehouders. Vitale kalveren zijn gezonde kalveren, die niet te jong zijn en niet te licht zijn.

Om de vitaliteit van kalveren te verbeteren zijn in het kader van Vitaal Kalf deels ook voorschriften bij de verzamelcentra neergelegd. $\mathrm{Er}$ is een kalfvolgsysteem ontwikkeld, en de registratie daarin is begin 2019 zo goed als rond. In de toekomst wil de kalversector ook informatie van slachterijen (over slachtgewicht en classificatie) gaan terugkoppelen naar de voorschakels in de keten.

Verder bevat Vitaal Kalf een heel aantal wettelijke en bovenwettelijke eisen op het gebied van diergezondheid en dierenwelzijn. Kalverhouders moeten de waterkwaliteit bemonsteren in het zogenaamde koud watervat (bacteriologisch en chemisch) en aan het einde van de drinkwaterleidingen (bacteriologisch). Het bemonsteren van de waterkwaliteit bij gebruik van een eigen bron was al een IKBverplichting.

Naast de algemene verbetering van de vitaliteit is er gerichte aandacht voor met name Bovine Virus Diarree (BVD-)bestrijding. De zuivelsector is hier in april 2018 mee begonnen, maar nog lang niet alle melkveebedrijven zijn nu al BVD-vrij. In april 2020 zullen BVD-maatregelen worden opgenomen in Vitaal Kalf en zal de kalversector alleen nog BVD-vrije kalveren afnemen. ${ }^{2}$

In het kader van de beoogde verbeteringen is er ook meer communicatie geweest (nieuwsbrieven) en meer aandacht voor diergezondheidsissues. De sector probeert ook de kennis van de kalverhouder te vergroten, los van de kwaliteitsregeling, maar ook primair gericht op een betere diergezondheid. ${ }^{3}$

Onder de kwaliteitsregeling Kalveren vallen ook activiteiten op het gebied van voorlichting en afzetbevordering. Dit onderdeel van de maatregel valt buiten deze evaluatie

\section{$2.2 \quad$ Bereik}

Het totale aantal aanvragen kwaliteitsregeling Kalveren dat is goedgekeurd bedroeg in 20171.698 en in 201831 (figuur 2.1). Daarmee is $100 \%$ van de Nederlandse vleeskalverenbedrijven bereikt. Eind 2016 waren er 1.257 gespecialiseerde vleeskalverenbedrijven en 434 niet-gespecialiseerde bedrijven met vleeskalveren (Bron: Landbouwtelling). ${ }^{4}$ De vooraf gestelde streefwaarde van 1.700 bedrijven is eind 2018 al bereikt. $^{5}$

De betalingsverplichting was in $2017 € 15.000$ per goedgekeurde aanvraag. Bedrijven ontvangen over de periode 2017 tot en met $2021 € 3.000$ per jaar. Bij een goedgekeurde aanvraag in 2018 wordt nog $€ 12.000$ ontvangen (voor de periode 2018 tot en met $2021 € 3.000$ per jaar). Bedrijven die minder gespecialiseerd zijn - minder dan 50 vleeskalveren - ontvangen jaarlijks een lager bedrag. Het totale toegekende bedrag eind 2018 kwam uit op $€ 25,8 \mathrm{mln}$. (bron: RVO). Het begrote bedrag voor de gehele POP3-periode bedraagt $€ 30 \mathrm{mln}$. $\mathrm{Er}$ is dus $86 \%$ van het begrote bedrag toegekend. Het merendeel van het aantal goedgekeurde aanvragen tot en met 2018 (figuur 2.1. naar provincie) komt uit de provincie Gelderland (43\%) gevolgd door Noord-Brabant en Overijssel.

\footnotetext{
2 Overigens zijn nog maar weinig landen BVD-vrij ten aanzien van kalveren (bron: https://www.ibrbvd.nl/bvd/over-bvd. Een belangrijk deel van de kalveren wordt geïmporteerd.

3 Hiervoor is een e-learning-tool ontwikkeld met de naam 'e-Veal'. Ten slotte zullen er de komende twee jaar bijeenkomsten met kalverhouders worden belegd over de optimale opvang van kalveren op het kalverbedrijf. Dat gaat hopelijk ook leiden tot verdere verbetering van de diergezondheid.

${ }^{4}$ Eind 2017 waren er 948.000 vleeskalveren in Nederland (354.000 voor de rosékalfsvleesproductie; 594.000 voor blankvleesproductie). Bron: Landbouwtelling.

5 In de planning staat nog een openstelling 2019 voor vleeskalveren op nevenbedrijven.
} 


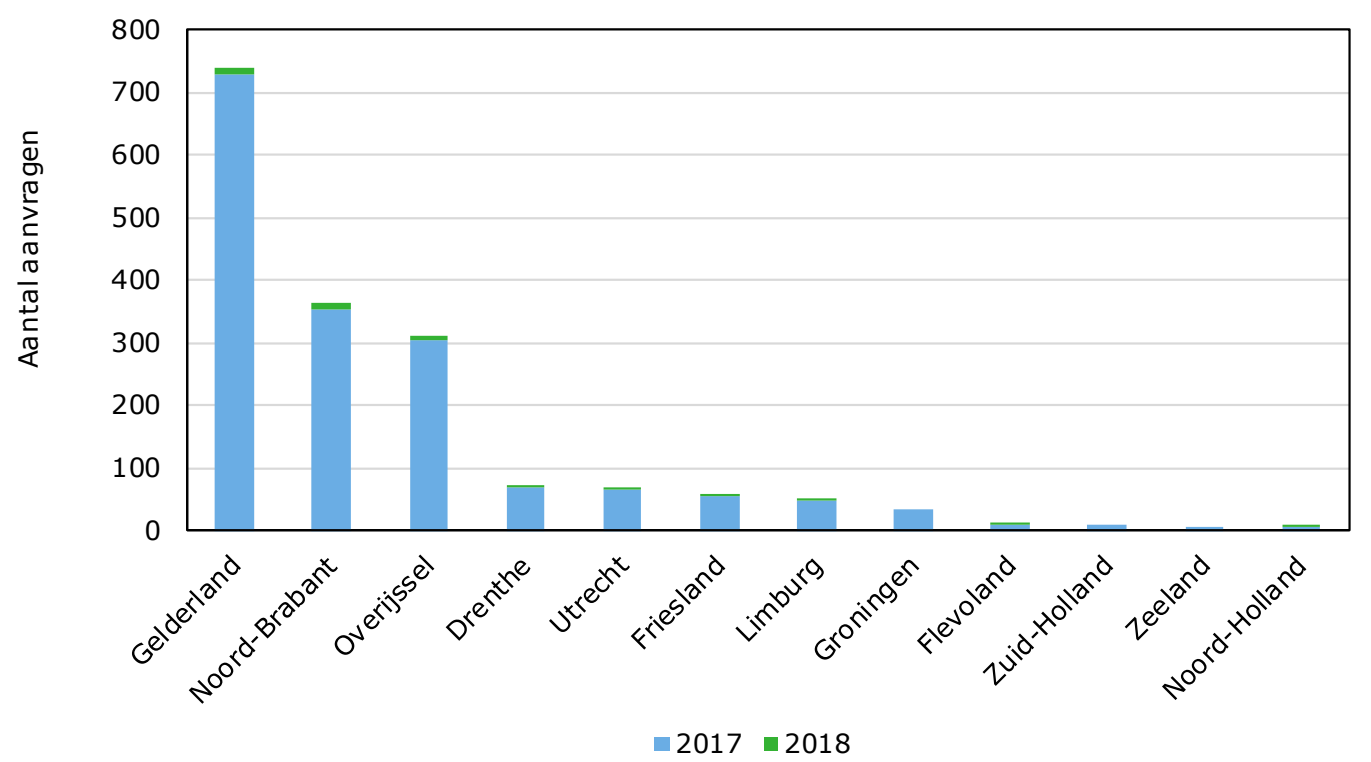

Figuur 2.1 Aantal goedgekeurde aanvragen per provincie per jaar van goedkeuring kwaliteitsregeling Kalveren (deelname aan Vitaal Kalf)

\subsection{Doeltreffendheid}

Effecten op gezondheid van de kalveren

Het is nog niet mogelijk om op basis van cijfers te beoordelen of de beoogde doelen worden behaald. Cijfers over 2018 zijn er nog niet. De geïnterviewde experts hebben de indruk dat de beoordeling of kalveren 14 dagen oud zijn, op basis van de melddatum van het kalf in I\&R, een behoorlijk positief effect heeft op de gezondheid van de kalveren. Dit is overigens nog niet hard te maken in de cijfers over bijvoorbeeld uitval en antibioticagebruik. Momenteel is de gemiddelde kalversterfte op de kalverbedrijven ongeveer $4 \%$, in de melkveehouderij ligt dat met ongeveer 12 à $13 \%$ op een hoger niveau. ${ }^{6}$

De melkveehouderij is ook zelf meer aandacht gaan besteden aan de kalver-opfok, in het kader van het Plan van Aanpak Vitaal, gezond en duurzaam kalf. De deskundigen verwachten ook daarvan belangrijke positieve effecten op de kwaliteit van de kalveren in de melkveesector. Dat is van belang voor de kalversector, en eveneens een voordeel voor melkveebedrijven zelf, voor de kalveren die ze wel aanhouden.

Effecten op inkomens en concurrentievermogen van de kalversector?

Vitaal Kalf richt zich vooral op het verminderen van gezondheidsproblemen en op deze wijze verduurzaming van het productieproces. Een aantal redelijk direct te verwachten effecten van deze regeling zijn: minder kosten voor uitval, minder kosten voor antibiotica, mogelijk ook betere groei en voerconversie. Dit zal leiden tot lagere productiekosten, en dit kan leiden tot een positief effect op de inkomens van vleeskalverenhouders. Dit effect is sterk afhankelijk van de ontwikkeling van de contractprijzen. De regie in de keten ligt vooral bij een enkele partij, met grote invloed op de hele keten. Ongeveer 75 à $80 \%$ van de vleeskalverenhouders werkt op contractbasis. Het gemiddelde inkomen op deze bedrijven schommelde de afgelopen vier jaren nauwelijks (Agrimatie.nl).

Ook relevant, maar meer indirect zijn de voordelen in de markt. De verbetering van kwaliteitsregelingen kan zeker bijdragen aan het positieve imago van kalfsvlees. Nederlandse partijen hebben de afgelopen jaren actief moeten zoeken naar nieuwe afzetmarkten, en die noodzaak is nog altijd relevant. De afzet in Nederland is beperkt, $90 \%$ van het kalfsvlees wordt geëxporteerd, vooral naar

${ }^{6}$ Bronnen: https://www. boerderij. nl/Rundveehouderij/Blogs/2019/4/Met-meer-tijd-minder-uitval-bij-kalveren-411757E/; KWIN Veehouderij 2018/2019. 
Italië, Duitsland en Frankrijk. Het verwaarden van het kalfsvlees, een product dat relatief al een hoge prijs heeft, gebeurt vooral via een sterke ketenpartij (ketenregisseur) die daarbij streeft naar een uniform kwaliteitsproduct. Een duurzamer geproduceerd product kan de concurrentiepositie van de Nederlandse sector op termijn versterken.

Gezien de nog maar korte invoering van Vitaal Kalf is het inkomenseffect eind 2018 nog niet meetbaar. Het meedoen aan Vitaal Kalf wordt ook (nog) ervaren als een 'licence to produce', als een soort verplichting vanuit markt en overheid. Zo kunnen huidige bovenwettelijke verplichtingen in de nabije toekomst een wettelijk karakter krijgen.

Zowel het meedoen aan Vitaal Kalf (licence to produce), een sterkere verbinding in de keten door een goed volgsysteem, als moderniseringsinvesteringen kunnen als positieve prikkels worden gezien voor potentiele opvolgers ervoor te gaan. Ondanks een mogelijke productiekostenverlaging zal uiteindelijk het inkomenseffect voor bedrijven (die voor $75 \%$ op contractbasis werken, met inbreng van gebouwen, arbeid en verwerking mest) vooral bepaald worden door contractprijzen. In hoeverre een mogelijk betere verwaarding van een beter kwaliteitsproduct doorberekend zal worden in contracten is op voorhand niet te zeggen.

Een bijkomend voordeel van het opzetten van een goed volgsysteem (binnen Vitaal Kalf) is dat ketenpartijen meer informatie/kennis met elkaar hebben gedeeld en mogelijk blijven delen.

Een modernisering van de kalverenbedrijven is eerder te verwachten via de specifiek voor de sector kalverhouderij opgenomen maatregel Fysieke investeringen. Het betreft investeringen gericht op verduurzaming via welzijnsvriendelijke vloeren en ammoniak-reducerende systemen, met een eerste openstelling eind 2018 (zie paragraaf 3.1).

Tabel 2.1 Bijdrage maatregel Kwaliteitsregeling Kalveren aan algemene evaluatievragen EU (bijvangst, zie ook bijlage 7)

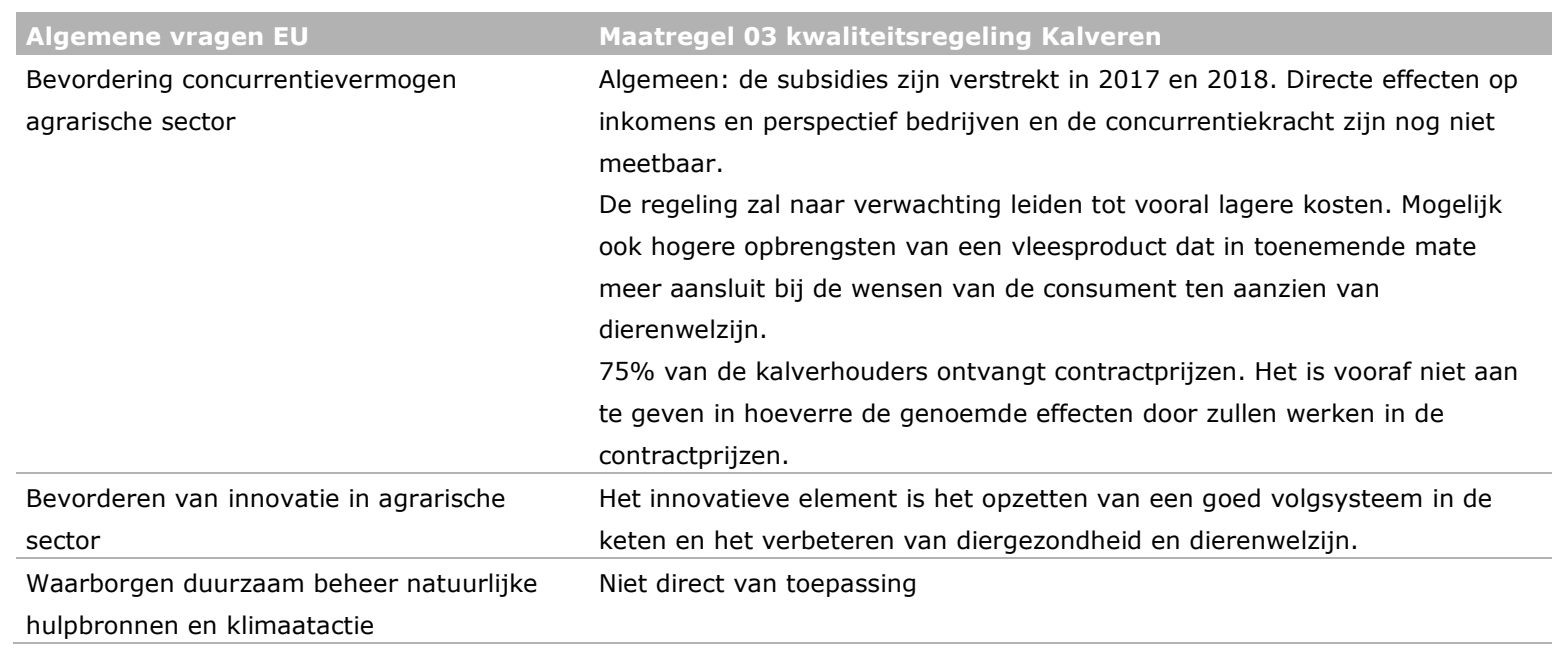

\subsection{Doelmatigheid}

Vitaal Kalf is een compleet nieuw kwaliteitssysteem: het hele pakket kost iets meer dan $€ 6,7$ mln. per jaar (in 2018) (bron: SBK). In het verleden waren er uiteraard ook al kosten voor de toenmalige IKBregeling. De kosten voor IKB-SKV bedroegen ongeveer $€ 2,50$ per kalf. 
Bij de kosten van Vitaal Kalf gaat het om a) Audits en Certificering, b) Classificatie en c) Analyse. ${ }^{7}$ Alleen de kosten onder a) audits en certificering vallen onder de kwaliteitsregeling Kalveren. ${ }^{8}$ Dit betreft onder andere de personeelskosten, reis- en verblijfskosten, materiaalkosten, automatiseringskosten, etc. ten behoeve van de uitvoering van audits en certificeringswerkzaamheden voor Vitaal Kalf.

Bij alle kalverbedrijven is er minimaal eens per jaar een audit. De bemonsterings- en analyseactiviteiten worden willekeurig verdeeld over de bedrijven. Omdat een groot deel van de activiteiten willekeurig gebeurt is ervoor gekozen om voor alle bedrijven met meer dan 50 kalveren een gelijke bijdrage vast te stellen. Voor de kleinere bedrijven zijn staffels ingesteld omdat voor die bedrijven de inspanningen substantieel minder zijn. Dit betreft overigens maar een zeer klein deel van de totale populatie aan bedrijven.

\section{Is de subsidie kostendekkend?}

Door de POP3-regeling krijgen de kalverhouders hun deelname aan Vitaal Kalf gedurende maximaal 5 jaar (bij goedgekeurde aanvraag in 2017) of 4 jaar (bij goedgekeurde aanvraag in 2018) vergoed. De grootste voordelen (kostenbesparingen) zijn te realiseren doordat de verbetering van de diergezondheid op sectorschaal wordt aangepakt.

De subsidie vergoedt niet de kosten voor de analyse van watermonsters ( $€ 100$ à 150 per bedrijf per jaar, als ruwe indicatie). Verder zit ook de monitoring op verboden stoffen in de kosten van deelname aan Vitaal Kalf, maar die monitoring wordt niet aan de kalverhouders zelf overgelaten. Sommige kalverhouders hebben voor hun deelname aan Vitaal Kalf moeten investeren in een hygiënesluis, of in een verbetering daarvan.

\subsection{Conclusies en aanbevelingen}

\section{Conclusies}

De kwaliteitsregeling Kalveren, met deelname aan Vitaal Kalf, zal naar verwachting een positief effect hebben op de gezondheid van vleeskalveren, en daarmee ook op uitval en antibioticagebruik. Lagere kosten voor uitval en antibiotica, en mogelijk ook betere groei en voerconversie zullen leiden tot lagere productiekosten. Ook kan een goede kwaliteitsregeling de positie van de kalversector op internationale afzetmarkten versterken.

Het is dus goed mogelijk dat bovenstaande effecten op termijn tot een verbetering van de inkomenspositie kunnen leiden, een positie die overigens al meerdere jaren vrij stabiel van karakter is. De te verwachten inkomensontwikkeling is in deze sector sterk afhankelijk van de ontwikkeling van contractprijzen. Gezien ook de nog korte tijd dat Vitaal Kalf bestaat, is nog niet aan te geven hoe de toekomstige inkomensontwikkeling voor deze agrarische ondernemers zal uitpakken.

\section{Aanbevelingen}

Analyseer over een of twee jaar een aantal indicatoren voor vitaliteit van kalveren, zoals uitval en antibioticagebruik, om de verwachte positieve effecten met cijfers te onderbouwen. Ook zal verder gewerkt worden aan terugkoppeling van gezondheidsinformatie in de keten, onder andere naar melkveehouders. Bekijk over enkele jaren hoe deze informatieverstrekking functioneert, welke ervaringen de veehouders hebben en wat de effecten zijn op de kalvergezondheid op zowel melkveeals kalverbedrijven.

\footnotetext{
7 Ad b) Dit betreft de classificatiewerkzaamheden voortvloeiend uit Vitaal Kalf-voorschriften, uitgevoerd door CBS (uitbesteding van SKV aan CBS);

Ad c) Dit betreft de analysewerkzaamheden voortvloeiend uit Vitaal Kalf-voorschriften, uitgevoerd door TNO Ducares (uitbesteding van SKV aan TNO Ducares).

8 De meeste kalverbedrijven betalen $€ 3.000$ per jaar voor hun deelname aan Vitaal Kalf voor de audits en de certificering. Dit leverde in 2018 ongeveer in totaal $€ 4,9 \mathrm{mln}$. op. Deze inkomsten dekken niet de volledige kosten voor de uitvoering van Vitaal Kalf. De aanvullende kosten van circa $€ 1,8 \mathrm{mln}$. worden grotendeels bijgedragen door de bij SKV aangesloten slachterijen en de eigenaren van de dieren (deels zijn dat ook kalverhouders). Bron: SBK, persoonlijke mededeling.
} 


\section{Productieve fysieke investeringen (maatregel 4.1.1)}

Belangrijkste bevindingen ${ }^{9}$

- In de periode 2016 tot en met 2018 is voor ruim $€ 38 \mathrm{mln}$. subsidie toegekend in het kader van de maatregel Productieve fysieke investeringen. Dit is $37 \%$ van het begrote bedrag ter waarde van bijna $104 \mathrm{mln}$. Hier staat tegenover dat aanvragen ter waarde van bijna $€ 63 \mathrm{mln}$. zijn afgewezen, voornamelijk als gevolg van overtekening van beschikbare budget. Afwijzing wordt door de indieners demotiverend ervaren

- Gemiddeld is het verleende bedrag per aanvraag in bijna $€ 100.000$.

- In totaal zijn er 397 aanvragen goedgekeurd: in 2016 51, in 2017179 en in 2018167.

- $80 \%$ van de aanvragers met een goedkeuring vindt de gesubsidieerde investering goed aansluiten bij de persoonlijke investeringsbehoefte. Ook $80 \%$ vindt dat de regeling een duidelijke meerwaarde heeft. Velen geven aan dat veel van deze bovenwettelijke investeringen in deze vorm zonder subsidie niet zouden zijn uitgevoerd. Met name in de akkerbouw heeft de regeling bijgedragen aan het versnellen van een investering.

- De investeringen uitgevoerd in het kader van de regeling hebben een groot effect op de duurzaamheid, en modernisering van het bedrijf.

- Het effect van de regeling op het verbeteren van de economische prestaties zal in de meeste gevallen nog beperkt zijn. Het effect van de investering zal vooral een verlaging van de productiekosten zijn. Gezien de vrij late openstellingen (sinds eind 2015) en ook investeringen met een uitvoertermijn van 2-3 jaar, zijn nog geen harde inkomenseffecten meetbaar.

- Vanuit meerdere provincies wordt de regeling gezien als maatwerk voor uitvoering van beleidsdoelen. De ervaringen met open inschrijvingen lopen uiteen, sommige provincies gebruiken investeringslijsten, of zijn erop overgegaan.

- De specifieke regeling Productieve fysieke investeringen Innovatie en modernisering Veenkoloniën heeft tot en met 201848 ondernemers subsidie voor apparatuur verstrekt. Dit zal op deze bedrijven leiden tot modernisering en verduurzaming van het productieproces. Door openstellingen in 2017 en 2018 zijn er geen inkomenseffecten meetbaar. De investeringslijst is in goede harmonie met de sector samengesteld.

Aanbevelingen

- Continueer de huidige maatregel Productieve fysieke investeringen, maar streef naar meer harmonisatie in de uitvoering, samenwerking tussen provincies in het gelijk trekken van investeringsmogelijkheden en openstelling.

- Probeer een systematiek aan te houden waarbij het \% afgewezen aanvragen wordt beperkt.

- Probeer in de opeenvolgende openstellingen te variëren in investeringen, zodat meerdere sectoren gedurende de POP-periode aan bod komen. In sommige provincies gebeurt dit al.

\subsection{Beleidstheorie}

Onder deze maatregel 4.1.1. valt steun voor de fysieke investeringen in innovaties en modernisering van agrarische ondernemingen. Het doel is landbouwers te ondersteunen om te investeren in ontwikkelingen die economisch rendement combineren met maatschappelijke doelen, zoals het leveren van een bijdrage aan verbetering van het milieu, klimaatbestendigheid, dierenwelzijn, volksen diergezondheid, landschap of biodiversiteit.

Deze maatregel is ook bedoeld voor steun aan de eerste toepassing van nieuwe technieken en aan investeringen in de toepassing van innovatieve technieken, processen of producten. Agrarische

\footnotetext{
${ }^{9}$ De specifieke regelingen fysieke investeringen in diervriendelijke vloeren en in ammoniakbeperkende apparatuur in de vleeskalverhouderij zullen naar verwachting een impuls geven aan verdere verduurzaming van het productieproces. Eind 2018 waren er echter nog geen goedkeuringen van de aanvragen in 2018.
} 
ondernemers worden ondersteund om op deze wijze duurzamer te werken en nieuwe verdienmogelijkheden te creëren.

Elke provincie bepaalt zelf of en wanneer deze regeling wordt opengesteld en onder welke voorwaarden. Er zijn grote verschillen in wijze van openstelling tussen provincies. Provincies werken ofwel met investeringslijsten ofwel met open inschrijving, waarbij een adviescommissie van deskundigen een oordeel geeft: de commissie stelt een rangorde op afhankelijk van een score op selectiecriteria. Ook komt het voor dat hierbij gebruik wordt gemaakt van deskundige onderzoekers in combinatie met een adviescommissie.

Onder de regeling 'Fysieke investeringen voor innovatie en modernisering van agrarische ondernemingen' kan tot $40 \%$ subsidie worden verkregen op de subsidiabele kosten voor diverse investeringen. Veel projecten zijn gericht op bodemverbetering, nieuwe producten en markten en op verbetering van het rendement in combinatie met milieuvriendelijk werken.

Naast de algemene regeling is een aanvullende fysieke regeling opgesteld voor de vleeskalverhouderij en ook een voor de Veenkoloniën. In beide gevallen is gekozen deze sector of dit gebied specifiek te steunen ter compensatie van het verlies van directe premies door de overgang naar de flate rate in de verdeling van de directe GLB-betalingen.

\section{Vleeskalveren}

In POP3 is er $20 € \mathrm{mln}$. begroot onder maatregel 4 voor de sector vleeskalverhouderij. Er zijn een tweetal investeringssubsidies voor vleeskalverhouders, die eigenaar zijn van een of meer stallen waarin zij bedrijfsmatig vleeskalveren houden, te weten:

- Aanschaf en installatie van investeringen in diervriendelijke stalvloeren (nieuwe roostervloeren, of in-gefreesde bestaande roostervloeren)

- Aanschaf en installatie investeringen in nieuwe apparaten die de uitstoot van ammoniak verminderen. Het betreft systemen die op de RAV-lijst staan vermeld. Toedeling bij over- intekening gebeurt op basis van het percentage reductie. Maximum subsidiebedrag is $€ 100.000$ per vleeskalverhouder.

Met deze subsidie wordt een kwaliteitsimpuls beoogd voor de vleeskalversector door het stimuleren van innovatie, duurzaamheid en dierenwelzijn. Door de verstrekking van $40 \%$ subsidie (exclusief btw) en daarmee een beperking van de financieringslasten zullen bedrijven sneller overgaan tot het verrichten van deze investeringen die tot een duurzamere bedrijfsvoering leiden. Ook zal de regeling diervriendelijke stalvloeren een aansporing voor het bedrijfsleven (kunnen) zijn om de vloeren nog verder technisch te ontwikkelen, door een toenemende vraag.

\section{Veenkoloniën}

In POP3 is er voor de Veenkoloniën extra ondersteuning begroot. Dit is vooral een compensatie voor de zetmeelteelt voor het wegvallen van directe premies door veranderingen in de eerste pijler van het GLB. Een deel van de gereserveerde gelden voor fysieke investeringen valt onder maatregel 4 , naar schatting een $€ 6 \mathrm{mln}$.

In de periode tot en met 2018 zijn de volgende 2 openstellingen fysieke investeringen geweest:

- Fysieke investeringen voor innovatie en modernisering van agrarische ondernemingen Veenkoloniën, met een openstelling door de provincie Groningen in 2017);

- Fysieke investeringen voor industriële verwerking van agrarische producten (zetmeelaardappelen) Veenkoloniën 2018.

De cofinanciering wordt verzorgd door de provincies Groningen en Drenthe. Aanvragen voor deze subsidies zijn ingediend via de site van SNN. De uitvoering wordt verzorgd door het SNN en de Rijksdienst voor Ondernemend Nederland (RVO). 


\subsection{Bereik}

In de periode 2016 tot en met 2018 is voor ruim $€ 38 \mathrm{mln}$. subsidie toegekend in het kader van de maatregel Productieve fysieke investeringen. Dit is $37 \%$ van het begrote bedrag ter waarde van bijna $€ 104 \mathrm{mln}$. (zie ook bijlage 5). Overigens was er bij de start van POP3 een bedrag van $€ 117 \mathrm{mln}$. begroot voor de maatregel. In totaal zijn er 397 aanvragen goedgekeurd: in 2016 51, in 2017179 en in 2018 167).

Opvallend is dat er in de periode 2016 tot en met 2018 aanvragen ter waarde van bijna $€ 63 \mathrm{mln}$. zijn afgewezen. Belangrijkste verklaring hiervoor is het veelal zwaar over-intekenen ten opzichte van het beschikbare budget per openstelling. In totaal waren er dan ook 686 afwijzingen (34 in 2016, 370 in 2017 en 282).

Limburg is de provincie met het grootste bedrag aan verleende subsidies, namelijk ruim $€ 8 \mathrm{mln}$. (zie figuur 3.1). In meerdere provincies zijn er tot en met 2018 nog maar een beperkt aantal openstellingen geweest, zoals bijvoorbeeld de provincie Drenthe met 1 openstelling. In de provincies Zeeland en Friesland zijn tot en met 2018 geen goedgekeurde aanvragen verstrekt. Zeeland verwacht begin 2019 een aanzienlijk bedrag van een openstelling in 2018 goed te keuren, en zal met een nieuwe openstelling in 2019 komen. Ook de provincie Friesland is voornemens in 2019 tot openstelling over te gaan.

Bij invulling van de maatregel Productieve fysieke investeringen wordt sterk gestuurd op realisatie van provinciale beleidsdoelen. Het openstellingsbesluit geeft hiervoor ook de ruimte. Een belangrijk deel van de provincies zet de regeling als sturingsinstrument in om beleid te realiseren. Zo wordt in Groningen door middel van een investeringslijst sterk gestuurd op verduurzaming intensieve veehouderij en biologische landbouw.

De provincie Noord-Holland heeft bij de openstelling breed ingezet: inschrijving op meerdere beoogde doelen van de regeling was mogelijk (met hoge eisen ten aanzien van innovatie en duurzaamheid), dit via een open inschrijving, en met hoge minimum- en maximumbedragen. Dit heeft geleid tot budgettair grote projecten, zoals bijvoorbeeld investeringen in hele stallen of stalsystemen, selecteren van bloembollen, verwerkingsproces lokale melkfabriek. Het gemiddelde toekenningsbedrag in NoordHolland ( $€$ 350.000) komt daarmee op een veel hoger niveau uit dan het landelijke gemiddelde in

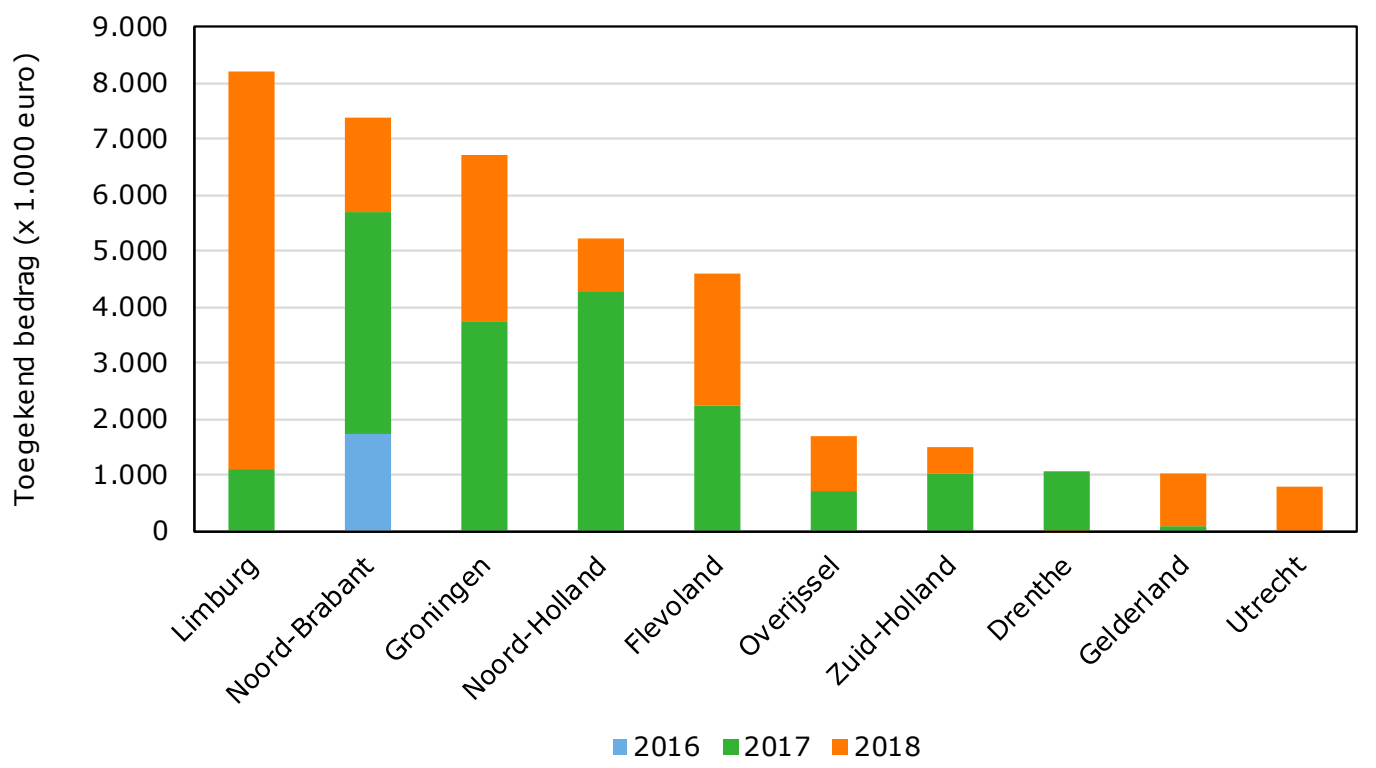

Figuur 3.1 Toegekend bedrag Investeringsregeling, periode 2016 tot en met 2018, naar provincie a) a) Opmerking: tot en met 2018 zijn er in de provincies Zeeland en Friesland geen aanvragen goedgekeurd

Bron: RVO, bewerking Wageningen Economic Research. 
de jaren 2016 tot en met 2018 (met een bedrag rond de $€ 95.000$, zie figuur 3.2 ). ${ }^{10,11}$

De provincies Drenthe en Gelderland bleven qua gemiddeld bedrag in deze jaren achter. De provincie Gelderland heeft in de loop van 2017 gekozen voor een koppeling aan het Deltaplan Agrarisch Waterbeheer (DAW), een gerichter systeem dan de eerdere open inschrijving. Overigens had ook Noord-Brabant in 2015 al een openstelling specifiek voor precisiebemesting geweest (ook in het kader van DAW). In Drenthe is er nadrukkelijk gekozen voor directe investeringen op het boerenerf. Dat type investering is in doorsnee beperkt qua financiële omvang.

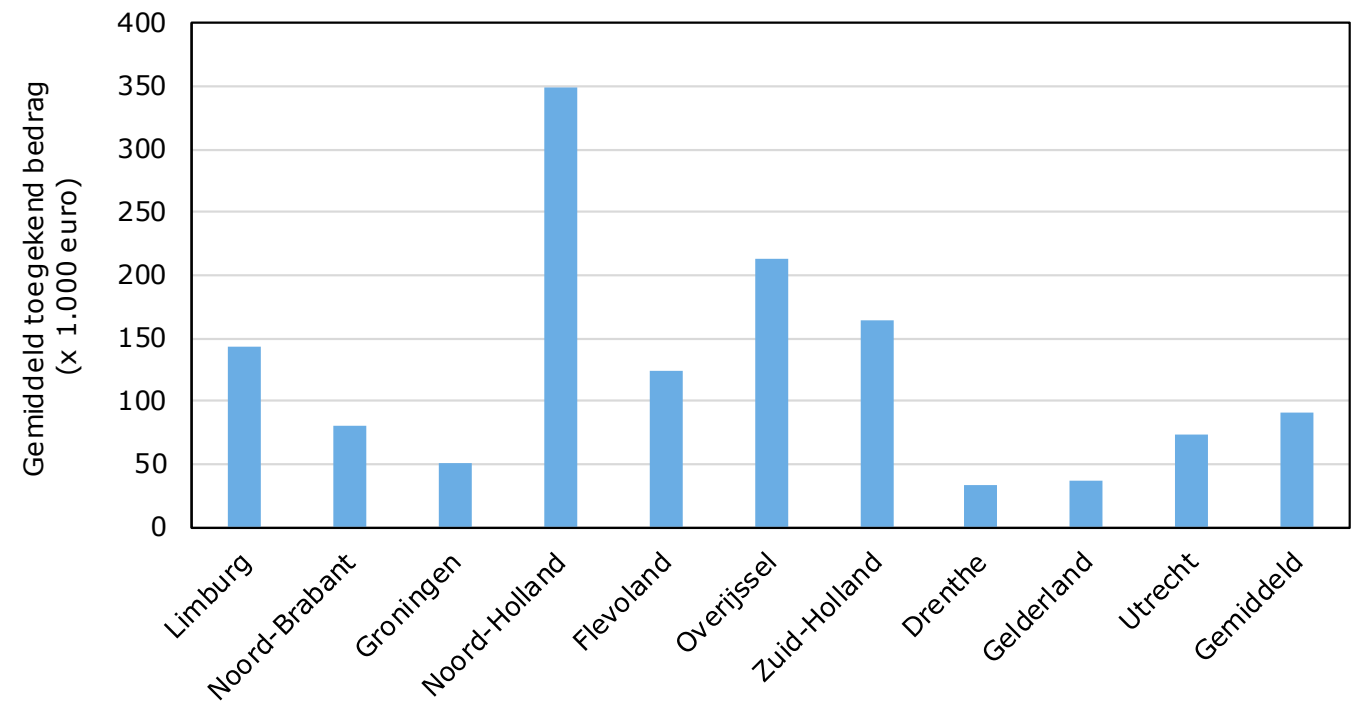

Figuur 3.2 Gemiddeld bedrag toegekende aanvragen ( $x € 1.000)$ onder Maatregel 0.4.1.1. Fysieke investeringen, per provincie, over periode 2016 tot en met 2018 a)

a) Tot en met 2018 is er in de provincies Zeeland en Friesland geen subsidie verstrekt.

De meeste projecten hebben meer dan 1 thema of beoogd doel, en zijn vooral in de akkerbouw en melkveehouderij te vinden.

\section{Vleeskalveren}

Er is in de POP3-begroting een budget van $€ 20 \mathrm{mln}$. gereserveerd voor de specifieke regeling fysieke investeringen vleeskalverhouderij. In totaal is in $2018 € 15 \mathrm{mln}$. beschikbaar gesteld voor openstelling van de beide regelingen in 2018 en 2019 (met een gelijke verdeling).

In 2018 zijn 154 aanvragen ingediend voor investeringen in diervriendelijke stalvloeren. Dit betekent dat ongeveer een kleine $10 \%$ van de bedrijven met vleeskalveren een aanvraag heeft ingediend. Gedurende deze tussenevaluatie kwam naar voren dat er in 2018 nog geen goedkeuringen door RVO hebben plaatsgevonden (maar in de eerste 4 maanden 2019) ${ }^{12}$ waardoor deze regeling verder niet in deze evaluatie op doeltreffendheid wordt beoordeeld. Hetzelfde is van toepassing voor de regeling ammoniakreductie. ${ }^{13}$ In 2018 zijn voor deze regeling 104 aanvragen ingediend.

\footnotetext{
${ }^{10}$ Noord-Holland heeft de strategische keuze gemaakt veel kleine investeringen specifiek voor individuele bedrijven ( 800 per 31-12-2018) buiten POP3 met andere instrumenteninzet te ondersteunen (dit in relatie tot de financiële POP3 afspraken in het kader van modulatie watergelden $1^{\mathrm{e}}$ pijler), met name gericht op bodem en water via het Landbouwportaal. Bovendien geldt dat veel kleine investeringen die provincies via investeringslijsten POP3 steunen ook al via MIA VAMIL worden ondersteund. Dit wordt door de provincie Noord-Holland minder effectief gevonden.

${ }^{11}$ Daarnaast heeft Noord-Holland, evenals meerdere andere provincies, koepelprojecten zoals bijvoorbeeld kavelruil $(3,2 \mathrm{mln}$.): dit telt als 1 project, maar kent veel begunstigde bedrijven. Ook de investering in lokale melkfabriek heeft betrekking op de concurrentiepositie van veel bij het project aangesloten melkveebedrijven, een project dus met een groter bereik.

12 Medio april 2019 zijn 99 aanvragen goedgekeurd (met een toegewezen bedrag van $€$ 6.965.216) en zijn nog 46 aanvragen in behandeling.

${ }^{13}$ Investeringen in ammoniakreductie: medio april 2019 zijn 61 aanvragen toegewezen voor totaalbedrag van $€$ 2.200.278.
} 


\section{Veenkoloniën}

Bereik regeling fysieke investeringen innovatie en modernisering Veenkoloniën 2017: In goede samenwerking vooraf met de ondernemers en bedrijven in de regio is een investeringslijst opgesteld om het machinepark op de agrarische bedrijven te moderniseren en tot een duurzamere op de toekomstgerichte bedrijfsvoering te komen. De belangstelling voor de regeling was met 191 bedrijven groot. Ongeveer eenzesde deel van de bedrijven deed een aanvraag, die in te passen is in hun investeringsritme om een deel van hun machinepark te moderniseren. Ongeveer $25 \%$ van de aanvragers heeft uiteindelijk subsidie ontvangen. Dat betekent ook 3 op de 4 bedrijven die een afkeuring heeft gekregen, met bijkomende kosten. In 2019 komt er een nieuwe openstelling voor deze regeling tot modernisering en verduurzaming machinepark met een beoogd budget van ongeveer $€ 4 \mathrm{mln}$. (meer dan het dubbele van de eerste openstelling).

Tabel 3.1 Overzicht aanvragen en toewijzingen specifieke regelingen voor de Veenkoloniën onder maatregel Productieve fysieke investeringen

\begin{tabular}{|c|c|c|c|c|}
\hline Openstelling & \#Aanvragen & $\begin{array}{l}\text { \#Toegewezen } \\
\text { per 31-12-2018 }\end{array}$ & $\begin{array}{l}\text { Aangevraagd } \\
\text { Bedrag }\end{array}$ & Toegewezen bedrag \\
\hline $\begin{array}{l}\text { Fysieke investeringen innovatie } \\
\text { en modernisering Veenkoloniën } \\
2017\end{array}$ & 191 & 48 & $€ 8.716 .100$ & $€ 1.838 .893$ \\
\hline $\begin{array}{l}\text { Fysieke investeringen industriële } \\
\text { verwerking agrarische producten } \\
2018\end{array}$ & 2 & 0 & $€ 930.000$ & nog in behandeling \\
\hline
\end{tabular}

Bron: RVO.

In de openstelling regeling Fysieke investeringen industriële verwerking agrarische producten heeft Avebe in 2018 een tweetal aanvragen ingediend die nog worden behandeld, en in deze niet worden meegenomen.

\subsection{Doeltreffendheid}

\section{Algemeen}

Een enquête ${ }^{14}$ over de regeling Fysieke investeringen is uitgezet onder alle ondernemers waarvan de aanvraag is goedgekeurd (hoewel nog niet in alle gevallen is uitbetaald). Door 122 respondenten $(37 \%)$ is de enquête volledig ingevuld. De meeste respondenten zijn gevestigd in regio Noord, akkerbouw is qua sectoren het sterkst vertegenwoordigd (figuur 3.3). Gezien de omvang van het onderzoek zijn geen ondernemers met afgewezen aanvragen, of ondernemers die geen aanvraag hebben ingediend in de enquête meegenomen.

\footnotetext{
${ }^{14}$ Zie bijlage 2 voor de uitgevoerde enquête.
} 


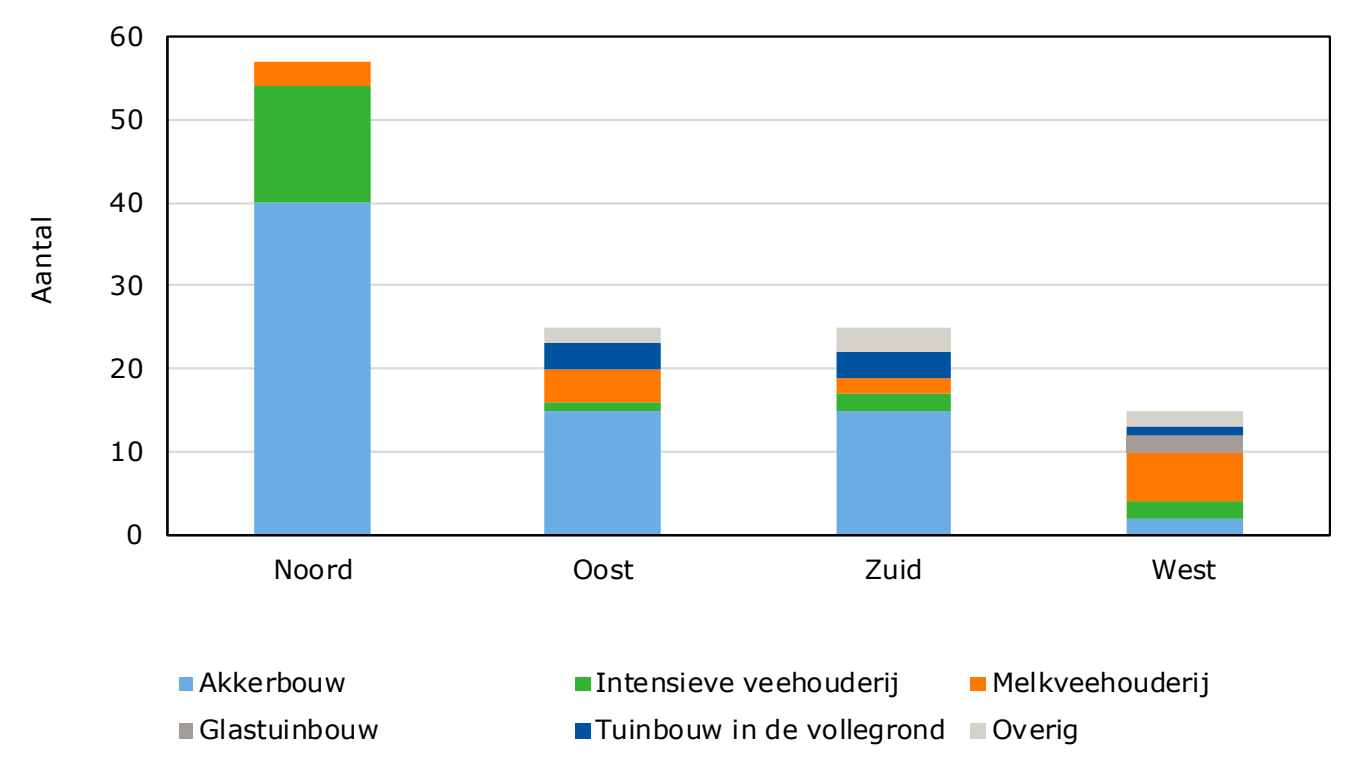

Figuur 3.3 Enquête: Aantal respondenten naar regio en sector

In het vervolg van de analyse van deze enquête, zijn de sectoren 'intensieve veehouderij' en 'melkveehouderij' samengevoegd tot 'veehouderij', zodat deze groep uit 35 respondenten bestaat (zie tabel 3.2). Samen met de akkerbouw wordt de veehouderij apart als groep weergegeven in de volgende figuren en analyses. De andere landbouwsectoren in figuur 3.3, worden in het vervolg van deze analyse niet als een aparte groep in beeld gebracht vanwege het beperkte aantal respondenten. In regio West is de respons van 15 aan de lage kant. De regio wordt wel getoond in de figuren, maar niet specifiek in de analyse betrokken.

De twee wijzen van openstelling van de regeling komen ook naar voren in de aanmelding voor de regeling. Iets meer dan de helft van de respondenten (55\%) heeft de Regeling Fysieke investeringen aangevraagd op basis van een investeringslijst, iets minder dan de helft via open inschrijving.

Tabel 3.2 Respons enquête naar subgroep

\begin{tabular}{lr} 
Categorie & Aantal \\
Sector & 122 \\
w.v. Veehouderij & 34 \\
$\quad$ Akkerbouw & 72 \\
\hline Landsdeel a) & 122 \\
West & 15 \\
Zuid & 15 \\
Oost & 25 \\
Noord & 25 \\
\hline
\end{tabular}

a) Aangehouden Regio-indeling uitwerking enquête komt niet geheel overeen met de bestuurlijke indeling:

- Noord: Friesland, Drenthe, Groningen

- Oost: ${ }^{15}$ Flevoland, Gelderland, Overijssel

- West: Noord-Holland, Zuid-Holland, Utrecht

- Zuid: Zeeland, Noord-Brabant, Limburg.

De bedrijven die hebben deelgenomen aan de enquête hebben het vaakst geïnvesteerd in precisielandbouw (41 keer). Ongeveer de helft van dit aantal investeerde in productiesysteem dat moet leiden tot een (in meerdere mate) gesloten kringloop. Bekijken we de twee belangrijkste

\footnotetext{
${ }^{15}$ De provincie Flevoland is bij de uitwerking van de enquête onder landsdeel Oost meegenomen. Bij de bestuurlijke indeling wordt de provincie Flevoland meegenomen onder landsdeel West.
} 
landbouwsectoren die gebruik maken van de regeling, dan is de top 3 aan investeringscategorieën in de akkerbouw precisielandbouw, emissiearme spuittechnieken en bodembeheer; in de melkveehouderij zijn dat de duurzame stallen, meer gesloten kringlopen en precisielandbouw. ${ }^{16}$ Zie bijlage 2, figuren B2.11 en B2.12.

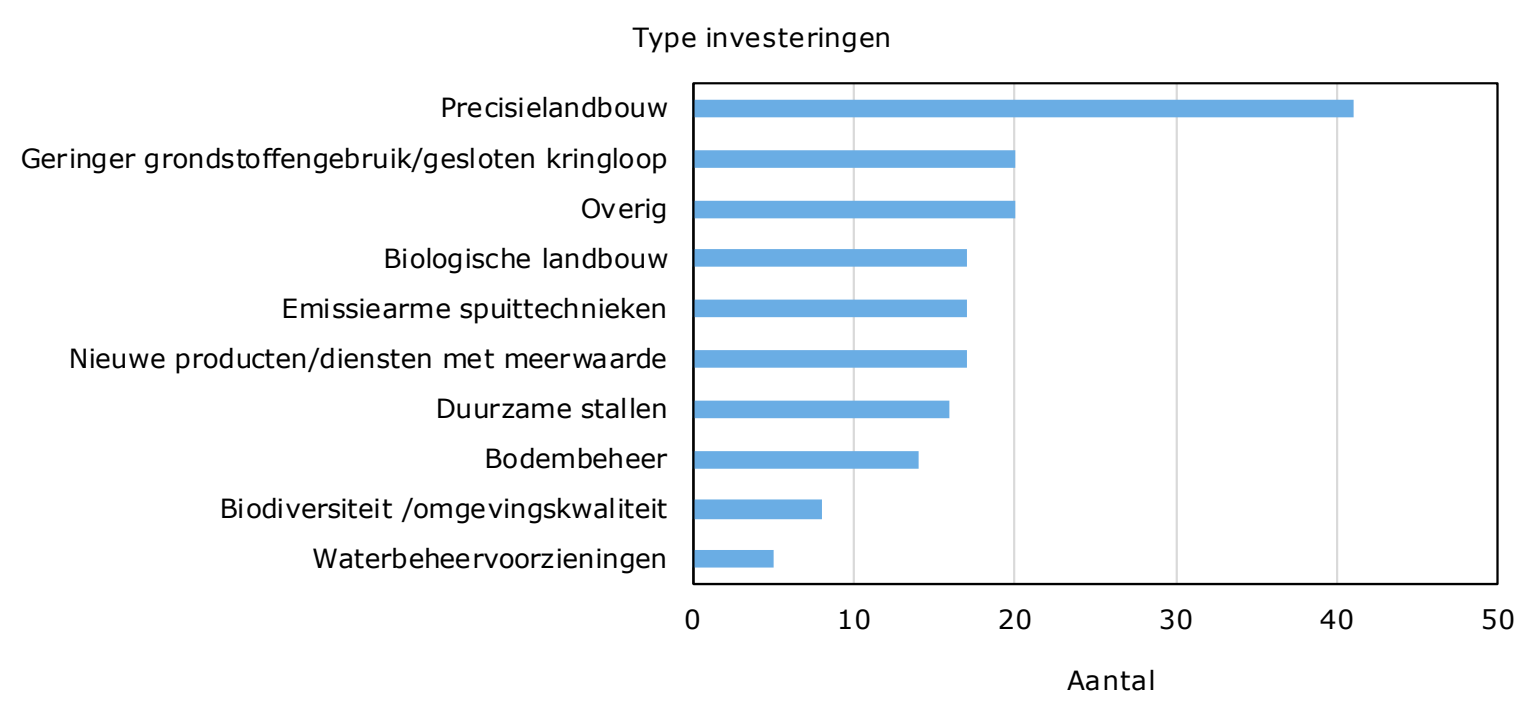

Figuur 3.4 Enquête: Goedgekeurde aanvragen maatregel Productieve fysieke investeringen naar belangrijkste investeringscategorieën, 2016 tot en met 2018 a)

a) Totaal aantal investeringen (175) is hoger dan aantal respondenten (122); ondernemers kunnen voor meerdere investeringen subsidie krijgen en een investering kan betrekking hebben op meer dan 1 type.

De investeringen waarvoor subsidie is ontvangen sloten in $80 \%$ van de gevallen 'zeer goed' of 'goed' aan bij de investeringsbehoefte van de ondernemer (figuur B2.1). Een klein deel van de respondenten gaf aan dat de aansluiting slecht is.

In bijna $90 \%$ van de gevallen was de investering die uitgevoerd is met behulp van de regeling 'zeer belangrijk' of 'belangrijk' voor modernisering en innovatie van het bedrijf (figuur 3.5). Ook de geïnterviewden, financieel adviseurs en POP-coördinatoren, onderschrijven dat de regeling een sterke stimulering is voor innovaties en modernisering. Vooral voorlopers in de sector worden ondersteund.

\footnotetext{
${ }^{16}$ RVO beschikte niet over een indeling van de bedrijven naar een investeringscategorie, mede omdat een belangrijk deel van de goedgekeurde aanvragen plaatsgevonden heeft via open inschrijving. Wageningen Economic Research heeft in de vragenlijst van de enquête een zo goed mogelijk dekkende lijst met investeringscategorieën opgesteld (bijlage 2).
} 
Hoe belangrijk is de investering, waarvoor u subsidie is toegekend vanuit de regeling Fysieke investeringen voor innovatie en modernisering, voor uw bedrijf?

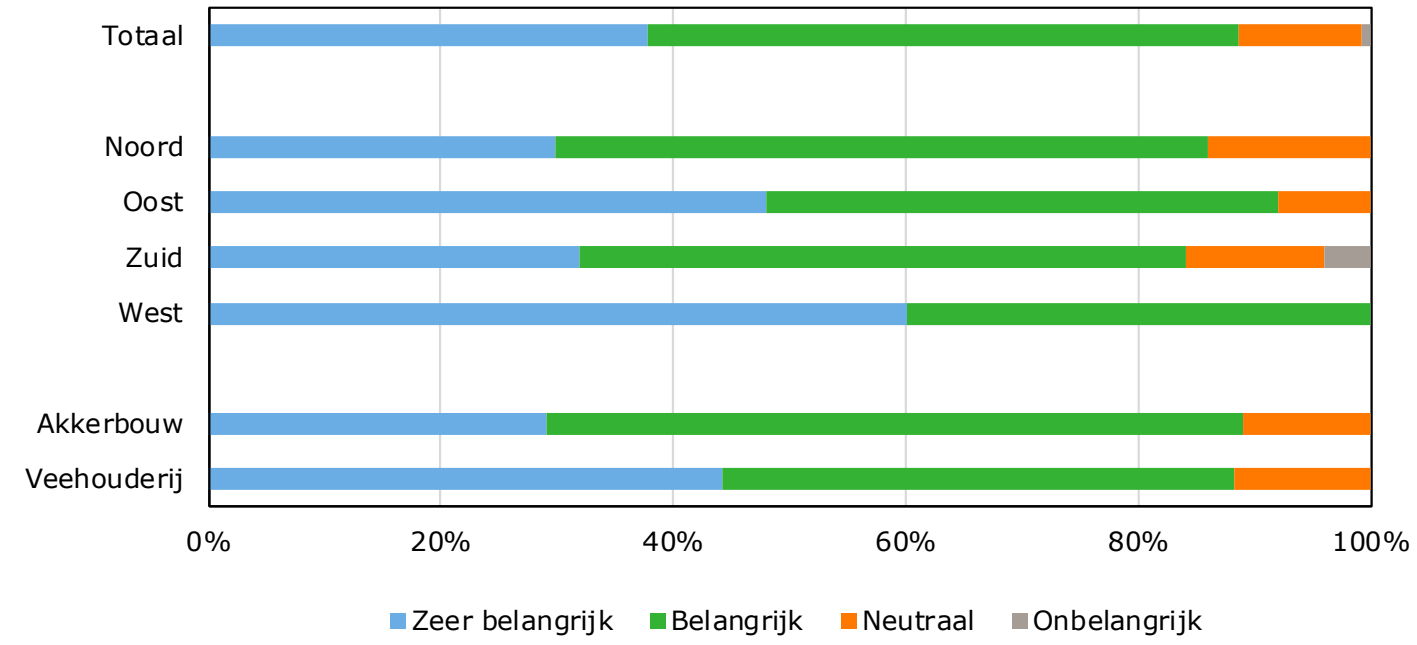

Figuur 3.5 Enquête: Belang van regeling Fysieke investering voor innovatie en modernisering

Met betrekking tot de uitvoering van de investering is in de enquête een aantal stellingen voorgelegd (zie bijlage 2 voor de figuren).

- Ruim $80 \%$ van de respondenten gaf aan dat de regeling heeft geholpen met het doorzetten van onderdelen van het investeringsproject (figuur B2.2).

- Ruim de helft van de respondenten was het 'zeer eens' of 'eens' met de stelling dat met behulp van de regeling het investeringsproject eerder gestart kan worden, dus duidelijk naar voren is gehaald (figuur B2.3). In de akkerbouw lag dit percentage hoger dan in de veehouderij. Dit heeft waarschijnlijk mede te maken met het type investering en het gemoeide bedrag met de investering. Een investering in een duurzame stal is moeilijker naar voren te halen in de tijd (is de aanwezige stal al zo goed als afgeschreven) en duurder dan een investering in apparatuur zoals voor precisielandbouw.

- De kwaliteit van de investering kon volgens een ruime meerderheid (80\%) verbeterd worden met behulp van de regeling (figuur B2.4). In de regio Zuid was men het in mindere mate eens met deze stelling.

- De investering werd in ongeveer de helft van de gevallen grootschaliger opgepakt vanwege de bijkomende subsidie (figuur B2.5). In de veehouderij was men het in bijna $40 \%$ van de gevallen 'oneens' of 'zeer oneens' met deze stelling.

- Bij ongeveer de helft van respondenten kon het investeringsproject eerder worden uitgevoerd in de tijd met behulp van de subsidie (figuur B2.6). Bij de veehouderij was dit in mindere mate het geval dan in de akkerbouw. In regio Noord met voornamelijk deelnemers uit de akkerbouw was het beeld dan ook positiever dan in de andere regio's.

- De subsidie in het kader van de maatregel Productieve fysieke investeringen had volgens een grote meerderheid van de respondenten een meerwaarde (figuur 3.6). Van de respondenten was $80 \%$ het 'oneens' of 'zeer oneens' met de stelling dat de subsidie geen meerwaarde heeft. In regio Zuid werd de meerwaarde van de subsidie enigszins betwijfeld door $20 \%$ van de respondenten. Een reden hiervoor is waarschijnlijk de zeer lange doorlooptijd beoordeling aanvragen van de eerste openstelling (begin 2017) in Noord-Brabant, die pas in maart 2018 is afgerond. Inhoudelijk is er juist tevredenheid over de maatregel. De laatste jaren is in Noord-Brabant juist een grote inhaalslag gemaakt.

Uit de gehouden interviews kwam naar voren dat een substantieel deel van deze bovenwettelijke investeringen in deze vorm zonder deze POP3-subsidie niet zou zijn uitgevoerd. Daarbij gaat het vooral om investeringsplannen waarin de ondernemer extra financieel risico neemt. Hierbij is het belang van de subsidiecomponent groot omdat de externe financiering anders niet of nauwelijks van de grond komt. 


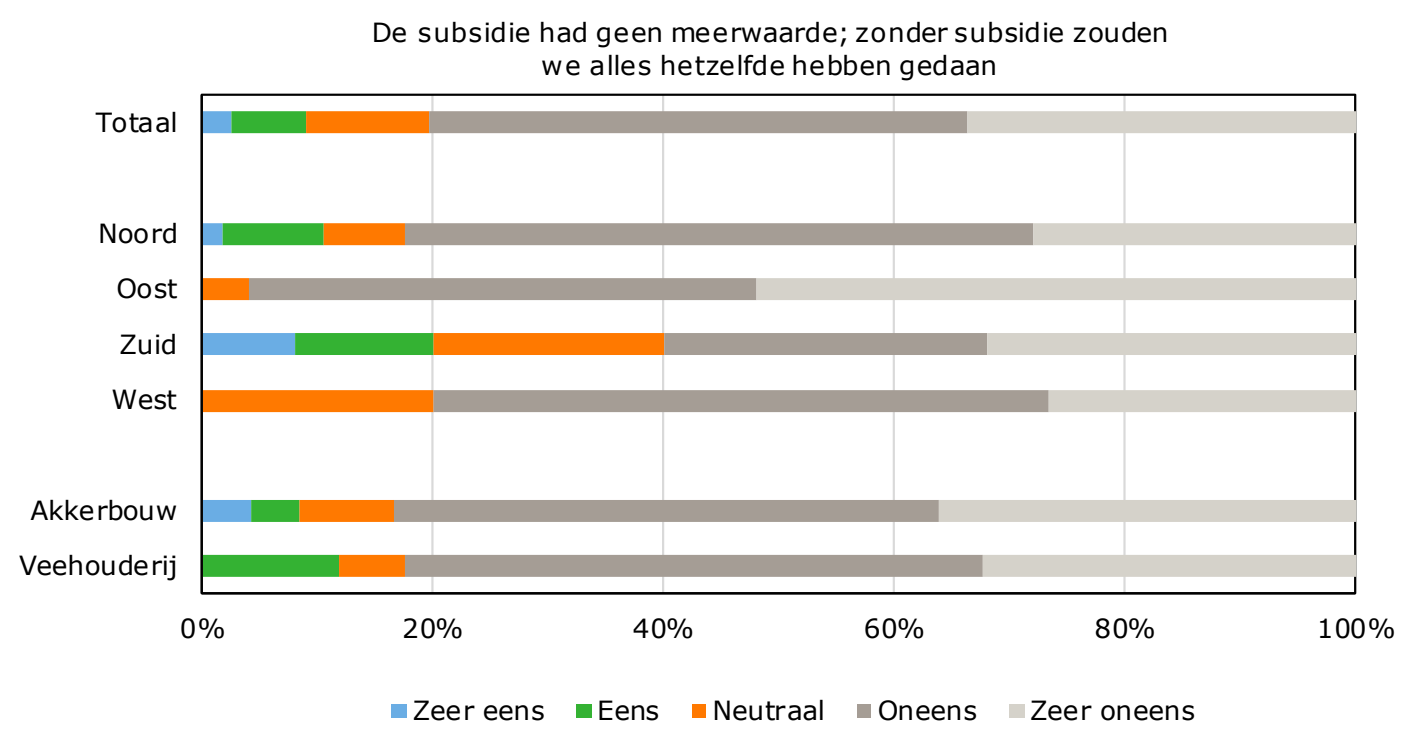

Figuur 3.6 Enquête: Subsidie had geen meerwaarde voor het bedrijf

Het verwachte effect van de investering op de verhoging van de omzet is in de meeste gevallen beperkt. Volgens de geïnterviewde experts komt dit mede doordat de investering kortgeleden heeft plaatsgevonden (2016 tot en met 2018) en het omzeteffect lastig in te schatten is, en het per definitie om bovenwettelijke maatregelen gaat. Toch geeft een op de vijf aan dat het effect 'zeer groot' tot 'groot' is (figuur B2.7). In enkele gevallen werd er een negatieve invloed ervaren. Geïnterviewden gaven aan dat dit te maken heeft met aard van de investeringen: innovaties bieden geen garantie voor betere economische prestaties. Ook moet $60 \%$ van de investering zelf gefinancierd worden en dat kan in sommige gevallen leiden tot een grote druk op de financiële draagkracht. Ofwel: hoe groot is nog de marge om de extra rente- en aflossing structureel te dragen?

Ongeveer $30 \%$ van de respondenten geeft aan dat het effect van de subsidie op het verlagen van de productiekosten 'zeer groot' tot 'groot' is (figuur B2.8). In de akkerbouw is men het hier in sterkere mate mee eens dan in de veehouderij. Dat heeft mogelijk te maken met het type investeringen. In regio Zuid is een relatief grote groep respondenten die het effect als 'enigszins negatief' of 'negatief' beoordelen.

Bijna $80 \%$ van de respondenten geeft aan dat het effect van de regeling op de modernisering en innovatie 'zeer groot' tot 'groot' is (figuur B2.9). Dit heeft volgens de geïnterviewden, naast de insteek van de regeling, mede te maken met substantieel hoge maximum investeringsbedragen. Er zijn echter wel aanzienlijke verschillen in maximumbedragen tussen de provincies aanwezig. Zo kiest de provincie Noord-Holland bewust voor een hoog maximumbedrag met de mogelijkheid in te zetten op meerdere doelen. Ook ten aanzien van duurzaamheid is $80 \%$ van de respondenten van mening dat het effect van de regeling 'zeer groot' tot 'groot' is (figuur 3.7). Bij de veehouderij wordt het effect positiever beoordeeld dan in de akkerbouw.

In de akkerbouw geeft bijna $80 \%$ van de respondenten aan dat het belang van voortzetting van de regeling Fysieke investeringen 'zeer groot' tot 'groot' is (figuur 3.8). Bij de veehouderij ligt dit zelfs rond de $90 \%$. In regio Zuid wordt het belang minder hoog ingeschat dan in de andere regio's. Ook hier speelt waarschijnlijk de zeer lange doorlooptijd goedkeuringen eerste openstelling een rol. 
Effecten op de prestaties en continuiteit: verbetering van de duurzaamheid van het bedrijf

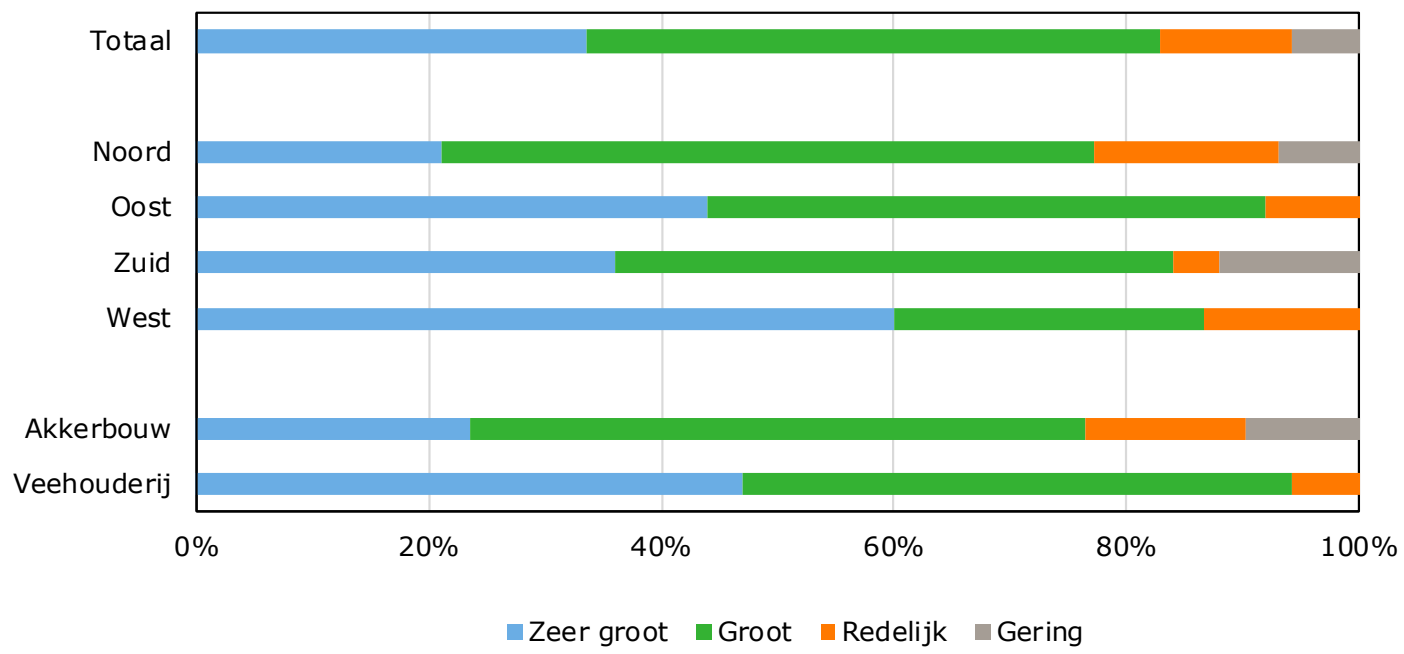

Figuur 3.7 Enquête: Effect van regeling op de duurzaamheid van het bedrijf

Ook de geïnterviewden onderschrijven het belang van de regeling. De regeling voorziet duidelijk in een behoefte voor 'voorlopers', innoverende bedrijven. Wat nog stimulerend zou kunnen werken is het opnemen van een demonstratie, open dag in de regeling. Hiermee kun je het effect van de subsidie nog breder onder de aandacht brengen.

Welk belang hecht $u$ aan voortzetting van de regeling Fysieke investeringen voor innovatie en modernisering binnen POP3?

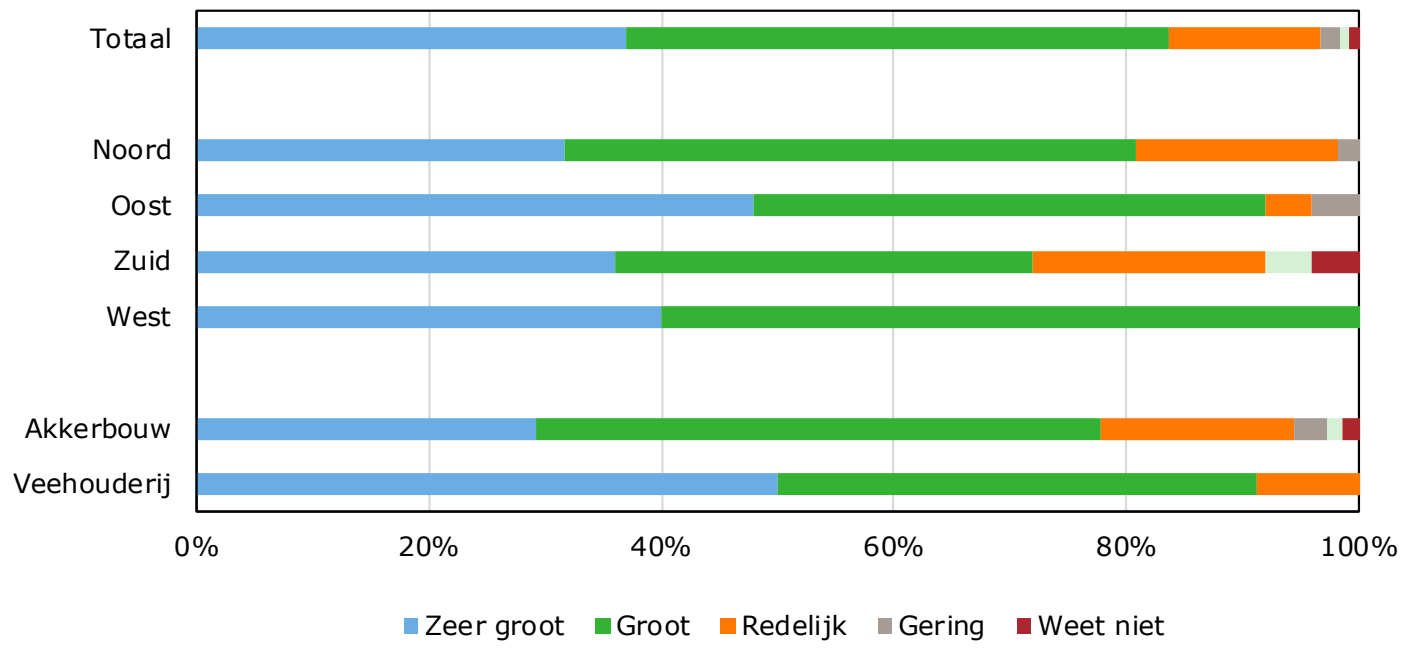

Figuur 3.8 Enquête: Belang van voortzetting regeling voor innovatie en modernisering

\section{Veenkoloniën}

De fysieke investeringen in innovatie en modernisering (apparatuur) zullen leiden tot een modernisering en verduurzaming van het productieproces. Door de late openstelling zijn er nog geen effecten meetbaar. De aanvragen binnen de maatregel Productieve fysieke investeringen industriële verwerking agrarische producten zijn in 2018 nog niet goedgekeurd. De verwachting is dat deze subsidies leiden tot een verbetering van de verwerking van producten, en richting de boer in de prijs deels tot uitdrukking kan komen. 
Tabel 3.3 Bijdrage maatregel Productieve fysieke investeringen aan algemene evaluatievragen EU (bijvangst, zie ook bijlage 7)

\begin{tabular}{|c|c|}
\hline Algemene vragen EU & Maatregel Productieve fysieke investeringen \\
\hline $\begin{array}{l}\text { Bevordering concurrentievermogen } \\
\text { agrarische sector }\end{array}$ & $\begin{array}{l}\text { De bovenwettelijke investeringen zullen naar verwachting tijdens POP3 (een nog } \\
\text { beperkte) invloed hebben op de productiekosten. Er worden niet direct duidelijke } \\
\text { opbrengstverhogingen verwacht. Extra investeringen kunnen ook weer leiden tot } \\
\text { extra financieringskosten. Per saldo zal de komende jaren het effect op inkomens } \\
\text { en concurrentiekracht beperkt zijn. Wel biedt het een impuls aan verduurzaming } \\
\text { productieproces en daarmee ook perspectief om te blijven produceren (licence to } \\
\text { produce). }\end{array}$ \\
\hline $\begin{array}{l}\text { Bevorderen van innovatie in } \\
\text { agrarische sector }\end{array}$ & $\begin{array}{l}\text { De regeling betreft bovenwettelijke investeringen die een sterke impuls geven aan } \\
\text { het innovatieproces/modernisering op deze bedrijven en daarmee deels in de } \\
\text { sector }\end{array}$ \\
\hline $\begin{array}{l}\text { Waarborgen duurzaam beheer } \\
\text { natuurlijke hulpbronnen en } \\
\text { klimaatactie }\end{array}$ & $\begin{array}{l}\text { De bovenwettelijke investeringen richten zich onder andere op precisielandbouw, } \\
\text { meer gesloten kringlopen, emissiearme spuittechnieken, bodembeheer. Veel van } \\
\text { deze investeringen dragen bij aan een duurzamer beheer van de hulpbronnen en } \\
\text { klimaat (denk aan slimmer grondgebruik, kringlopen, biodiversiteit). }\end{array}$ \\
\hline
\end{tabular}

Kalverhouderij 17

\subsection{Doelmatigheid}

Het uitvoeringsproces door de provincie en RVO wordt door een meerderheid van de respondenten als 'goed' beoordeeld (figuur B2.10). Ongeveer 10\% vond het uitvoeringsproces 'slecht' tot 'zeer slecht'. In regio Oost en Zuid was de ontevredenheid groter dan in regio Noord. Ook waren akkerbouwers wat minder positief dan de veehouders.

Aan het eind van de enquête is een open vraag gesteld om respondenten de gelegenheid te geven aanvullende informatie te verstrekken die van belang kan zijn voor de evaluatie. Hiervan is door 35 personen (29\%) gebruikgemaakt. De opmerkingen zijn samengevoegd tot enkele categorieën (figuur 3.9). Er is 12 keer een opmerking gemaakt over de ingewikkeldheid van de procedure (zie voorbeeld tekstbox 3.1). De ingewikkelde procedure vraagt veel tijd en geld voor adviseurs was de algemene teneur. Door 6 respondenten werd opgemerkt dat de uitbetaling te lang op zich laat wachten en dat de ondernemers de investering moet voorschieten. Ook waren er 7 ondernemers die vonden dat de subsidiabele investeringen beter zouden kunnen aansluiten bij de wensen. Eén respondent vat in één zin samen wat in grote lijnen uit de evaluatie van deze regeling naar voren komt (tekstbox 3.2): de regeling helpt om investeringen te doen die anders niet gedaan zouden zijn, maar de procedure wordt als ingewikkeld en langdurig ervaren.

\footnotetext{
${ }^{17}$ Hoewel er tot en met eind 2018 geen goedkeuringen zijn geweest zal de regeling kalverhouders de mogelijkheid bieden te investeren in welzijnsvriendelijke vloeren zonder een hoge extra prijs te betalen. Belangrijk daarbij is dat dergelijke investeringen aansluiten bij het investeringsritme (en afschrijvingen) van de bedrijven. De subsidiebijdrage om te investeren in deze relatief dure maatregelen voor reductie van ammoniakemissie geeft een minder hoge extra financiële last en leidt tot een versnelling van welzijnsvriendelijke vloeren. Ondanks de hoge animo, is onderzoek naar de effecten van welzijnsvloeren nog niet geheel overtuigend geweest in het voordeel van kalf en kalverhouder. De investeringen in ammoniakreductie zullen vanaf 2019 een bijdrage leveren aan verduurzaming van het productieproces en klimaat.
} 


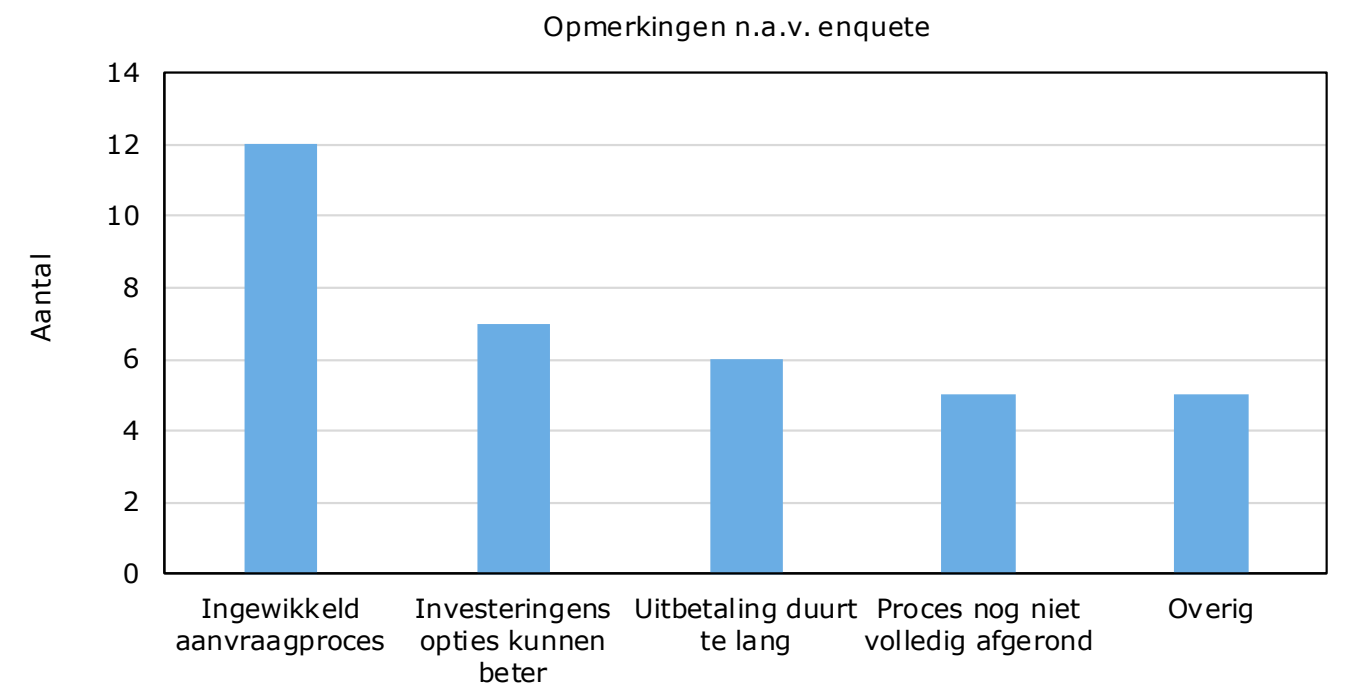

Figuur 3.9 Enquête: Aanvullende opmerkingen geënquêteerden naar categorie

\section{Tekstbox 3.1}

'Aanvragen in deze regeling zijn omslachtig en je moet kosten maken door inhuren van mensen die hier veel verstand van hebben. Het is zelf niet te realiseren en werkt ontmoedigend. Kortom: de regeling zou simpeler moeten zijn om aanvragen in te dienen.'

\section{Tekstbox 3.2}

'POP3 is een mooie regeling. Apparatuur voor precisielandbouw is relatief duur, zonder subsidie hadden wij hier niet in geïnvesteerd. Aanvraag is moeilijk en afwikkeling duurde lang, maar al met al mooi resultaat.'

Vanuit betrokken adviseurs (geïnterviewden) werden de volgende opmerkingen gemaakt bij het uitvoeringsproces:

- Beoordelingstermijn van 22 weken is lang en wordt regelmatig ook niet gehaald, 22 weken is al lang voor een bedrijf dat wil innoveren. Het proces verloopt nogal eens stroperig vanwege betrokkenheid van zowel de provincies als RVO. Eerst beoordeelt een adviescommissie van deskundigen de aanvraag en vervolgens nog financiële beoordeling door uitvoerorgaan (RVO). Provincie is geen betaalorgaan in deze, de aanvraag moet zodoende over veel schijven.

- De voorwaarden zijn voor de ondernemer ook niet altijd duidelijk. Per openstelling kunnen deze sterk verschillen. Doordat de openstelling nu te veel ad hoc is, is het voor ondernemers lastig sturen en plannen. Elke provincie maakt hierin zijn eigen keuzes. Behoefte aan meer clustering, landelijke sturing.

\section{Veenkoloniën}

De invulling en opstart van de regeling Fysieke investeringen innovatie en modernisering heeft een tijd geduurd waardoor openstelling pas voor het eerst in 2017 plaatsvond. In goed overleg met de praktijk hebben de provincies Groningen en Drenthe (in goede samenwerking) een investeringslijst opgesteld. De subsidies zijn vooral naar apparatuur met de hoogste scores (gebaseerd op de beoogde doelen) gegaan. Nadeel hiervan is dat een belangrijk deel van het machinepark niet in aanmerking is gekomen voor subsidie, wat ook teleurstelling met zich meebrengt.

\section{Kalverhouderij (als bijvangst)}

De sector is tevreden over het intensieve contact vooraf met het Rijk om de regeling zo goed mogelijk in te vullen en daarmee aan te laten sluiten bij de behoeften van de sector. Ook is bij de invulling van de regeling gebruik gemaakt van onderzoeksresultaten (rapport Alternatieven vloeren voor 
vleeskalveren van Wageningen Livestock Research, 2017). Er is vooraf veel publiciteit geweest rond deze regelingen vanuit de periferie van de sector.

Een lijst vooraf (RAV) met onderbouwde ammoniakreductiepercentages heeft duidelijkheid gegeven. Toch zijn meerdere ammoniakreductiesystemen nog niet omvangrijk bekend in de kalverhouderij.

\subsection{Conclusies en aanbevelingen}

\section{Bereik}

- In de periode 2016 tot en met 2018 is voor ruim $€ 38 \mathrm{mln}$. subsidie toegekend in het kader van de maatregel Productieve fysieke investeringen, anderzijds zijn er aanvragen ter waarde van bijna $€ 63 \mathrm{mln}$. afgewezen, voornamelijk als gevolg van overtekening van beschikbare budget.

- Limburg heeft het grootste bedrag aan subsidies verleend, namelijk ruim $€ 8 \mathrm{mln}$.

- Gemiddeld is het verleende bedrag per aanvraag in de periode 2016 tot en met 2018 bijna 100.000 euro. In Noord-Holland was dit het hoogst met gemiddeld $€ 350.000$. Dit heeft te maken met een hoog maximum- en minimumbedrag per aanvraag en aanvragen met meerdere doelen;

- Regeling fysieke investeringen innovatie en modernisering Veenkoloniën: het bereikte aantal ondernemers tot en met 2018 is met 48 beperkt, mede door late openstelling.

\section{Doeltreffendheid}

- Het grootste deel van de respondenten (80\%) vindt dat gesubsidieerde investering goed aansluit bij de persoonlijke investeringsbehoefte.

- $80 \%$ van de respondenten vindt dat de regeling een duidelijke meerwaarde heeft. In regio Zuid is men hier iets minder positief over. Geïnterviewden gaven ook aan dat veel investeringen in deze vorm zonder subsidie niet zouden zijn uitgevoerd. Daarbij gaat het vooral om investeringsplannen waarin de ondernemer extra financieel risico neemt. Hierbij is het belang van de subsidiecomponent groot omdat de externe financiering anders niet of nauwelijks van de grond komt.

- In de akkerbouw heeft de regeling meer bijgedragen aan het versnellen of eerder uitvoeren van een investering dan in de veehouderij.

- De investeringen uitgevoerd in het kader van de regeling hebben een groot effect op de duurzaamheid, en modernisering van het bedrijf.

- Het effect van de regeling op het verbeteren van de economische prestaties is in de meeste gevallen beperkt. Het effect van de investering op verlaging van de productiekosten wordt door de respondenten groter ingeschat dan het effect op de verhoging van de omzet. Hierbij moet worden opgemerkt dat er ook investeringen met een uitvoertermijn van 2-3 jaar zijn, waarvan het effect nu nog moeilijk valt in te schatten.

- Het grootste deel van de respondenten hecht veel belang aan het doorzetten van de regeling.

- De investeringen in apparatuur binnen de regeling Fysieke investeringen innovatie en modernisering Veenkoloniën zullen leiden tot modernisering en verduurzaming van het productieproces. Door openstellingen in 2017 en 2018 zijn er nog geen effecten meetbaar.

\section{Doelmatigheid}

- De meeste opmerkingen van de respondenten naar aanleiding van de enquête gaan over de ingewikkeldheid van de procedure.

- Vanuit meerdere provincies wordt de regeling gezien als maatwerk voor uitvoering van beleidsdoelen. De ervaringen met open inschrijvingen lopen uiteen, sommige provincies gebruiken of zijn overgegaan op investeringslijsten.

- Ook kunnen provincies meer leren van elkaars ervaringen rond openstellingen en procedures.

- De investeringslijst voor de regeling Fysieke investeringen innovatie en modernisering Veenkoloniën is in goede harmonie met de sector samengesteld. Door de vele aanvragen komen aanvragen voor apparatuur met iets minder hoge scores niet in aanmerking, met bijkomende kosten aanvraag

\section{Aanbevelingen}

- Continueer de huidige regeling fysieke investeringen maar streef naar meer harmonisatie in de uitvoering, naar meer samenwerking tussen de provincies in het gelijk trekken van de investeringsmogelijkheden en de periode van openstelling. 
- Help innovators vooruit met een jaarlijkse openstelling. Dat geeft agrariërs duidelijkheid.

- Het aantal afwijzingen door overtekening van het budget onder de maatregel Productieve fysieke investeringen is hoog, wat vanuit de agrarische sector als demotiverend wordt ervaren. Probeer een systematiek aan te houden waarbij het \% afwijzingen (en bijkomend aangevraagd budget) wordt beperkt. Probeer in de opeenvolgende openstellingen te variëren in investeringen, zodat meerdere sectoren gedurende de POP-periode aan bod komen. In sommige provincies gebeurt dit al. 


\section{$4 \quad$ Jonge landbouwers-regeling (maatregel 4.1.2)}

Belangrijkste bevindingen

De mate van bereik van de vooraf gestelde streefwaarden van de output- en resultaatindicatoren

- In de periode 2016 tot en met 2018 zijn gedurende 3 openstellingen 1.248 aanvragen van de Jonge landbouwers-regeling (JoLa-regeling) goedgekeurd. Een $45 \%$ (581) is in 2018 goedgekeurd.

- Het toegekende bedrag was eind 2018 ruim $€ 21 \mathrm{mln}$. Het totaal beschikbare budget voor de gehele POP3 periode bedraagt $€ 35,76 \mathrm{mln}$.

- Het gemiddeld verleende bedrag per aanvraag bedroeg $€ 17.000$.

- Bijna de helft van de aanvragers is tussen de 35 en 40 jaar oud.

- Er is geïnvesteerd in ruim 20 investeringscategorieën. Maar liefst $45 \%$ van het budget is geïnvesteerd in zonnepanelen.

- Het bereik is groot in vergelijking met de streefwaarden. Toch bereikt de JoLa-regeling lang niet alle jonge ondernemers.

\section{Doeltreffendheid}

- Het effect van de JoLa-regeling op de verhoging van de omzet of het verlagen van de productiekosten wordt niet heel groot geacht, gezien ook het karakter van de investeringen (bovenwettelijk, minder passend bij de normale bedrijfsvoering). Wel was er een duidelijk effect op de duurzaamheid en moderniteit van het bedrijf;

- Resultaat enquête begunstigers: $62 \%$ vindt de JoLa-regeling goed aansluiten bij de investeringsbehoefte. In de akkerbouw sloot het beter aan dan bij de veehouderij. Daarnaast vindt $86 \%$ de toegekende subsidie 'zeer belangrijk' of 'belangrijk' voor duurzame bedrijfsinvesteringen. Een klein deel van de ondernemers had zonder de JoLa-regeling dezelfde investeringen uitgevoerd. Een grote meerderheid hecht groot belang aan continuering JoLa-regeling;

- Er is meer aandacht nodig voor passende investeringen voor met name kleine sectoren, voor type investeringen die beter aansluiten bij het primaire proces, dit ook gezien de fase ondernemerschap met financiële lasten van een overname). Door provinciaal beleid komen bepaalde groepen jongeren beperkt niet in aanmerking;

- Het effect van de JoLa-regeling op het besluit tot overname bedrijf is voor de meerderheid van de ondervraagde jonge boeren 'gering' of er was 'geen' effect. De subsidie is gering in vergelijking tot de financiering van de bedrijfsovername.

\section{Aanbevelingen}

- Houd de 'basis' investeringslijst constant en voeg investeringscategorieën toe met meer oog voor de 'kleine', specifieke deelsectoren.

- Onderzoek mogelijkheden om via verschuivingen extra budget toe te delen aan deze regeling, gezien de grote interesse en vergroting bereik onder jonge agrariërs.

\subsection{Beleidstheorie}

De overheid stimuleert en ondersteunt jonge landbouwers onder de 41 jaar met de POP3-subsidie Jonge landbouwers. Met de regeling Jonge landbouwers (JoLa-regeling) steunt de overheid deze groep agrarisch ondernemers met de aanschaf van duurzame investeringen, die vallen onder bovenwettelijke verplichtingen. Daarmee kunnen zij beter inspelen op marktontwikkelingen en wensen van de samenleving.

In de eerste openstelling waren er 14 investeringscategorieën onderscheiden waarvoor subsidie kon worden verstrekt (Bureau Bartels, 2016). Vanaf de derde openstelling is dit verruimd naar 27 investeringscategorieën waarvoor de jonge boer subsidie kon krijgen. Het subsidiepercentage is $30 \%$ van de subsidiabele kosten. Er is geen maximum aan subsidiabele kosten, wel een 
maximumsubsidiebedrag van $€ 20.000$. Het minimumsubsidiebedrag is $€ 10.000$. Een jonge ondernemer kon voor maximaal 3 investeringen subsidie aanvragen. Er is geen minimum meer aan subsidiabele kosten per investering. Inmiddels zijn er 4 openstellingen van de JoLa-regeling geweest (zie tabel 4.1).

\section{Tabel 4.1 Openstellingen van de JoLa-regeling}

Openstelling 1: 1 maart tot en met 14 april 2016

Openstelling 2: 1 december 2016 tot en met 16 januari 2017

Openstelling 3: 4 december 2017 tot en met 15 januari 2018

Openstelling 4: 3 december 2018 tot en met 8 februari 2019.

Deze regeling wordt door de provincies opengesteld en uitgevoerd. Elke provincie publiceert inhoudelijk dezelfde regeling en hetzelfde openstellingsbesluit. Wel kunnen per provincie het subsidieplafond en de subsidiabele investeringen uiteenlopen. Provincies hebben bij elke openstelling de mogelijkheid om een of meerdere investeringscategorieën uit te sluiten waarbij kan worden aangesloten op provinciale beleidsdoelen. De werkgroep JoLa, bestaande uit experts en een vertegenwoordiging van beleidsmedewerkers van een aantal provincies, bekijkt periodiek naar mogelijke aanpassingen in de lijst. Ook luistert de werkgroep naar de wensen en behoeften die de jongerenorganisatie NAJK inbrengt.

De eerste openstelling van de JoLa-regeling is op verzoek van het ministerie van Economische Zaken en Regiebureau POP geëvalueerd door Bureau Bartels (Bureau Bartels, 2016). Hierin is aandacht geschonken aan de 'inhoud' en 'werkwijze' van deze openstelling. Hierbij is een deskresearch verricht en zijn vertegenwoordigers van het Regiebureau POP, RVO.nl, provincies, het (N)AJK, adviseurs en jonge landbouwers - die een aanvraag voor de JoLa-regeling ingediend hebben - geraadpleegd. Dit heeft geresulteerd in de volgende aanbevelingen:

1. Houd de basis of kern van de investeringslijst zoveel mogelijk constant maar voeg een aantal investeringscategorieën toe en tracht daarbij (meer) aansluiting te realiseren bij de behoeften van jonge landbouwers.

2. Geef eerder - dus ruim voor de openstellingen - meer duidelijkheid over de inhoud en momenten van opstellingen.

3. Overweeg de minimale grens van $€ 20.000$ per investering af te schaffen.

4. Overweeg de staffelkorting voor oudere deelnemers in de maatschap af te schaffen.

5. Overweeg een 'top-up' in te stellen voor jonge landbouwers die het bedrijf volledig overgenomen hebben.

6. Zorg voor verbeteringen bij het digitaal indienen van aanvragen.

7. Tracht versnelling aan te brengen in de besluitvorming over de aanvragen.

8. Leg bij volgende openstellingen de vraagbaakfunctie uitsluitend bij RVO.nl neer (Bureau Bartels, 2016).

Naast de officiële evaluatie uitgevoerd door Bureau Bartels heeft het NAJK ook een eigen enquête naar de openstelling van de $1^{\mathrm{e}}$ JoLa-regeling uitgevoerd onder haar leden (NAJK, september 2016). Hieruit komt naar voren dat de JoLa-regeling zeer goed bekend is onder de jonge ondernemers. De investeringen op de investeringslijst passen evenwel lang niet altijd bij hun behoeften in deze periode van de bedrijfscyclus. Er zijn dan ook veel praktische doeltreffende investeringen genoemd om op te nemen in de investeringslijst.

Op basis van de uitkomsten van de evaluatie door Bureau Bartels, en mede ook op advies van het NAJK, zijn in de $3^{\mathrm{e}}$ openstelling - december 2017 - een aantal wijzigingen doorgevoerd. ${ }^{18}$ Belangrijkste verandering is de uitbreiding en aanpassing van de investeringslijst. Daarnaast is er geen minimum meer aan subsidiabele kosten per investering. Het minimale subsidiebedrag van $€ 10.000$ blijft wel gelijk.

\footnotetext{
${ }^{18}$ De 2e openstelling in december 2016 kwam te vroeg om een aantal wijzigingen uit de evaluaties door te voeren.
} 


\subsection{Bereik}

In de periode 2016 tot en met 2018 (met 3 openstellingen) zijn 1.248 aanvragen van de JoLa-regeling toegekend. ${ }^{19}$ Hiervan hadden er 581 (iets minder dan helft) betrekking op 2018. Mogelijk is dit het effect van aanpassingen in de regelingen bij de derde openstelling. Hierbij speelt ook een rol dat 2017 voor de land- en tuinbouw een bijzonder goed inkomensjaar was (www.agrimatie.nl). Hierdoor was er ruimte op bedrijven om te investeren. ${ }^{20}$

Het toegekende bedrag was ruim $€ 21 \mathrm{mln}$. in de periode 2016 tot en met 2018 (bijlage 3, tabel B3.1). Dit is bijna $60 \%$ van het totale bedrag begroot door de provincies bij aanvang van POP3 (35,76 mln., zie bijlage 5, en ook eind 2018 nog steeds het begrote bedrag).

In Noord-Brabant is het grootste bedrag verleend namelijk bijna $€ 3 \mathrm{mln}$. (zie figuur 4.1). De regeling is succesvol wat betreft de uitputting van het budget, enkel de provincie Limburg heeft het beschikbaar gestelde budget niet uitgeput. Het is niet precies duidelijk wat de achterliggende oorzaken hiervoor zijn. Het gemiddeld verleende bedrag per aanvraag bedroeg $€ 17.000$ bij een maximum van $€ 20.000$ en een minimum van $€ 10.000$.

Het totaal beschikbare budget voor de gehele periode bedraagt $€ 35,76 \mathrm{mln}$. Gezien de grote belangstelling voor de gehouden openstellingen, en ook voor de lopende $4^{\mathrm{e}}$ openstelling (750 aanvragen ter beoordeling), is de verwachting dat het gehele bedrag wordt uitgeput.

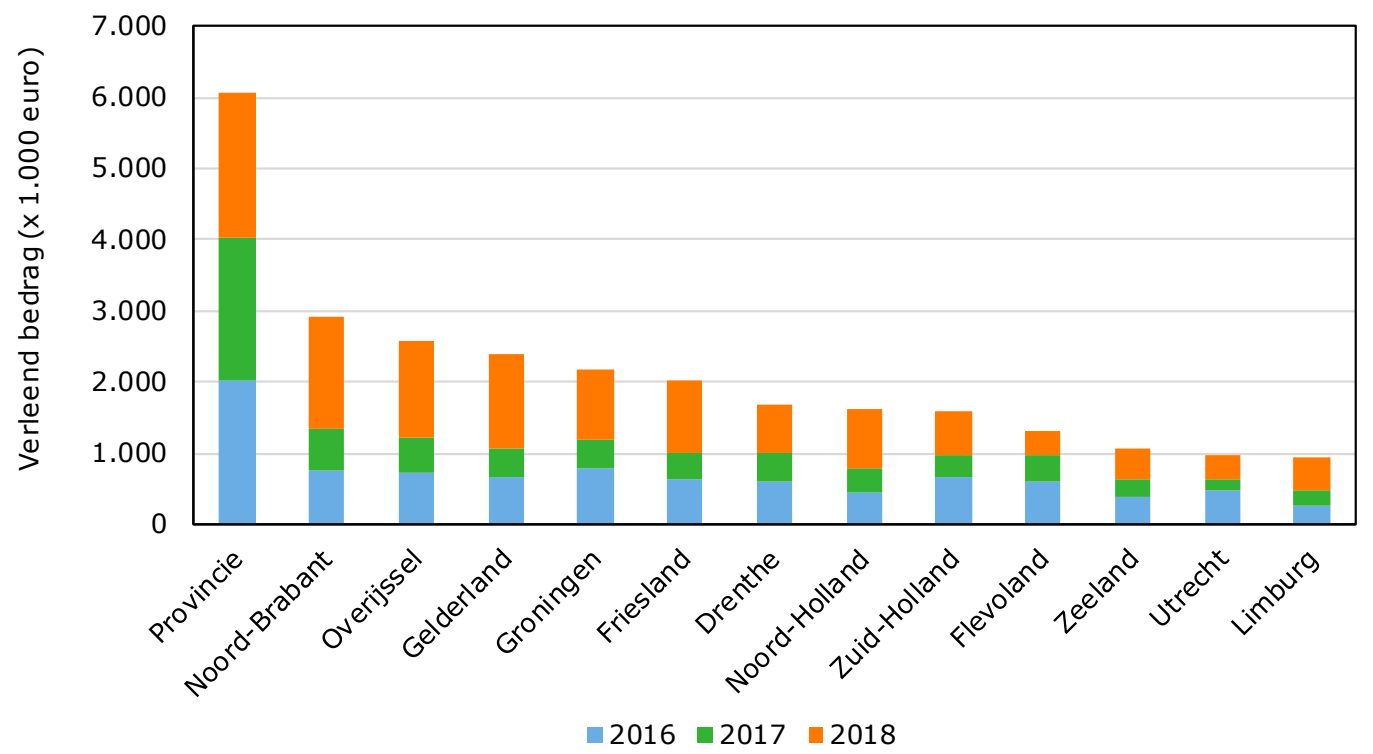

Figuur 4.1 Verleend bedrag Jonge landbouwers-regeling per provincie, 2016 tot en met 2018

Op het moment van aanvragen was bijna de helft van de aanvragers van de Regeling Jonge Landbouwers tussen de 35 en 40 jaar oud. Een kwart van de aanvragers was tussen de 30 en 35 jaar (figuur 4.2). Dit laat zien dat jonge ondernemers vooral een aanvraag JoLa doen in de eindfase van de maatschap met ouders, maar vooral ook in de eerste jaren na de bedrijfsovername. Ook de fases in en na het overnameproces waarin de jonge ondernemer grotendeels of geheel de regie heeft over de strategie en bedrijfsvoering.

\footnotetext{
${ }^{19}$ Ieder jaar komen er ongeveer 800 potentiële bedrijfsopvolgers bij. Veronderstellende dat deze regeling een structureel karakter heeft, dan zou over de periode 2016 tot en met 2018 (met 1.248 toegewezen aanvragen) ongeveer de helft van de jonge opvolgers een beroep doen op deze regeling. Indien rekening wordt gehouden dat de eerste jaren van POP3 geen openstelling is geweest, en rekening houdend met het begrote budget voor deze maatregel over de POP3-periode (bijlage 5) dan komt dit \% aanzienlijk lager uit.

${ }^{20}$ Voor de $4^{\mathrm{e}}$ openstelling JoLa, die eind 2018 startte en eindigde begin 2019, zijn 750 aanvragen binnengekomen bij RVO. De interesse onder jonge boeren voor deze regeling is onverminderd groot.
} 


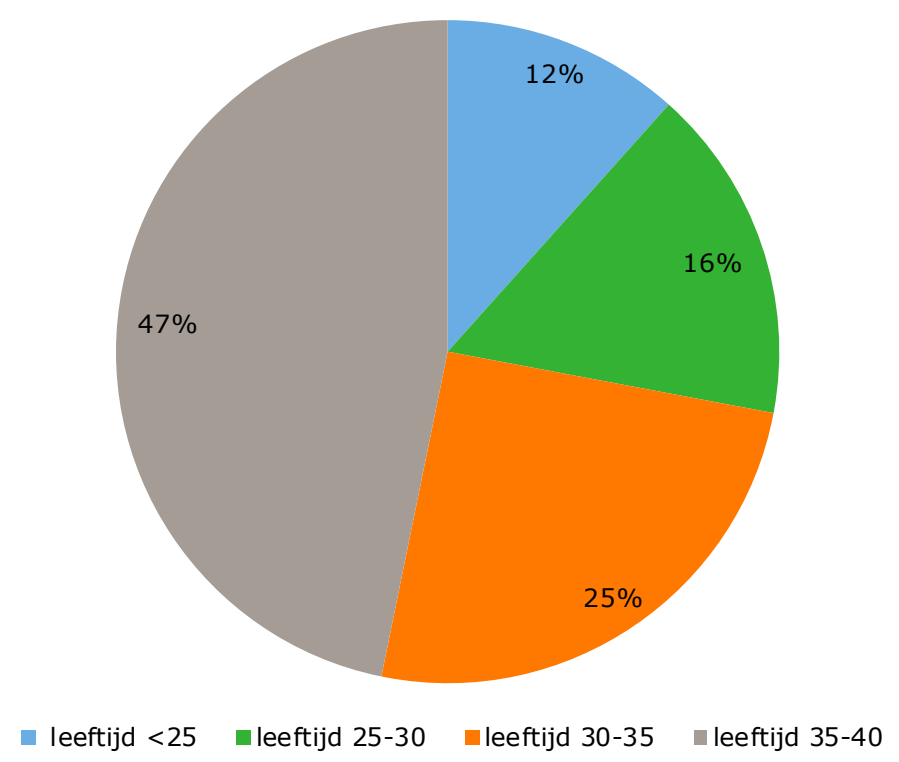

Figuur 4.2 Verdeling aantal aanvragen Jonge landbouwers-regeling naar leeftijdscategorie aanvrager, 2016 tot en met 2018

Bron: RVO, bewerking Wageningen Economic Research.

Er zijn ruim 20 investeringscategorieën onderscheiden in de regeling. ${ }^{21}$ Van de mogelijkheid om te investeren in zonnepanelen is veruit het meest gebruik gemaakt ( $45 \%$ van het totale budget, zie figuur 4.3). In de categorie 'overig' zijn de resterende investeringscategorieën opgenomen die individueel allemaal een aandeel van minder dan $4 \%$ in het totaal hebben. In bijlage 3 is de verdeling naar provincies opgenomen.

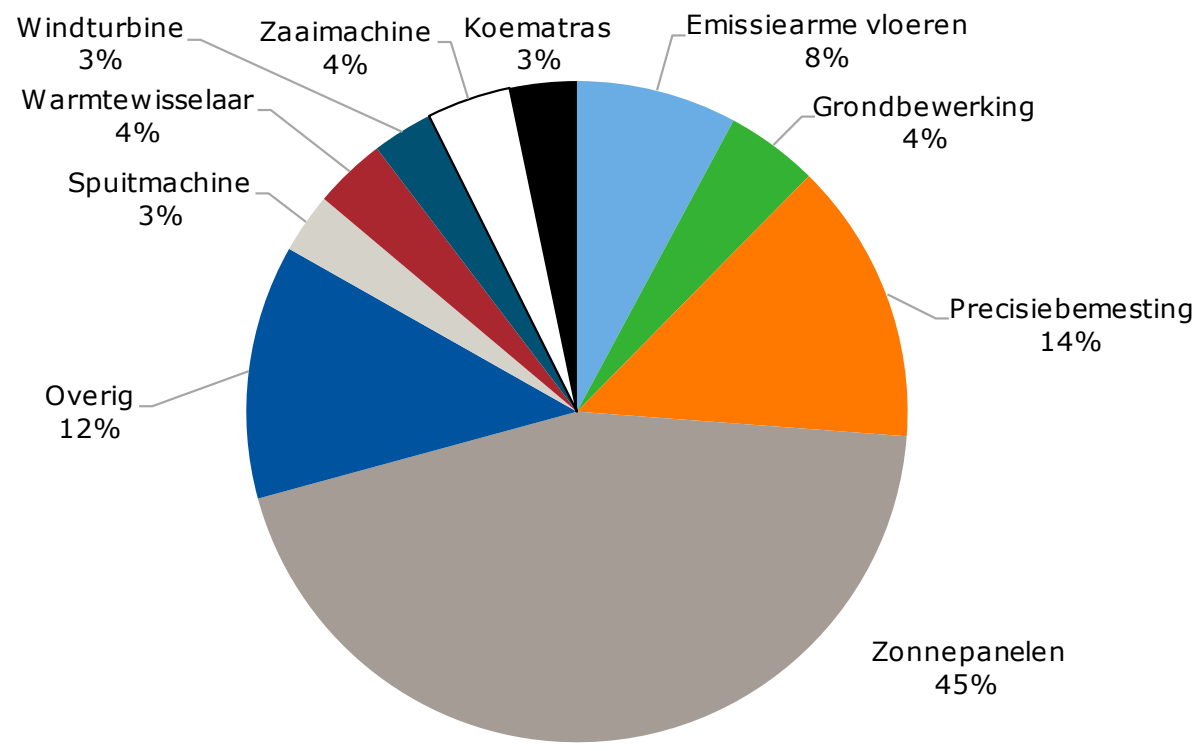

Figuur 4.3 Verdeling verleende bedragen Jonge landbouwers-regeling naar belangrijkste investeringscategorieën, 2016 tot en met 2018 Bron: RVO, bewerking Wageningen Economic Research.

\footnotetext{
${ }^{21}$ Op een aantal categorieën op de investeringslijst is uiteindelijk niet ingeschreven.
} 


\subsection{Doeltreffendheid}

Hierbij is gebruikgemaakt van een enquête onder de subsidieontvangers en diepte-interviews met subsidieadviseurs en belangenorganisaties.

De enquête is alleen gehouden onder de subsidieontvangers. De beantwoording van de enquêtevragen van in de JoLa geïnteresseerde jonge ondernemers die geen geschikte investeringscategorie konden vinden die op hun behoefte aansluit, of waarvan een aanvraag is afgewezen vanwege het vol zijn van het beschikbare budget per openstelling, kan anders uitpakken. Zie ook NAJK, 2016.

\subsubsection{Resultaten enquête en bevindingen interviews ${ }^{22}$}

$\mathrm{Er}$ is een enquête ${ }^{23}$ uitgezet onder ondernemers waarvan een JoLa-regeling aanvraag uit de $3^{e}$ openstelling (december 2017-januari 2018) is toegewezen. De reden om ons tot deze openstelling te beperken zijn de al beschikbare analyses van de $1^{\text {e }}$ openstelling en de doorgevoerde wijzigingen naar aanleiding van de uitkomsten van de evaluatie door Bureau Bartels (2016).

De respons op de enquête bedroeg $37 \%$ en heeft geleid tot 111 volledig ingevulde enquêtes. De belangrijkste overzichten van resultaten worden vermeld in deze paragraaf; de overige resultaten staan in bijlage 3 (figuren die beginnen met B3.).

Respondenten zijn ingedeeld naar sector, provincie en leeftijd op moment van aanvragen. Tabel 4.2 geeft de respons per groep.

Tabel 4.2 Respons enquête naar subgroep a)

\begin{tabular}{lr} 
Categorie & 35 \\
Leeftijd & 29 \\
$<30$ & 47 \\
$30-35$ & 102 \\
$>35$ & 17 \\
\hline Sector $b$ ) & \\
Intensieve veehouderij & 63 \\
Melkveehouderij & 22 \\
Akkerbouw & 111 \\
\hline Regio $c$ ) & 25 \\
West & 24 \\
Zuid & 35 \\
Oost & 27 \\
Noord & \\
\hline
\end{tabular}

a) In verband met de response (en daarmee de steekproefgrootte) en de mogelijkheden voor analyses, sluit de indeling niet geheel aan bij de bestuurlijke indeling, waarbij Flevoland tot West gerekend wordt; b) Het resultaat van de sector 'overige landbouw' is niet afzonderlijk opgenomen in de figuren, vanwege het kleine aantal respondenten (9). De glastuinbouw en overige tuinbouw zijn niet vertegenwoordigd in de responsgroep. RVO beschikt niet over informatie uit welke sector de goedgekeurde aanvragen afkomstig zijn, waardoor er geen uitspraken over de representativiteit naar sector kan worden gedaan; c) Noord: Friesland, Drenthe, Groningen. Oost: Flevoland, Gelderland, Overijssel. West: Noord-Holland, Zuid-Holland, Utrecht. Zuid: Zeeland, Noord-Brabant, Limburg.

In de resultaten van de enquête worden regio en bedrijfstype onderscheiden. Bij de interpretatie van de resultaten is het van belang om te weten hoe de sectoren over de regio's zijn verdeeld. Melkveehouderij is in alle regio's in sterke mate aanwezig. In Oost is er een behoorlijk aandeel intensieve veehouderij. In Zuid is ook de akkerbouw belangrijk. ${ }^{24}$ Opvallend is het relatief lage

\footnotetext{
${ }^{22}$ Zie bijlage 3 voor een overzicht van de geïnterviewde personen.

${ }^{23}$ Zie bijlage 3 voor de opzet van de enquête.

${ }^{24}$ Mede door het ontbreken van geschikte investeringscategorieën voor intensieve veehouderijbedrijven op de investeringslijst van de provincie Noord-Brabant zijn intensieve veehouderijbedrijven in deze provincie ondervertegenwoordigd.
} 
aandeel intensieve veehouderij in Zuid. Dit heeft mede te maken dat bijvoorbeeld Noord-Brabant de investeringslijst zodanig heeft ingeperkt, dat er minder passende investeringsmogelijkheden voor deze sector aanwezig waren (zie figuur 4.4). Dit wordt ook door geïnterviewden aangegeven.

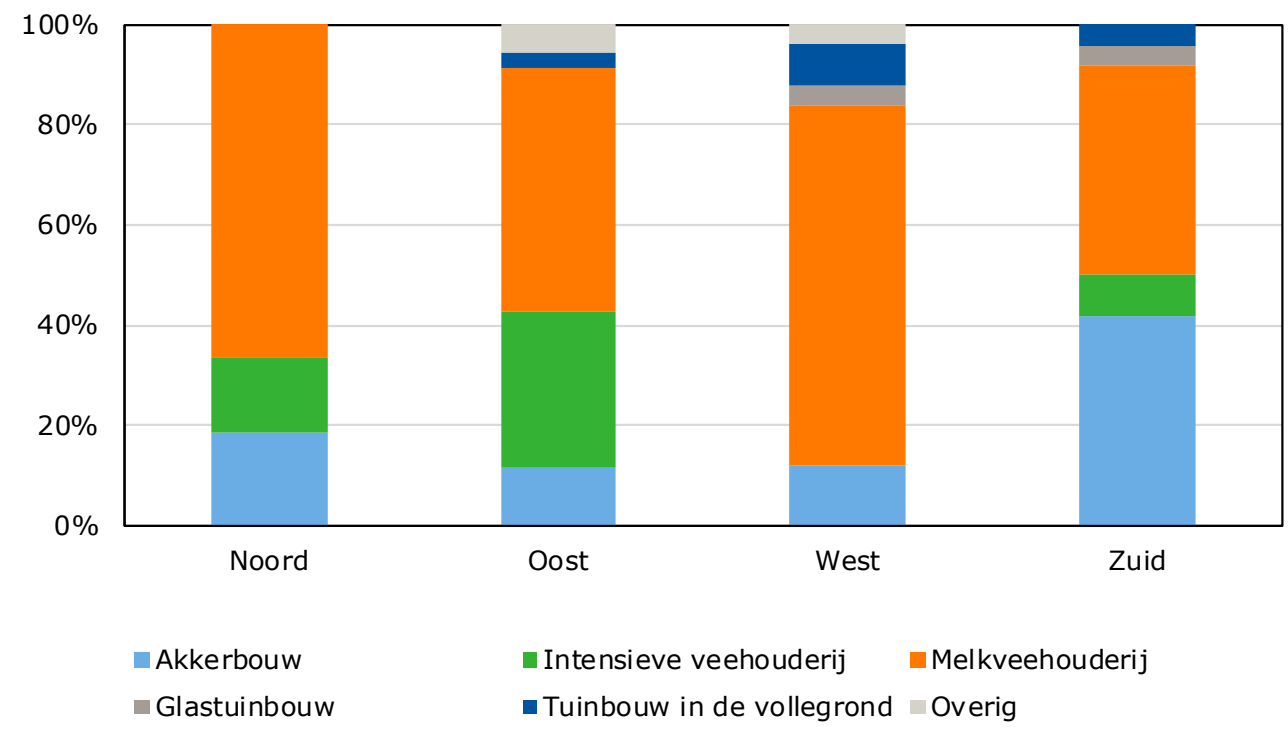

Figuur 4.4 Verdeling respondenten naar sector en regio

De meerderheid van de respondenten (62\%) vindt dat de JoLa-regeling 'zeer goed' tot 'goed' aansluit bij de persoonlijke investeringsbehoeften (figuur B3.1). De akkerbouwers waren positiever gestemd dan ondernemers in de andere sectoren. In regio Oost bleef de tevredenheid achter ten opzichte van de andere regio's. Mogelijke verklaring hiervoor is het grote aandeel veehouderij in deze regio. De tevredenheid varieerde niet veel tussen de verschillende leeftijdscategorieën.

De mening van jonge ondernemers die niet konden inschrijven omdat er geen passende investeringscategorie (binnen de openstellingen van fysieke regeling binnen hun provincie) was, zal heel anders zijn. Dit zal het geval zijn bij vooral intensieve veehouders in Noord-Brabant.

De geïnterviewden geven aan dat de investeringscategorieën ten dele aansluiten bij de behoefte van de boer en tuinder. Door het benoemen van zeer specifieke investeringen op een investeringslijst sluit het lang niet altijd aan bij de behoefte van de jonge boer in alle land- en tuinbouwsectoren. In een periode waarin de financiering van de bedrijfsovername centraal staat hebben veel boeren behoefte aan investeringen die aansluiten bij de (basis)bedrijfsvoering. Hier staat tegenover dat in Nederland alleen bovenwettelijke inspanningen/investeringen op de investeringslijst mogen, en dat provincies vanuit hun beleid nog kunnen sturen of ze bepaalde categorieën investeringen erbuiten laten.

De investering die mede met financiering vanuit de JoLa-regeling is gedaan is door meer dan $80 \%$ van de respondenten als 'zeer belangrijk' of 'belangrijk' bestempeld (figuur 4.5). Ook hier was de akkerbouw positiever dan de andere sectoren. 


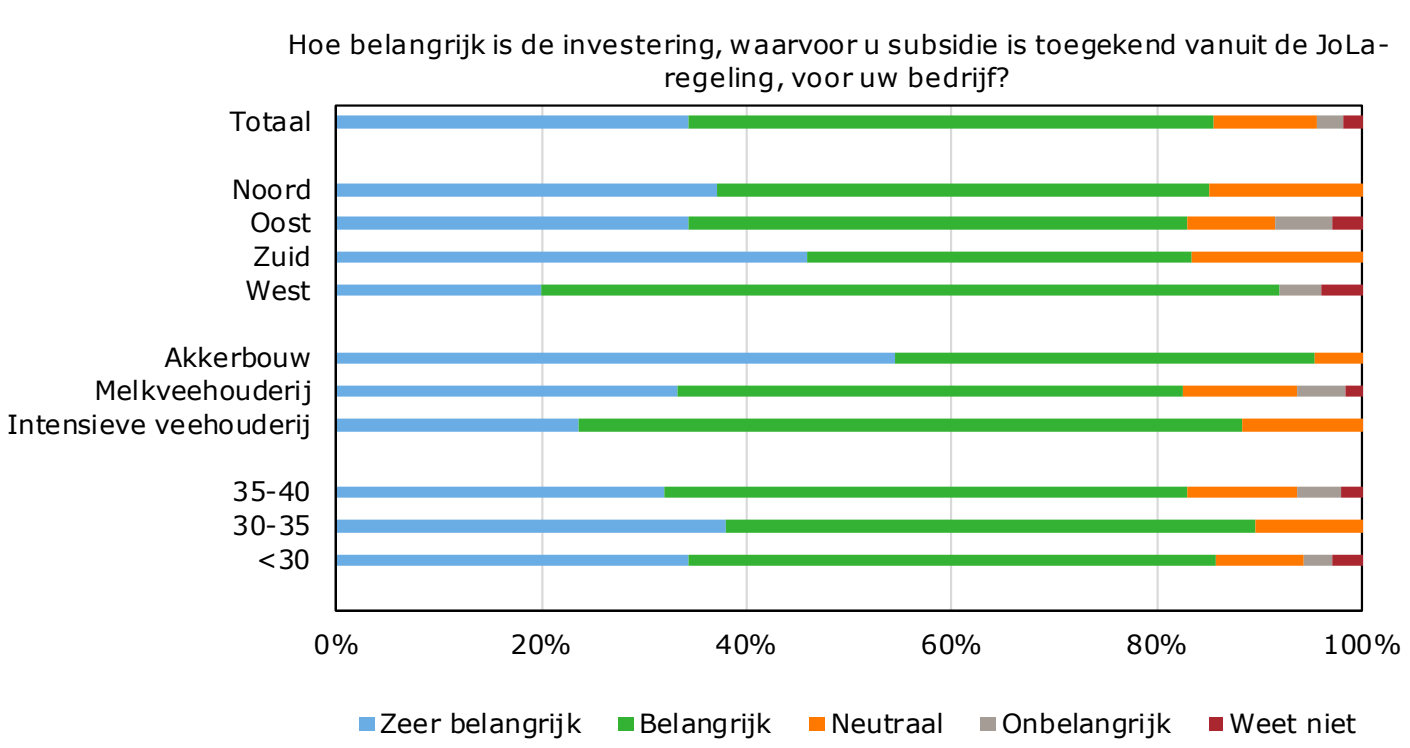

Figuur 4.5 Enquête: Belang van de JoLa-regeling voor investering op het bedrijf

Met betrekking tot de uitvoering van de investering met de subsidie vanuit de JoLa-regeling zijn in de enquête een aantal stellingen voorgelegd (zie bijlage 3 voor de figuren). Resultaten stellingen:

- 75\% van de respondenten gaf aan dat door de subsidie het investeringsproject doorgezet kon worden (figuur B3.2). In de intensieve veehouderij was dit beduidend lager.

- Iets minder dan de helft van de respondenten vond dat door de subsidie er eerder gestart kon worden met het investeringsproject (figuur B3.3). Voor de akkerbouw gold dat meer dan $80 \%$ de stelling positief beantwoordde. In de melkveehouderij en intensieve veehouderij was dit rond de $40 \%$. Van de groep jongste ondernemers ( $<30$ jaar) vond 35\% dat er eerder gestart kon worden. Bij de andere leeftijdscategorieën lag dit rond de $50 \%$.

- Iets meer dan $60 \%$ van de respondenten was het 'zeer eens' of 'eens' met de stelling dat de kwaliteit van het investeringsproject kon worden verhoogd met behulp van de JoLa-regeling (figuur B3.4). Bij de akkerbouw was ruim $90 \%$ dit van mening. In regio zuid was men hier in sterkere mate mee eens dan in de andere regio's.

- Van de respondenten gaf $43 \%$ aan 'neutraal' te zijn op de stelling dat het project grootschaliger kon worden opgepakt (figuur B3.5). In regio Oost was men het wel vaker 'eens' of 'zeer eens' met de stelling dan in andere regio's.

- Iets meer dan $40 \%$ van de respondenten kon met behulp van de JoLa-regeling het investeringsproject versnellen (figuur B3.6). In regio West was een beduidend groter deel van de respondenten het eens met de stelling dan in regio Noord. De groep $<30$ was het minder vaak eens met de stelling dat de ondernemers in de andere leeftijdscategorieën.

Een minderheid (12\%) van de respondenten was het 'eens' of 'zeer eens' met de stelling dat de JoLaregeling geen meerwaarde had voor de investeringen die zijn gedaan (figuur 4.6). Voor het overgrote deel van de respondenten was er een meerwaarde. In de akkerbouw was het aandeel die de meerwaarde ondervond groter dan in de veehouderijsectoren. Tussen regio's en leeftijdscategorieën waren de verschillen beperkt, al was men in Oost en Zuid minder overtuigd van de meerwaarde. Cijfers uit de eerste openstelling geven eenzelfde beeld (Bureau Bartels, 2016). 


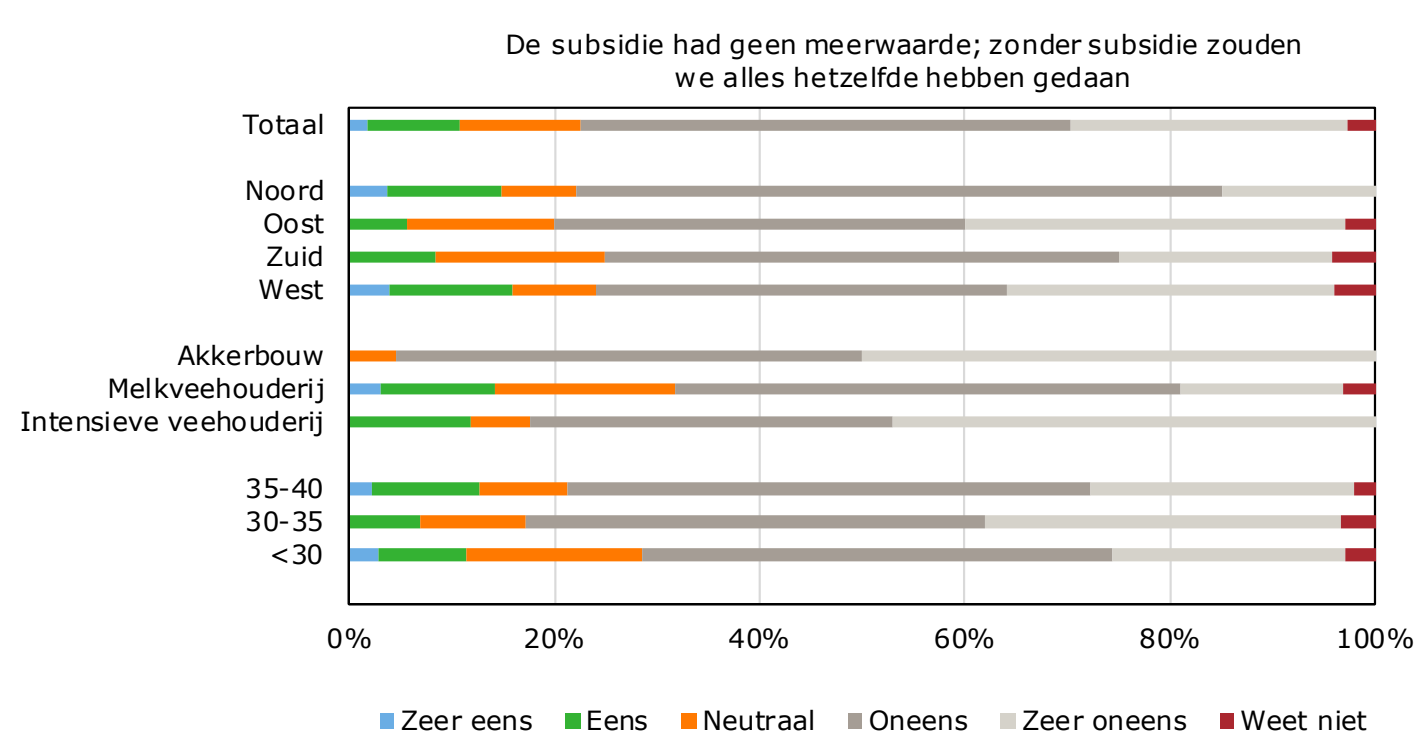

Figuur 4.6 Enquête: Subsidie had geen meerwaarde

Volgens een gering aandeel (10\%) van de respondenten was het effect van de JoLa-regeling 'groot' op de verhoging van de omzet (figuur B3.7). Daartegenover vond $4 \%$ dat er een negatief effect was op de verhoging van de omzet. Dit heeft mede te maken met het minder passen van de investering met de basis bedrijfsvoering, en het bovenwettelijke karakter.

Ongeveer 1 op de 5 respondenten vond het effect van de JoLa-regeling op de verlaging van de productiekosten 'zeer groot' of 'groot' (figuur B3.8). In Zuid was men hierover minder positief dan in de andere regio's. In de akkerbouw waren de ondernemers het in sterkere mate eens met de stelling dan in de veehouderij.

De geïnterviewde adviseurs en belangenbehartigers bevestigen het beeld uit deze enquête dat de JoLa-regeling slechts beperkt bijdraagt aan het verbeteren van de concurrentiekracht (gedefinieerd als het verhogen van de omzet en/of verlagen van de productiekosten) Daar is het subsidiebedrag van maximaal $€ 20.000$ in relatie tot kapitaalsbehoefte bij de overname te gering voor. Daarnaast hangt de bijdrage af van de gekozen investeringen uit de lijst. Bijvoorbeeld precisielandbouw draagt direct bij aan het primaire productieproces en zo ook aan economische prestaties. Volgens de geïnterviewden zorgt de regeling er met name voor dat investeringen in de tijd naar voren worden gehaald. De subsidie werkt drempelverlagend. Hierbij aangetekend dat de investering wel moet wel passen binnen de strategie van het bedrijf.

De duurzaamheid van het bedrijf werd verbeterd door de JoLa-regeling volgens $80 \%$ van de respondenten (figuur 4.7). De akkerbouw was het hier in sterkere mate mee eens dan de andere sectoren. Een beperkt deel van de respondenten ervaarde een negatief effect op de duurzaamheid. Dit heeft mede te maken dat de investeringslijsten niet altijd goed aansluiten op de basis bedrijfsvoering van een bedrijf. Voor meerdere (potentiële) opvolgers is de financiering van de overnamesom al een hele moeilijke uitdaging, gepaard gaande met zware financieringslasten en daarmee druk op het gezinsinkomen. Een extra financiering in een bovenwettelijke investering leidt voor een deel van de bedrijven tot een verdere verzwaring van de financieringslasten. Immers het overgrote deel van de investering met JoLa-subsidie moet zelf worden gedragen.

Volgens de respondenten was de JoLa-regeling goed voor de modernisering van het bedrijf, $70 \%$ beschouwde het effect als 'zeer groot' of 'groot' (figuur B3.9). De akkerbouwers waren het hier in sterkere mate mee eens dan in de veehouderij. Geïnterviewden bevestigen de bijdrage van de investeringslijst aan de modernisering in de akkerbouw en zijn kritisch op de lijst en bijdrage voor de veehouderijsectoren. In regio Zuid was de instemming hoger dan in de andere regio's. 
Effecten op de prestaties en continuïteit: verbetering van de duurzaamheid van het bedrijf

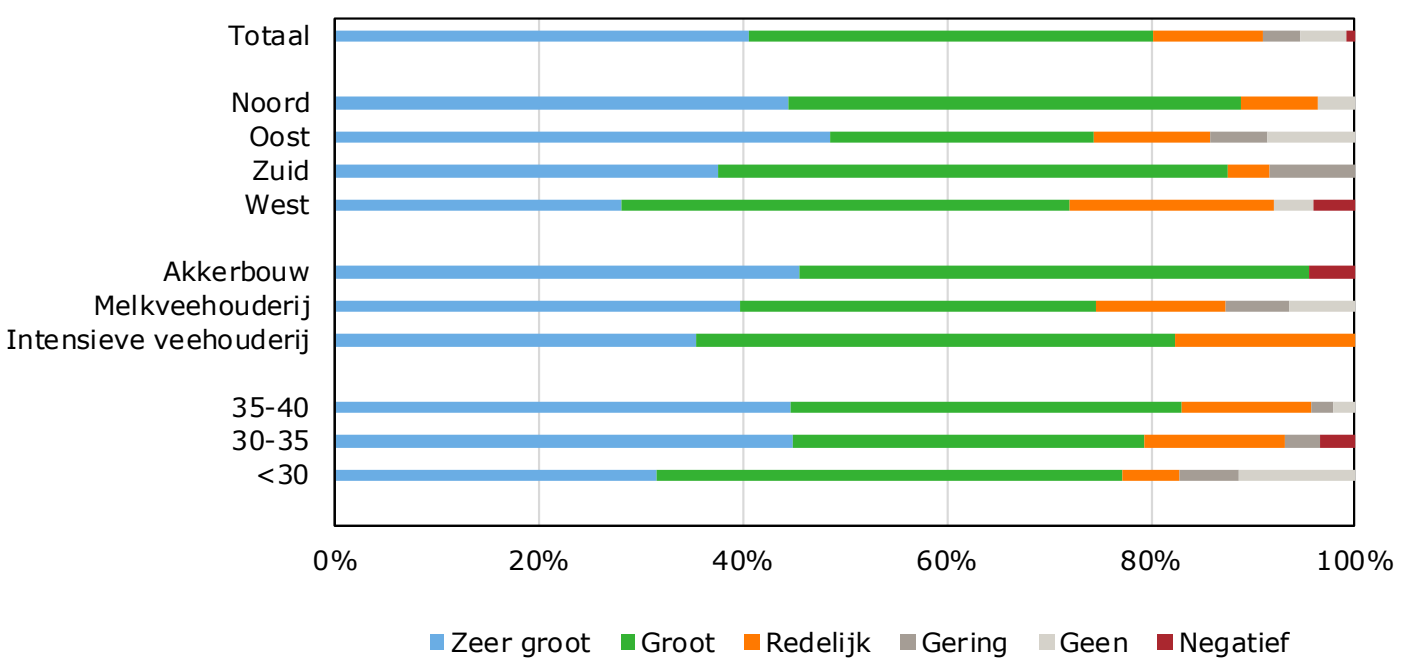

Figuur 4.7 Enquête: Verbetering duurzaamheid van het bedrijf

Het effect van de JoLa-regeling op het besluit om het bedrijf over te nemen was voor een minderheid van de respondenten 'zeer groot' of 'groot' (figuur B3.10). Voor de meerderheid was het effect 'gering' of was er 'geen' effect. Dit beeld wordt bevestigd vanuit de interviews. Zij geven aan dat het bedrag beperkt is in relatie tot de overnamesom. De oudere generatie binnen de maatschap profiteert ook van de subsidieaanvraag van de jonge boer. Pas na de overname heb je als jonge boer de vrije hand in de bedrijfsvoering. Keerzijde is wel dat hiermee voor de overname bedrijf op orde is maar dan moet de investering wel passen in het beeld van de ouders. Voor ondersteuning van de generatie-wissel was de 'oude' regeling onder POP2 beter. Onder die regeling was het niet mogelijk om in maatschapsverband met de ouders deel te nemen aan de JoLa-regeling. Overigens was daar het probleem dat je de aanvraag moest indienen in de eerste 3 jaar na de overname.

Een ruime meerderheid van $80 \%$ van de respondenten hecht 'zeer groot' tot 'groot' belang aan voorzetting van de JoLa-regeling voor de toekomst van de jonge landbouwers (figuur 4.8). Dit beeld komt overeen met uitkomsten van de enquête gehouden onder de aanvragers van de eerste openstelling (Bureau Bartels, 2016). In de melkveehouderij werd dit belang kleiner geacht dan in de akkerbouw en intensieve veehouderij. Ook vanuit de geïnterviewden wordt het belang van continuering van de JoLa-regeling onderschreven. De regeling geeft de ondernemers een steuntje in de rug om het bedrijf toekomstbestendiger te maken.

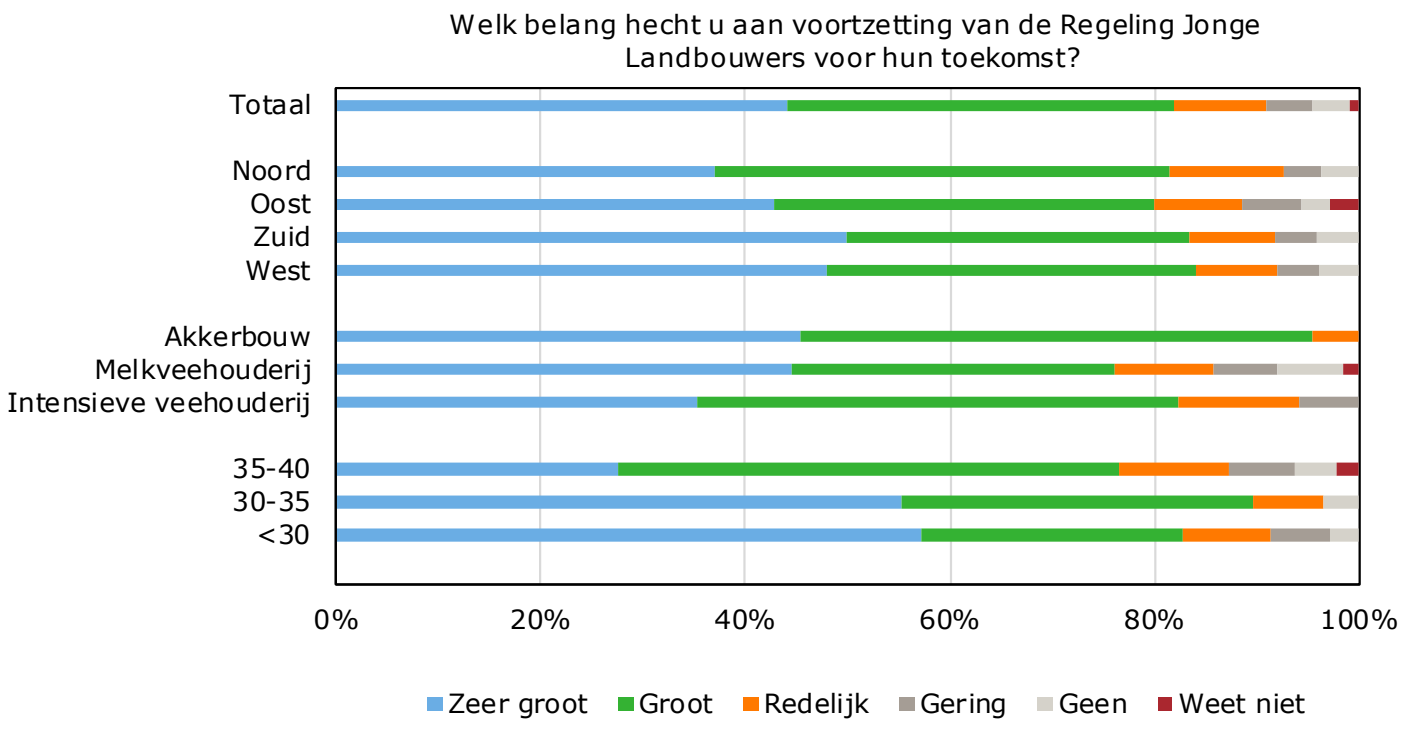

Figuur 4.8 Enquête: Belang JoLa-regeling voor toekomst jonge landbouwer 
Een belangrijk deel van de geïnterviewden noemt als eventueel wenselijke aanpassingen in de inhoud van de JoLa-regeling de behoefte aan een generieke regeling met ruimer budget voor jonge boeren gericht op de bedrijfsovername. 25 Hierbij is het NAJK voorstander om de subsidie alleen beschikbaar te stellen voor jonge boeren na de bedrijfsovername zodat de jonge boer zelf kan beslissen waarin er wordt geïnvesteerd. Dus niet zoals nu de mogelijkheid om het in maatschapsverband aan te vragen. Daarnaast wordt gepleit voor met name aanpassingen in de investeringslijst, en dat er geen sectoren buiten de boot vallen, zoals nu de geitenhouderij, en sommige sectoren door stringent provinciaal beleid.

Investeringen op de lijst staan te ver af van het primaire proces, zeker voor de veehouderij. Ook kleine sectoren, zoals boomkwekerij en melkgeiten hebben moeite om geschikte investeringen te vinden op de lijst. Sommigen zijn nog niet toe aan investeren in bijvoorbeeld zonnepanelen. Eerst de basale zaken gericht op het productieproces op orde krijgen als jonge boer. Ook de verschillen tussen provincies die investeringscategorieën van hun lijst/openstelling kunnen schrappen remt de ontwikkeling van jongen boeren in sommige bedrijfstakken in sommige provincies. Bijvoorbeeld Noord-Brabant waar de provincie investeringen voor varkenshouderij heeft geschrapt.

Daarnaast zijn sommige geïnterviewden voorstander van het loslaten van een investeringslijst en in plaats daarvan te werken met 'kaders' gericht op duurzaamheid na de bedrijfsovername waarbinnen investeringen moeten plaatsvinden. Uit de evaluatie van de eerste openstelling in 2016 door Bureau Bartels blijken het Regiebureau POP en de provincies bewust te hebben afgezien van deze variant vanwege de daarmee gepaard gaande hoge(re) uitvoeringskosten.

Jonge boeren in de provincie Noord-Holland zijn positief gestemd over een ingericht landbouwportaal binnen hun provincie. Ondernemers kunnen hier hun investeringsinteresse kenbaar maken, waarna vervolgens samen met een coach gekeken wordt welke subsidieregelingen er zijn en wat voor hun mogelijk interessant is. Ervaringen hiermee zijn positief.

Tabel 4.3 Bijdrage JoLa aan de algemene evaluatievragen EU (bijvangst, zie ook bijlage 7)

\begin{tabular}{ll} 
Algemene vragen & Maatregel Jonge landbouwers \\
$\begin{array}{l}\text { Bevordering concurrentievermogen } \\
\text { agrarische sector }\end{array}$ & $\begin{array}{l}\text { Het effect van de JoLa-regeling op de verhoging van de omzet of het } \\
\text { verlagen van de productiekosten werd niet heel groot geacht, gezien ook het } \\
\text { karakter van de investeringen (bovenwettelijk, minder passend bij de } \\
\text { normale bedrijfsvoering). }\end{array}$ \\
\hline $\begin{array}{l}\text { Bevorderen van innovatie in agrarische } \\
\text { sector }\end{array}$ & $\begin{array}{l}\text { De investeringen hebben een duidelijk effect op verduurzaming van het } \\
\text { productieproces en op de moderniteit van het bedrijf. Gezien de hoogte van } \\
\text { de investeringsbedragen is er een klein innovatief effect, mede omdat het } \\
\text { bovenwettelijke investeringen betreft. }\end{array}$ \\
\hline $\begin{array}{l}\text { Waarborgen duurzaam beheer natuurlijke } \\
\text { hulpbronnen en klimaatactie }\end{array}$ & $\begin{array}{l}\text { Een aantal categorieën waarin geïnvesteerd is, draagt bij aan duurzaam } \\
\text { beheer en klimaat. Zo betrof 45\% van de goedgekeurde aanvragen }\end{array}$ \\
\hline
\end{tabular}

\subsection{Doelmatigheid}

Over de uitvoering van de JoLa-regeling is onder andere naar voren gebracht dat de aanvraag eenvoudiger zou moeten worden zodat meer jonge boeren de aanvraag zelf kunnen doen. De huidige aanvraag moet op het eigen BSN van de jonge boer. De suggestie is gedaan om de aanvraag te kunnen doen op het bedrijfsnummer zoals ook al bekend bij RVO, en dan vervolgens toewijzen aan de jonge boer. Er is ook behoefte aan meer duidelijkheid over de inhoud en momenten van openstelling. Dit is opvallend, omdat 3 van de 4 openstellingen hebben plaatsgevonden in de periode decemberjanuari.

\footnotetext{
${ }^{25}$ In 2019 treedt naar verwachting het bedrijfsovernamefonds in werking. Dit fonds richt zich zowel op de invoering van een garantieregeling voor financiering duurzame investeringen in een situatie met onvoldoende (financiële) zekerheden (in eerste drie jaar na overname) als op het ondersteunen van coaching en opleiding.
} 
Daarnaast wordt de drempel van het minimum subsidiebedrag van $€ 10.000$ als belemmerend ervaren. ${ }^{26}$

De relatief lage subsidiebedragen brengen ook met zich mee dat de administratieve lasten en uitvoeringskosten (in \% van de subsidie) relatief hoog zijn.

\subsection{Conclusies en aanbevelingen}

- In de periode 2016 tot en met 2018 (de eerste 3 openstellingen) waren er 1.248 toegewezen aanvragen van de JoLa-regeling. Hiervan hadden er 581 (iets minder dan helft) betrekking op 2018. Het toegekende bedrag was ruim $€ 21 \mathrm{mln}$. In Noord-Brabant is het grootste bedrag verleend namelijk bijna $€ 3 \mathrm{mln}$. De provincie Limburg is de enige provincie geweest waarbij het beschikbaar gestelde budget niet was uitgeput. Het totaal beschikbare budget voor de gehele periode bedraagt $€ 35,76 \mathrm{mln}$. Gezien de grote belangstelling voor de gehouden openstellingen is de verwachting dat het gehele bedrag wordt uitgeput.

- Het gemiddeld verleende bedrag per aanvraag bedroeg $€ 17.000$ bij een maximum van $€ 20.000$ en een minimum van $€ 10.000$.

- Op het moment van aanvragen was bijna de helft van de aanvragers van de Regeling Jonge Landbouwers tussen de 35 en 40 jaar oud.

- Er zijn ruim 20 investeringscategorieën onderscheiden in de regeling. Van de mogelijkheid te investeren in zonnepanelen is veruit het meest gebruik gemaakt (45\% van het totale budget).

- Het bereik is groot in vergelijking met de streefwaarden. Toch bereikt de JoLa-regeling lang niet alle jonge ondernemers.

- Deelnemers met een toegekende subsidie vinden in meerderheid (62\%) dat de JoLa-regeling goed aansluit bij de persoonlijke investeringsbehoefte. In de akkerbouw sloot het beter aan dan bij de veehouderij. In regio Oost werd de aansluiting het minst goed beoordeeld, mogelijk mede doordat de akkerbouw in deze regio van geringer belang is dan in de andere regio's. Uit de interviews komt naar voren dat er meer aandacht nodig is voor passende investeringen voor met name kleine sectoren, voor type investeringen die beter aansluiten bij het primaire proces (zeker in deze fase van het ondernemerschap erg belangrijk gezien de financiële lasten van een overname) en dat door beleid van een aantal provincies bepaalde groepen jongeren niet in aanmerking komt.

- Van de ontvangers vindt $86 \%$ dat de toegekende subsidie via de JoLa-regeling 'zeer belangrijk' of 'belangrijk' is om duurzame investeringen te kunnen doen in het bedrijf. Een klein deel van de ondernemers had zonder de JoLa-regeling dezelfde investeringen uitgevoerd als met de JoLa-regeling.

- Het effect van de JoLa-regeling op de verhoging van de omzet of het verlagen van de productiekosten werd niet heel groot geacht, gezien ook het karakter van de investeringen (bovenwettelijk, minder passend bij de normale bedrijfsvoering). Wel was er een duidelijk effect op de duurzaamheid en moderniteit van het bedrijf.

- De grote meerderheid van de respondenten hecht een groot belang aan continuering van de JoLaregeling voor de toekomst van de jonge landbouwer. De subsidie wordt gezien als belangrijk steuntje in de rug.

- Het effect van de JoLa-regeling op het besluit om het bedrijf over te nemen was voor de meerderheid 'gering' of er was 'geen' effect. De subsidie is gering in vergelijking tot de financiering van de overnamesom van het bedrijf. Daarnaast zal een deel van de bedrijven moeite hebben de extra (eigen) financiering van de bijkomende JoLa-investering te dragen.

Aanbevelingen voor toekomstige openstelling van de JoLa-regeling:

- De 'basis' investeringslijst constant houden en investeringscategorieën toevoegen met meer oog voor de 'kleine', specifieke deelsectoren.

- Mogelijkheden onderzoeken om via verschuivingen extra budget toe te delen aan deze regeling, gezien de grote interesse, en daarmee vergroting van het bereik onder jonge agrariërs.

- In de communicatie sterker benadrukken dat Nederland heeft gekozen voor duurzaamheidsbevordering met als randvoorwaarde investeringen die bovenwettelijk zijn.

\footnotetext{
${ }^{26}$ In de praktijk komt enige flexibiliteit voor indien door goed onderhandelen van de ondernemer (aanvrager) de betaalde subsidie net onder de minimumgrens uit komt.
} 


\section{$5 \quad$ Verbetering verkaveling (maatregel 4.3)}

Belangrijkste bevindingen

Bereik en effectiviteit

- Voor maatregel Verbetering verkaveling is voor bijna $€ 28 \mathrm{~m} / \mathrm{n}$. aan subsidie verleend. Dit is ruim $55 \%$ van het bedrag dat de provincies eind 2018 hebben voorgesteld (bijna $€ 50 \mathrm{mln}$.). Bij de start van POP3 was ruim $€ 108 \mathrm{mln}$. begroot. Verandering van procedure (ten opzichte van POP2) en van prioritering beleidsdoelen waren hier vooral debet aan.

- Het aantal goedgekeurde aanvragen tot en met eind 2018 bedroeg 46. Dit is inclusief bedrijfsverplaatsingen. Noord-Holland verleende het hoogste bedrag aan subsidies, Limburg had het grootste aantal goedgekeurde aanvragen. Meerdere provincies hebben geen openstelling gedaan (Zuid-Holland en Noord-Brabant), of slechts voor een beperkt bedrag. De provincies Gelderland en Noord-Holland hebben ingezet op bedrijfsverplaatsingen in de glastuinbouw. Dit betrof in de periode 2014-2018 in Gelderland 11 bedrijven (met 17 aanvragen) met een goedgekeurd bedrag tot en met eind 2018 van $€ 4,19 \mathrm{mln}$. In Noord-Holland is voor $€ 4.440 .940$ goedgekeurd.

- Door de late opstart van nu nog lopende POP3-verkavelingsprojecten (vanaf 2016) zijn directe effecten nog niet meetbaar. De verwachting is dat de maatregel Verbetering verkaveling zal zorgen voor een betere verkavelingsstructuur op de deelnemende bedrijven. Dit zal leiden tot een lichte verbetering van inkomens (vooral lagere kosten, iets hogere opbrengsten) en bevordert daardoor ook het (opvolgings-)perspectief van agrarische bedrijven en draagt in beperkte mate bij aan de concurrentiekracht van de grondgebonden agrarische sectoren.

- Een betere verkaveling in de agrarische sector leidt tot milieuwinsten op een aantal vlakken;

- Bij projecten met meervoudige doelen (twee derde van de projecten) worden in sterke mate positieve effecten bereikt. Vooral natuur- en waterdoelen krijgen lokaal belangrijke impulsen mee. Ook verbetering van verkeersveiligheid zal in meerdere verkavelingsprojecten na afloop een belangrijk resultaat zijn.

- Een verplaatsingsregeling voor agrarische bedrijven wordt in Gelderland specifiek toegepast voor glastuinbouw. Deze regeling levert een versterking van de glastuinbouwstructuur op, en een substantiële bijdrage aan verduurzaming en versterking concurrentiekracht sector.

- De nieuwe moderne glastuinbouwbedrijven geven in doorsnee een positieve impuls aan kosten en opbrengsten en daarmee aan inkomens, bedrijfs- en opvolgingsperspectief. Dit, en meer concentratie qua ligging bij de ketenpartijen zal de concurrentiekracht versterken.

- De verplaatsingsregeling Glastuinbouw Gelderland heeft geleid tot een versterking van de ruimtelijke kwaliteit (minder sprokkellocaties glas).

\section{Doelmatigheid}

- Na enkele jaren ervaring opdoen loopt de tenderprocedure in meerdere provincies vanaf 2018 soepel(er).

- Door verandering in procedure zijn de aanvragen vooraf globaler uitgewerkt. Potentiele aanjagers (zoals landbouworganisaties) lopen minder hard voor indiening, in verband met risico op afwijzing bij tenderen. Er zijn nu veel minder vooraf goed uitgewerkte integrale gebiedsopgaven.

- De verruiming van de doorlooptijd naar 3 jaar wordt zeer positief beoordeeld.

- Verplaatsingsregeling glastuinbouw houdt goed rekening met bedrijfssituatie. Door lange duur van regeling kan verplaatsing beter aansluiten bij het afschrijvingsritme van kassen.

\section{Aanbeveling}

- Provincies kunnen meer de leerervaringen van tenderprocedures met elkaar delen.

- De praktijk heeft een sterke behoefte aan meer uniformiteit in procedures en openstellingen. 


\section{$5.1 \quad$ Beleidstheorie}

De maatregel is gericht op de verbetering van de bedrijfsvoering. Onder deze maatregel worden doelen nagestreefd als verbetering van de verkaveling (en daarmee de landbouwstructuur) en de bereikbaarheid van agrarische bedrijven, verbetering van de bodemgesteldheid en de waterhuishouding. Ook de verplaatsing van landbouwbedrijven uit het oogpunt van landbouwstructuur, milieu- en natuuroverwegingen valt hieronder.

Bij de start van POP3 is door de provincies voor $€ 118 \mathrm{mln}$. voor deze maatregel begroot. De provincie Gelderland heeft een deel van de beschikbare gelden ingezet op verplaatsing van glastuinbouwbedrijven.

De POP3-subsidie richt zich op kosten van het verkavelingsproces, proceskosten voor de planvorming en technische maatregelen (dempen/graven van sloten, lichte egalisatiewerkzaamheden, aanpassen van drainage, verbetering ontsluiting door aanleg weg, investeringen in energievoorziening of waterhuishouding met het doel om de duurzaamheid van de landbouw te vergroten). Ook worden inpassingsmaatregelen in acht genomen om negatieve effecten op de omgeving te verminderen. Bij bedrijfsverplaatsingen gaat het om de kosten van demonteren, verhuizen en weer opbouwen van installaties.

Er mag worden verwacht dat het verbeteren van de infrastructuur, afhankelijk van omvang en locatie van een goedgekeurd project, vooral positieve effecten op zal leveren. Een belangrijke voorwaarde voor goedkeuring van een aanvrage is dat een project aan bestaande wet- en regelgeving voldoet. Dit helpt mee negatieve effecten te beperken.

Deze maatregel Verbetering verkaveling, gericht op investeringen in infrastructuur, zal een bijdrage leveren aan prioriteit 2 van POP3 met als centrale evaluatievraag:

Leidt de inzet van de maatregel Verbetering verkaveling tot een duurzamere landbouw en verhoogt dit de inkomens en de concurrentiekracht van de Nederlandse grondgebonden landbouw?

Bij een verkaveling met een meervoudig doel (bijvoorbeeld agrarische structuurverbetering en water) zal bij een verplaatsing van een agrarisch bedrijf vanuit de overweging van water een te verwachten positief effect hebben op het doel water. Dit geldt ook voor natuur of andere doelen.

Een verbeterde kavelstructuur voor agrarische bedrijven op vrijwillige basis zal (volgens eerdere studies) leiden tot een efficiëntere bedrijfsvoering met positieve effecten op economie (lagere kosten voor transport en arbeid, mogelijkheden tot meer opbrengsten, bijvoorbeeld verkoop weidegang producten) en milieu (minder emissies op meerdere terreinen). Dit betekent dat ook de bodemkwaliteit, de waterkwaliteit en de luchtkwaliteit op en in de omgeving van het bedrijf zal verbeteren. Ofwel dit zal leiden tot een positieve impuls op het woon- en leefklimaat in de omgeving van het verkavelingsproject.

Verkaveling levert een belangrijke bijdrage aan de verkeersveiligheid in vele regio's op het platteland. Het aantal kilometers met landbouwvoertuigen op binnenwegen wordt er duidelijk door verminderd.

De Regeling Verplaatsing Glastuinbouw in Gelderland en de Regeling Verplaatsing

Glastuinbouwbedrijven in Noord-Holland, worden apart behandeld in paragraaf 5.5. 


\subsection{Bereik}

In het kader van de maatregel Verbetering verkaveling is voor bijna $€ 28 \mathrm{mln}$. aan subsidie verleend ${ }^{27}$ (zie bijlage 4 voor uitsplitsing per jaar en provincie). Dit is ruim 55\% van het bedrag dat de provincies eind 2018 hebben begroot voor deze maatregel. Opvallend daarbij is dat sinds de start van POP3 het begrote bedrag van ruim $€ 108 \mathrm{mln}$. met meer dan de helft is teruggebracht naar bijna $€ 50 \mathrm{mln}$. (bijlage 5). Het totale aantal aanvragen die eind 2018 zijn goedgekeurd bedroeg 46. Noord-Holland verleende het hoogste bedrag aan subsidies (zie figuur 5.1). Het grootste aantal goedgekeurde aanvragen had de provincie Limburg.

Opvallend is de afwezigheid van kavelruilprojecten met POP3-gelden in de provincies Noord-Brabant en Zuid-Holland. Laatstgenoemde provincie heeft een eigen provinciale regeling, die soms heel goed uitpakt. Uit interviews komt naar voren dat Noord-Brabant zodanige voorwaarden stelt, dat die voor agrariërs geen stimulans tot deelname zijn. Ook de provincies Groningen en Drenthe besteden een beperkt budget aan deze maatregel, veel minder dan bij aanvang POP3 begroot (bijlage 5). Drenthe wilde deze maatregel vooral benutten voor bedrijfsverplaatsingen. In de praktijk bleek dat de regeling niet goed aansluit bij de dynamiek rond bedrijfsverplaatsingen. Het budget is daardoor verlaagd.

Verkavelingsprojecten met POP3-middelen zijn pas sinds 2016 gestart en zijn nog in uitvoering. Er zijn dan ook geen harde realisatiegegevens beschikbaar om te evalueren. In bijlage 4, tabel B4.2, wordt een overzicht van verkavelingsprojecten in uitvoering gegeven per 1 juli 2018. Deze projecten beschikten over twee derde deel $(18,1 \mathrm{mln}$.) van het budget dat eind 2018 is goedgekeurd. Van de 23 projecten hebben er 14 (60\%) een meervoudig doel, waarvan 2 projecten natuur niet als doel hebben gesteld. In de tweede helft van 2018 is een grote inhaalslag gemaakt, en is voor bijna $€ 10 \mathrm{mln}$. aan POP3-subsidies goedgekeurd ( $€ 27,97 \mathrm{mln}$. minus $€ 18,1 \mathrm{mln}$.).

Het hoogste aantal beoogde hectares ruil vinden we terug in de provincies Friesland, Zeeland en Noord-Holland (bijlage 4, situatie per 1-7-2018). Het totale aantal beoogde hectares ruil in Nederland bedroeg op dat moment 8.910 ha.

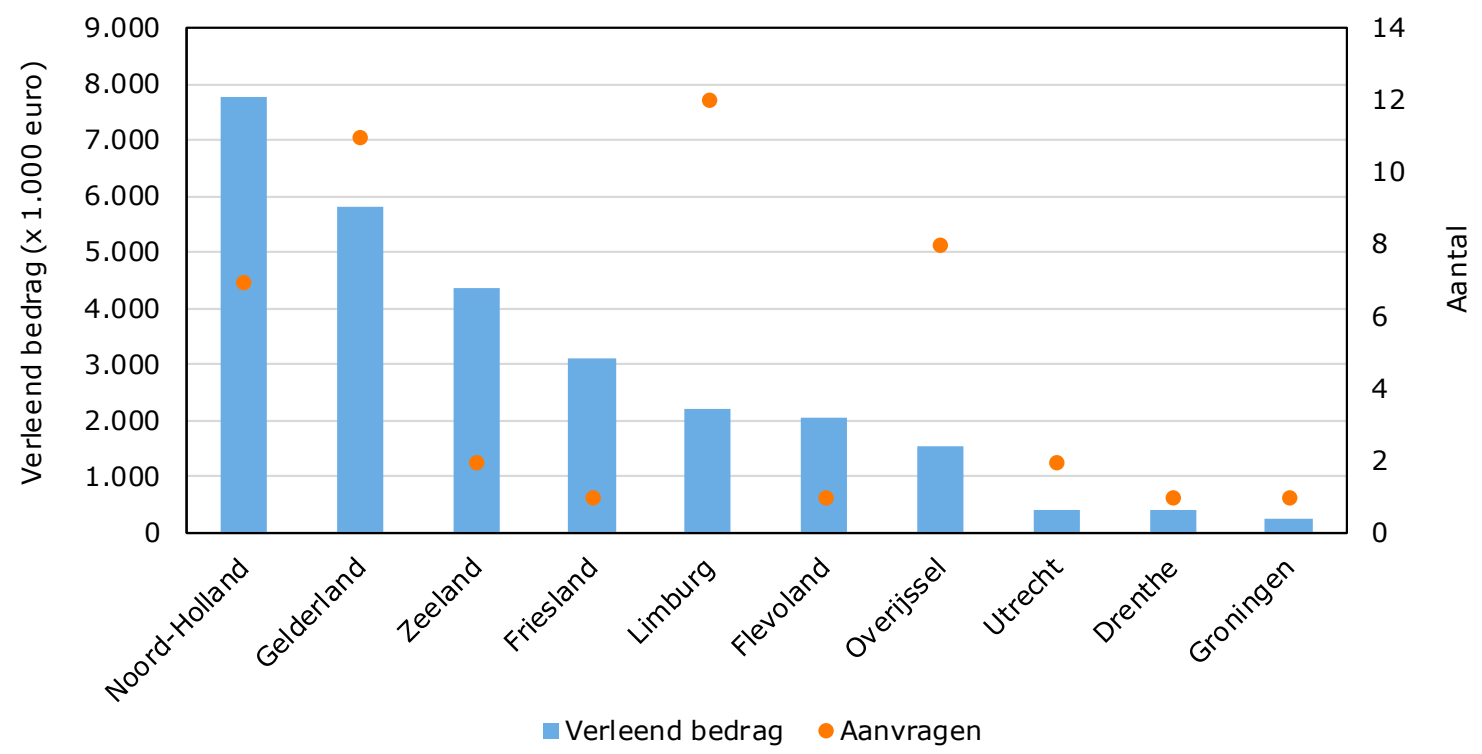

Figuur 5.1 Verleend bedrag ( $x €$ 1.000) maatregel Verbetering verkaveling a), per provincie, 2016 tot en met 2018

a) Inclusief bedrijfsverplaatsingen.

\footnotetext{
${ }^{27}$ Dit is exclusief het bedrag openstellingen Verplaatsingsregeling Glastuinbouw Gelderland.
} 


\subsection{Doeltreffendheid}

Er is onder de geïnterviewden een groot draagvlak voor een positieve beantwoording van bovenstaande evaluatievraag. De maatregel zorgt zeker voor een betere verkavelingsstructuur op de deelnemende agrarische bedrijven. Dit leidt tot lagere kosten op een aantal vlakken als transport en arbeid $^{28}$ Ook biedt de verbetering van de kavelstructuur voor deelnemende agrarische bedrijven tot mogelijkheden tot meer weidegang en daarmee ook mogelijkheden tot een verhoging van verkoopopbrengsten (denk aan weidemelk). Dit alles geeft positieve impulsen aan de inkomens en bevordert daarmee ook de concurrentiekracht en perspectief van bedrijven.

Een goede verkaveling wordt steeds belangrijker, nu elke $\mathrm{m}^{2}$ grond telt. Dit ook in verband met de Pen $\mathrm{N}$ - mestwetgeving. Naast schaalvergroting door bestaande bedrijven speelt ook verduurzaming van bedrijven en daarmee de sector een rol. Gronden zo goed mogelijk ontsloten en dicht bij elkaar (concentratie van kavels) zijn voor een groot aantal aspecten van duurzaamheid van belang: minder $\mathrm{CO}_{2}$-uitstoot (efficiënter werken machines en arbeid), verkeersveiligheid en het integreren van natuur op het bedrijf.

In sommige projecten zijn er volgens de geïnterviewden ook voordelen voor de natuur beherende organisaties: ook zij kunnen door ruilen van gronden en terreinen efficiëntere eenheden krijgen die gemakkelijker en daardoor met minder kosten te beheren zijn.

In zijn opzet is de regeling breed inzetbaar. Primair binnen de regeling staat de agrarische structuurversterking. Vanuit de praktijk (interviews) komt naar voren dat de start van een voorbereidingstraject vooral vanuit de agrarische sector komt, met als inzet (en budget) verbetering van de agrarische structuur. Vaak sluiten andere partijen zich erbij aan: waterschap met waterdoelen en veelal provincie met natuur- en landschapsdoelen. Als alle of meerdere partijen grond inbrengen (mede als ruilgrond) wordt via deze vrijwillige kavelruil in grote mate de (veelal integrale gebieds-) doelen verwezenlijkt. Behalve een versterking van de landbouwstructuur wordt binnen het project bijvoorbeeld ook rekening gehouden met behoud of uitbreiding van natuurgebieden, een goede waterhuishouding, en wegen (verkeersveiligheid). Met inbreng van grond door alle of meerdere partijen is er een duidelijker eigen positie en belang waar in het hele proces rekening mee kan worden gehouden.

Ook kunnen provincies grond inbrengen: zo heeft de provincie Overijssel via het 'Revolving Fund' een provinciale grondvoorziening voor natuurdoelen die als smeerolie ingezet kunnen worden voor projecten met kavelruil, zodat ook natuurdoelen verwezenlijkt kunnen worden.

Bij de regeling is de voorfinanciering van projecten door de aanvragers (stichtingen) soms moeilijk. Een zeer ervaren organisatie als STIVAS vangt dit met betrekking tot projecten in Flevoland (voor projecten in Noord-Holland speelt dit niet) door via Nationaal Groenfonds aanvullende leningen te verkrijgen, omdat ze over een eigen vermogen beschikt wat als garantie dient. Bij andere partijen ligt dit soms veel moeilijker.

Zonder POP3-financiering verloopt volgens de geïnterviewden het rondzetten van kavelruilprojecten veel moeizamer of projecten komen er niet. Ook de maatschappelijke opgaven zullen zonder deze regeling veel sneller blijven liggen. Door meer doelen gemakkelijker mee te nemen en verwezenlijken krijgen gebieden een brede kwaliteitsimpuls.

Tekstbox 5.1

'Zonder de POP3-regeling zullen alleen de meest voordelige ruilingen onder agrariërs plaats vinden: de zogenaamde krenten uit de pap. De minder voordelige ruilingen en de combinatie met andere doelen worden dan niet verwezenlijkt.'

\footnotetext{
${ }^{28}$ Belangrijke voordelen: - koeien gemakkelijker in de wei, minder transportkosten, betere beweiding, beter mineralenmanagement, betere biodiversiteit (www.Kadaster.nl).
} 
De geïnterviewden geven aan dat of een verkaveling wel of niet een meervoudig doel heeft (naast de agrarische structuurverbetering bijvoorbeeld een natuur- of waterdoel) sterk afhankelijk is van lokaal beleid in een regio. Een persoon gaf aan dat vergeleken met POP2 er tegenwoordig minder integrale gebiedsopgaven vooraf uitgewerkt er al liggen, terwijl dat juist erg effectief kan werken.

De kosteneffectiviteit scoort in doorsnee goed. Een geïnterviewde vertelt dat de grootste effectiviteit wordt behaald bij projecten met een omvang van 1.500-2.000 ha, waarin circa 200 ha daadwerkelijk geruild wordt. Bij de meer integrale projecten waarbij resultaatverplichtingen gelden voor bijvoorbeeld natuur en landschap wordt het proces wel moeilijker, maar kan het toch nog goed uitpakken.

Een breed gedragen conclusie is dat provinciaal geld in combinatie met Europees geld veelal een prima combinatie oplevert om de agrarische structuur en andere doelen in het landelijk gebied te versterken. Hoewel bijna alle verkavelingsprojecten nog in een uitvoeringsfase zitten mag op basis van vrijwillige kavelprojecten in zijn algemeenheid worden gesteld dat deze maatregel bijdraagt aan verlaging van de bedrijfskosten en ook een positief effect heeft op de milieueffecten van bedrijfsvoeringen van de betreffende agrarische (grondgebonden) bedrijven.

Tabel 5.1 Bijdrage maatregel Verbetering verkaveling aan algemene evaluatievragen EU (bijvangst, zie ook bijlage 7)

\begin{tabular}{|c|c|}
\hline $\begin{array}{l}\text { Bijdrage aan algemene evaluatievragen } \\
\text { EU }\end{array}$ & Maatregel Verbetering verkaveling \\
\hline $\begin{array}{l}\text { Bevordering concurrentievermogen agrarische } \\
\text { sector }\end{array}$ & $\begin{array}{l}\text { Pas sinds } 2016 \text { zijn nieuwe projecten goedgekeurd onder de maatregel } \\
\text { Verbetering verkaveling. Effecten zijn dus nog niet te meten. De } \\
\text { verwachting is dat goedgekeurde projecten na afronding bij zullen dragen } \\
\text { aan een betere kavelstructuur op de deelnemende agrarische bedrijven, en } \\
\text { daarmee tot een toekomstige verbetering van inkomens (vooral lagere } \\
\text { kosten, deels iets hogere opbrengsten) en bevordert daardoor het } \\
\text { toekomstperspectief van deze bedrijven. De bijdrage aan de } \\
\text { concurrentiekracht van de Nederlandse agrarische sector is positief maar } \\
\text { erg beperkt. }\end{array}$ \\
\hline Bevorderen van innovatie in agrarische sector & Deze maatregel levert geen directe bijdrage aan innovatie. \\
\hline
\end{tabular}

\subsection{Doelmatigheid}

Uit de interviews komt duidelijk naar voren dat er grote verschillen bestaan tussen provincies zowel rond de inzet van POP-middelen (zie paragraaf 5.2) voor verbetering van de verkaveling, als ook rond de procedures. In de interviews is ook veel aandacht besteed aan de doelmatigheid van de maatregel Verbetering verkaveling. Dit wordt hieronder als nuttige bijvangst van deze evaluatie voor zowel beleid als praktijk meegenomen. Daarnaast is het relevante informatie voor de toekomstige eindevaluatie.

\section{Algemeen}

In haar opzet is de regeling breed inzetbaar. De regeling is qua beleid goed opgezet, maar in de uitvoeringspraktijk zijn er ook knelpunten. Provincies hebben een verschillende kijk:

- Sommige provincies laten de regeling meer in eigen beheer uitvoeren (of is er direct contact tussen beleidsmedewerkers en verkavelingscoördinatoren)

- De Noordelijke provincies hebben een directe verbinding met uitvoeringsorganisatie (SNN) 
- De meeste provincies leggen de uitvoering neer bij Stichtingen. Stichtingen zijn beperkter qua mogelijkheden. Ze worden gezien als een particuliere organisatie. Zij moeten nu ook tenderen en moeten zich aanpassen. Men loopt ook nog eens tegen de regelgeving aan. Ook hebben ze meestal te weinig eigen middelen om de zaken goed uit te voeren (denk aan voorfinanciering van projecten, bijvoorbeeld $€$ 50.000). Lenen bij derden of bij het Nationaal Groenfonds brengt extra kosten met zich mee, ook afhankelijk van kredietwaardigheid Stichtingen.

Bij kleine verkavelingen lukt voorfinanciering wel, bij grotere projecten loopt het soms vast.

\section{Procedure}

- Een algemeen gedeeld bezwaar is de lange procedure na aanvraag waarbij soms de wettelijke termijn (22 weken is maximale beoordelingstermijn) voor goedkeuring wordt overschreden. De aanwezige energie bij voorbereiding en indiening aanvraag ebt weg uit het gebied. Er is vanuit de praktijk wel begrip dat bij grotere projecten met meer doelen er meer tijd nodig is voor beoordeling;

- Voor projecten tot en met 2018: 'Hoe eerder je kunt beginnen hoe minder snel je tegen de deadline van 31 december 2021 loopt. Je moet voldoende tijd hebben om het projectplan uit te voeren en de gestelde doelen te kunnen halen.'

- Na vaststelling van de beschikking moet het verkavelingsproject binnen 3 jaar uitgevoerd zijn. Dit wordt als een duidelijke verbetering ervaren ten opzichte van POP1 en POP2: toen waren deze termijnen resp. 1 en 2 jaar.

- Het opstellen en indienen van de aanvraag is duidelijk en goed te doen (mits je ervaring hebt!). Nieuwe stichtingen hebben echter tijd nodig om de procedures te leren (ervaring op te doen). Er zijn na de aanvraag diverse instanties die de aanvraag bekijken en mee beslissen: onder meer adviescommissie, RVO, provincie, provinciebestuur.

- Het is een duidelijke en overzichtelijke regeling, maar met veel administratie. 'Het vergt wel een enorm uithoudingsvermogen om de inhoud goed op papier te krijgen en de uitvoering precies volgens de regels uitgevoerd te krijgen; er zit een hoop administratie en risico aan.'

- Elke provincie stelt (eventueel) eigen voorwaarden op. Daarin zitten soms verschillen: notaris en kadasterkosten worden soms wel en soms niet opgenomen ter vergoeding bij de aanvraag. Proceskosten worden wel voor $100 \%$ vergoed.

- Let op tijdstip van toekenning aanvraag: in het voor boeren drukke voorjaars (groei)seizoen geeft dit complicaties: er is moeilijk tijd vrij te maken voor vergaderingen en verdere opstart.

- De tenderprocedure wordt in de eerste jaren van POP3 niet als positief ervaren. Partijen (zowel indieners, als degene die procedures uitzetten of een beoordeling doen) hebben er weinig tot geen ervaring mee. In meerdere provincies wordt aangegeven dat na aantal jaren ervaring opdoen, en soms met aanpassingen in procedures, het tenderproces in 2018 beter verliep. In een aantal provincies is de lijn tussen de beleidsmedewerkers van de provincie en die van een stichting kavelruil korter en sterker geworden.

- In vergelijking tot POP2 wordt er minder ingediend vanuit integrale gebiedsvisies en opgaven. Bij dergelijke opgaven is veel voorwerk al gedaan, is vooraf al een goed onderbouwd plan welke opgaven er vanuit verschillende doelen zijn. Nu bij een tenderprocedure zie je bij de indiening vrij globale opgaven, mede om de kosten vooraf beperkt te houden. Bij tenderen is de kans op afwijzing immers groter. Pas na goedkering vindt er een nadere detaillering plaats. Globale aanvragen zij ook lastiger te beoordelen.

- Het grotere risico op afwijzing leidt ertoe dat minder partijen aanjager van een project willen zijn. Bij belangenorganisaties in de landbouw speelt dit een rol; De regeling zou praktischer kunnen. Theorie en praktijk sluiten soms moeilijk op elkaar aan. Dit kan het risicoprofiel voor aanvrager verlagen.

- Om risico's aanvrager te verkleinen: werk ook met kwaliteitskenmerken. Als je als organisatie (aanvrager) punten kunt verzamelen (in de loop van de POP-programma's) bij positief afsluiten POP-verkavelingsprojecten neem je die ervaring in punten mee naar een volgende aanvraag. Als die voldoende zijn verzameld dan heb je minder procedures te doorlopen

- In meerdere regio's is er ook bij verplicht tenderen maar 1 aanbieder die inschreef.

- $\mathrm{Er}$ is in de praktijk nogal eens onduidelijkheid over toepassing van juiste tarieven. Opmerking: De officiële EU-tarieven zijn soms zodanig dat je onder de kostprijs moet werken. Sommige Stichtingen, particuliere bureaus of bijvoorbeeld LTO-projecten kunnen het voor deze tarieven niet doen, en haken dan ook soms af. 
Een aantal aanbevelingen vanuit de interviews:

- Streef naar één Nationale Regeling, dit geeft rond de procedure voordelen. Zeker bij de grotere projecten. Het goed formuleren van de geschikte beleidsdoelen is belangrijk: naast agrarische structuur, accenten leggen op natuur, kringlooplandbouw, Kader Richtlijn water, en dergelijke. Het moet duidelijk zijn welke van deze doelen voor financiering in aanmerking komen en welke niet.

- Het uitvoeringsorgaan RVO heeft drie doelen: eenvoudige procedures, voldoende focus, en voorkomen van boetes uit Brussel. RVO kijkt nu vooral naar de rechtmatigheid (voorkomen boetes uit Brussel). Ze zouden meer een faciliterende rol op zich kunnen nemen. Meer meedenken is gewenst.

- De praktijk - een aanvrager - biedt aan ter voorbereiding op een volgend POP-programma aan de voorkant mee te denken, ervaringen te delen, inzicht in uitvoering en administratie te geven.

\subsection{Verplaatsing glastuinbouwbedrijven}

\subsubsection{Beleidstheorie}

\section{Verplaatsingsregeling glastuinbouw Gelderland}

Sinds 2009 is de verplaatsingsregeling glastuinbouw in Gelderland van kracht, waarmee provincie Gelderland (solitaire) glastuinbouwbedrijven financieel ondersteunt bij het verplaatsen naar specifiek aangewezen gebieden met doorgroeimogelijkheden. Dit betreft het verplaatsen van bestaande toekomst vaste of volwaardige bedrijven naar twee intensiveringsgebieden (Bommelerwaard en Lingewaard) en drie regionale clusters voor glastuinbouwontwikkeling (Tuil, Elst en Voorst). Deze regeling is sinds 2014 onderdeel van de POP3-regeling Verkaveling. Het is een tijdelijke regeling uitgaande van een investeringscyclus van 15 jaar (2009-2024). Het doel van de regeling is om volwaardige bedrijven doorgroeimogelijkheden te bieden in de intensiveringsgebieden en daarmee de concurrentiekracht van deze bedrijven en de Gelderse glastuinbouw te versterken.

Vernieuwing van bedrijven biedt ook veel mogelijkheden tot toepassing van duurzame investeringen (modernisering). De regeling heeft als nevendoelstelling om verspreid glas op sprokkellocaties te laten verdwijnen, en dat de bedrijfsvoering op deze locaties ook daadwerkelijk stopt.

\section{Verplaatsingsregeling glastuinbouw Noord-Holland}

Er is $€ 9,3 \mathrm{mln}$. beschikbaar voor de verplaatsingsregeling glastuinbouwbedrijven Noord-Holland: het verplaatsen van bedrijven vanuit het buitengebied naar zogenaamde glasconcentratiegebieden. De clustering heeft als doel het vestigingsklimaat te versterken (verbetering landbouwstructuur, modernisering bedrijven, opruimen oud glas, bijdrage aan energieneutraal op termijn) en heeft als effect een aantrekkelijker landschap en natuur. In Noord-Holland Noord zijn er drie concentratiegebieden: Agriport A7 in de Wieringermeer, Grootslag bij Andijk en Alton in Heerhugowaard.

\subsubsection{Bereik}

Verplaatsingsregeling glastuinbouw Gelderland

In de periode 2009-2017 zijn binnen de Verplaatsingsregeling Glastuinbouw Gelderland 32 aanvragen gehonoreerd (bijlage 4). In de periode dat POP3 van toepassing is (2014-2018), betrof dit 11 bedrijven (met 17 aanvragen) Het goedgekeurde bedrag bedroeg tot en met eind 2018 $€ 4,19 \mathrm{mln}$. $\mathrm{Er}$ is voor $€ 15,42 \mathrm{mln}$. aangevraagd. De laatste openstelling is eind 2018 gesloten, maar goedkeuring vindt in 2019 plaats (met een plafond van $€ 3 \mathrm{mln}$.).

Over de periode $2014-2018$ is niet bekend om hoeveel $\mathrm{m}^{2}$ vernietiging en verplaatsing het gaat. In de studie over 2009-2017 komt naar voren dat de nieuwe bedrijfsoppervlakte iets onder het niveau ligt dan de oppervlakte op gestopte locaties plus oppervlakte op sprokkellocaties (tabel B4.3). Er mag worden aangenomen dat de periode 2014-2018 eenzelfde trend laat zien. 
Geschat wordt dat na 2017 rond de 100 bedrijven met tuinbouw onder glas in de extensiveringsgebieden in Gelderland nog mogelijk in aanmerking kan komen voor de verplaatsingsregeling glastuinbouw (Ruis, 2019). Dit is een substantieel aantal, de regeling loopt volgens planning nog door tot en met 2024. Ook in de intensiveringsgebieden zelf is een substantieel aantal bedrijven (circa 75) dat mogelijk in aanmerking komt voor de verplaatsingsregeling, waarmee de herstructurering in de intensiveringsgebieden verder kan worden gestimuleerd

Verplaatsingsregeling glastuinbouw Noord-Holland

Er zijn zeven subsidieaanvragen ingediend voor een totaal gevraagd subsidiebedrag van $€ 5,1 \mathrm{mln}$. De totale investeringen van deze bedrijfsverplaatsingen zijn geraamd op ruim $€ 70 \mathrm{mln}$. In totaal is in 2018 voor een bedrag van $€ 4.440 .940$ goedgekeurd.

\subsubsection{Doeltreffendheid}

\section{Verplaatsingsregeling glastuinbouw Gelderland}

De regeling levert een waardevolle bijdrage aan de structuurversterking van de glastuinbouw in Gelderland. Daarnaast wordt sterk verspreid glas (sprokkellocaties) verminderd. Meer intensivering leidt tot meer samenwerking en daarmee versterking van het Gelderse tuinbouwcluster. Door vernieuwing van bedrijven door verplaatsing wordt gebruik gemaakt van innovatieve investeringen (gericht op verduurzaming productieproces) met de nieuwste (kostenbesparende) technieken en daarmee ontstaan (beter) op de toekomst voorbereide bedrijven.

In het algemeen hebben de verplaatsende bedrijven relatief jonge ondernemers of zitten in een opvolgingstraject (potentiele opvolgers met terugtredende ouders) en kunnen met de nieuwe bedrijven goed vooruit. De regeling stimuleert dan ook de toetreding (of het niet eruit stappen) van jonge ondernemers en heeft een positief effect op de opvolging. Er mag worden verwacht dat goed ondernemerschap een belangrijk aspect is om een nieuw bedrijf elders te beginnen. De regeling leidt ook tot het op termijn stoppen van bedrijven die niet willen verkassen.

Versterking ondernemerschap, betere ligging, beschikbaarheid van goede grond en gebruik van een goede (betere) kennisinfrastructuur zijn positieve effecten op de concurrentiekracht van het Gelderse tuinbouwcluster.

Bovenstaande zal naar verwachting een positief effect hebben op de (fysieke en daarmee financiële) opbrengsten. Ook mag worden verwacht dat modernisering van bedrijven ook kostenbesparingen opleveren (zoals arbeid), zodat per saldo dit leidt tot een positief effect op de inkomens. Hoe groot dit effect is moeilijk te kwantificeren en bedrijfsafhankelijk. Ondanks $40 \%$ subsidie op in de regeling beschreven kostenposten, zal toch ook een belangrijk deel van de verplaatsing zelf gefinancierd moeten worden. Ook vergroting van het bedrijf ten opzichte van het verlaten bedrijf, valt niet onder de subsidieregeling. Er wordt een normbedrag per $\mathrm{m}^{2}$ vastgesteld op basis van de oppervlakte van het oude bedrijf.

Een groot (economisch) voordeel van de regeling is de tijdsduur van de regeling (15 jaar). Bedrijven kunnen kiezen te verplaatsen op het moment dat bestaande kassen/gebouwen afgeschreven zijn (de afschrijvingsduur is ongeveer 15 jaar) en het tijd is voor een nieuwe investeringscyclus.

Uit nader onderzoek (Ruijs, 2019) kan worden afgeleid dat de verplaatsingsregeling glastuinbouw in Gelderland ook in de komende jaren dat POP3 loopt, een positieve impuls zal geven aan verdere modernisering en herstructurering van de glastuinbouw en de verbetering van de ruimtelijke kwaliteit van gebieden waar solitaire glastuinbouwbedrijven nu nog gevestigd zijn.

Ook zal de verdere concentratie van bedrijven in intensiveringsgebieden leiden tot versterking van de betreffende ketens en daarmee aan de concurrentiekracht.

\section{Verplaatsingsregeling glastuinbouw Noord-Holland}

Er zijn gezien de toekenning in 2018 nog geen concrete effecten meetbaar. In de

concentratiegebieden is naar verwachting na realisatie veel benodigde infrastructuur aanwezig om 
milieuvriendelijk te produceren, denkend aan aansluiting op warmtenetten, geothermie bronnen en een $\mathrm{CO}_{2}$-net. ${ }^{29}$

\subsubsection{Doelmatigheid}

\section{Verplaatsingsregeling glastuinbouw Gelderland}

Wageningen Economic Research heeft nader onderzoek (Ruijs, 2019, concept) verricht naar de volgende toegepaste criteria bij de beoordeling door de provincie Gelderland:

- volwaardigheid bedrijf of volwaardig in gebruik (met aantal subcriteria)

- verplaatsing van het gehele bedrijf (van de solitaire locatie) naar het intensiveringsgebied of regionale glastuinbouwcluster

- behoud van het eigenaarschap: ondernemer is en blijft eigenaar in de nieuwe situatie

- behoud van teelt(richting): op het nieuwe bedrijf wordt dezelfde teelt van producten aangehouden.

Op basis van het onderzoek is geconcludeerd dat van de 32 gehonoreerde aanvragen in de periode 2009-2017 (inclusief intrekkingen) 31 aanvragen hebben voldaan op de gestelde criteria.

Wel valt in de periode 2016-2017 op dat er relatief meer aanvragen zijn, waarvan het (gedeeld) eigendom minder dan drie jaar bij de aanvrager lag. Uiteindelijk (na herbeschikking) bleek dit geen reden voor afwijzing, omdat de aanvraag voldeed aan de andere beoordelingscriteria. Of deze ontwikkeling een trend wordt, valt moeilijk een uitspraak over te doen. De regeling is goed bekend bij de potentiële doelgroep tuinders, vooral ook via de adviseurs.

\subsection{Conclusies en aanbevelingen}

Verbeterde verkaveling

\section{Doeltreffendheid}

- De POP3-maatregel Verbetering verkaveling zal zorgen voor een betere verkavelingsstructuur op de deelnemende agrarische bedrijven. Dit zal leiden tot verbetering van inkomens (vooral lagere kosten, deels iets hogere opbrengsten) en bevordert daardoor ook het perspectief van agrarische bedrijven en daarmee de concurrentiekracht van de Nederlandse agrarische sector.

- Een betere verkaveling in de agrarische sector leidt tot milieuwinsten op een aantal vlakken.

- Bij projecten met meervoudige doelen (ongeveer twee derde van de projecten) worden in sterke mate positieve effecten bereikt (betreft veelal natuur, water en verkeersveiligheid).

- Een verplaatsingsregeling voor agrarische bedrijven wordt maar in 1 provincie specifiek toegepast. Deze regeling levert een substantiële bijdrage aan verduurzaming en versterking concurrentiekracht van deze sector.

- Ongeveer twee derde van de projecten heeft een meervoudig doel. Vooral natuur- en eveneens waterdoelen krijgen lokaal belangrijke impulsen mee.

\section{Bereik en Doelmatigheid}

- Procedure en prioritering beleidsdoelen heeft geleid tot een forse daling van het begrote budget voor verkaveling tussen de start van POP3 en eind 2018.

- Vooral ook verandering in procedures (ten opzichte van POP2) heeft geleid tot een late opstart van de maatregel (nieuwe POP3-projecten pas in 2016). Pa na enkele jaren ervaring (waar zijn we tegenaan gelopen, wat leren ervan en hoe gaan we die leereffecten toepassen) loopt in een aantal provincies de procedure soepel(er).

- Door verandering in procedure zijn de aanvragen vooraf globaler uitgewerkt. Potentiele aanjagers (zoals landbouworganisaties) lopen minder hard voor indiening, dit in verband met groter risico op afwijzing bij tenderen. Een aantal provincies geeft aan aanvragen afkomstig uit goed uitgewerkte integrale gebiedsopgaven (veel bij de vorige POP's) te missen.

- De verruiming van de doorlooptijd naar 3 jaar wordt zeer positief beoordeeld.

$\overline{29}$ https://www. fedecom.nl/nieuws-list/70-miljoen-euro-aan-glastuinbouwinvesteringen-in-de-pijplijn/ 


\section{Aanbevelingen}

- Provincies: deel veel meer de leerervaringen van tenderprocedures met elkaar.

- De praktijk heeft een sterke behoefte aan meer uniformiteit in procedures en openstellingen.

\section{Conclusies Verplaatsingsregeling glastuinbouw in Gelderland}

- De verplaatsingen hebben geleid tot een versterking van de landbouwstructuur. De moderne bedrijven geven in doorsnee een positieve impuls aan kosten en opbrengsten. Dit, en meer concentratie qua ligging bij de ketenpartijen, zal een stimulans met zich meebrengen voor de concurrentiekracht;

- Versterking van de ruimtelijke kwaliteit (minder sprokkellocaties glas);

- In doorsnee een positief effect op bedrijfsopvolging;

- Regeling houdt goed rekening met bedrijfssituatie. Door de lange duur van de regeling (beoogde termijn van 15 jaar) kan verplaatsing beter aansluiten bij het afschrijvingsritme van de kassen (verplaatsen als kassen grotendeels zijn afgeschreven). 


\section{Literatuur en websites}

Berkhout, P., M. Van Asseldonk, R.W. van der Meer, H.A.B. van der Meulen en H.J. Silvis, 2016. Evaluatie Regeling brede weersverzekering. Wageningen, Wageningen Economic Research, Rapport 2016-070.

Bureau Bartels (2016). Evaluatie eerste openstelling Regeling jonge landbouwers onder POP3. Amersfoort, 7 november 2016.

NAJK (2016). Evaluatie JOLA door NAJK. September 2016.

Ruijs, M., Beoordeling verplaatsingsregeling glastuinbouw Gelderland, Wageningen Economic Research (nog te publiceren)

\section{Websites:}

www.agrimatie.nl

www.fedecom.nl

Websites vele provincies

https://regiebureau-pop.eu/

https://nieuweoogst.nh

https://subsidiefocus.nl

www.rvo.nl

https://www.rijksoverheid.nl/ministeries/ministerie-van-landbouw-natuur-en-voedselkwaliteit 


\section{Bijlage 1 Maatregel Kwaliteitsregeling Kalveren}

\section{Geïnterviewde personen}

- Wim Thus, LTO Noord vakgroep kalverhouderij

- Henk Bekman, SBK

- Pascalle de Ruyter, ministerie van LNV

Geraadpleegd: Willy Baltussen, Wageningen Economic Research

\section{Structuur vleeskalverhouderij in 2016}

\begin{tabular}{|c|c|c|c|c|c|c|c|c|}
\hline Gespecialiseerde bedrijven & $\begin{array}{r}<100 \\
\text { kalveren }\end{array}$ & $\begin{array}{l}100-300 \\
\text { Kalveren }\end{array}$ & $\begin{array}{l}\text { 300-600 } \\
\text { kalveren }\end{array}$ & $\begin{array}{r}600- \\
1.000\end{array}$ & $\begin{array}{r}1.000- \\
1.500\end{array}$ & $\begin{array}{r}1.500- \\
2.500\end{array}$ & $\begin{array}{r}>2.500 \\
\text { kalveren }\end{array}$ & Totaal \\
\hline & & & & kalveren & kalveren & kalveren & & \\
\hline \multicolumn{9}{|l|}{ Rose } \\
\hline aantal bedrijven (rose) & 100 & 189 & 143 & 109 & 42 & 21 & 5 & 609 \\
\hline w.v. met blank & 0 & 0 & 1 & 1 & 3 & 3 & 0 & 8 \\
\hline totaal vleeskalveren & $6 ., 326$ & 35.126 & 63.976 & 84.661 & 51.416 & 40.242 & 15.211 & 296.958 \\
\hline w.v. blank & 0 & 0 & 182 & 371 & 1.422 & 2.128 & 0 & 4.103 \\
\hline gemiddeld per bedrijf & 63 & 186 & 447 & 777 & 1.224 & 1.916 & 3.042 & 488 \\
\hline \multicolumn{9}{|l|}{ Blank } \\
\hline aantal bedrijven (blankvlees) & 9 & 70 & 154 & 195 & 160 & 44 & 16 & 648 \\
\hline w.v. met rose & 0 & 3 & 8 & 8 & 15 & 5 & 8 & 47 \\
\hline totaal vleeskalveren & 525 & 14.930 & 71.640 & 154.076 & 192.603 & 79.854 & 55.217 & 568.845 \\
\hline w.v. rose & 0 & 92 & 359 & 874 & 2.417 & 2.943 & 3.405 & 10.090 \\
\hline gemiddeld per bedrijf & 58 & 213 & 465 & 790 & 1.204 & 1.815 & 3.451 & 878 \\
\hline \multicolumn{9}{|l|}{ blank en rose } \\
\hline totaal bedrijven & 109 & 259 & 297 & 304 & 202 & 65 & 21 & 1.257 \\
\hline totaal vleeskalveren & 6,851 & 50.056 & 135.616 & 238.737 & 244.019 & 120.096 & 70.428 & 865.803 \\
\hline gemiddeld per bedrijf & 63 & 193 & 457 & 785 & 1.208 & 1.848 & 3.354 & 689 \\
\hline \multicolumn{9}{|l|}{ NIET GESPECIALISEERD } \\
\hline \multicolumn{9}{|l|}{ Rose: geen bedrijf met ook blank } \\
\hline aantal bedrijven (rose) & 192 & 110 & 43 & 10 & 4 & 1 & 0 & 360 \\
\hline totaal vleeskalveren & 6.373 & 20.221 & 18.346 & 7.369 & 5.159 & 1.804 & 0 & 59.272 \\
\hline gemiddeld per bedrijf & 33 & 184 & 427 & 737 & 1.290 & 1.804 & & 165 \\
\hline \multicolumn{9}{|l|}{ Blank } \\
\hline aantal bedrijven (blankvlees) & 19 & 16 & 21 & 13 & 3 & 1 & 1 & 74 \\
\hline w.v. met rose & 2 & 0 & 1 & 0 & 0 & 0 & 1 & 4 \\
\hline totaal vleeskalveren & 448 & 3.095 & 8.704 & 10.238 & 3.692 & 2.223 & 2.637 & 31.037 \\
\hline w.v. rose & 16 & 0 & 55 & 0 & 0 & 0 & 300 & 371 \\
\hline gemiddeld per bedrijf & 24 & 193 & 414 & 788 & 1.231 & 2.223 & 2.637 & 419 \\
\hline \multicolumn{9}{|l|}{ blank en rose } \\
\hline totaal bedrijven & 211 & 126 & 64 & 23 & 7 & 2 & 1 & 434 \\
\hline totaal vleeskalveren & 6.821 & 23.316 & 27.050 & 17.607 & 8.851 & 4.027 & 2.637 & 90.309 \\
\hline gemiddeld per bedrijf & 32 & 185 & 423 & 766 & 1.264 & 2.014 & 2.637 & 208 \\
\hline \multicolumn{9}{|c|}{$\begin{array}{l}\text { Alle bedrijven met vlees- kalveren, } \\
\text { totaal dieren }\end{array}$} \\
\hline Bedrijven & 320 & 385 & 361 & 327 & 209 & 67 & 22 & 1.691 \\
\hline Vleeskalveren & 13.672 & 73.372 & 162.666 & 256.344 & 252.870 & 124.123 & 73.065 & 956.112 \\
\hline Bedrijven (\%) & 34 & 67 & 82 & 93 & 97 & 97 & 95 & 74 \\
\hline Vleeskalveren (\%) & 50 & 68 & 83 & 93 & 96 & 97 & 96 & 91 \\
\hline
\end{tabular}

Bron: Landbouwtelling (RVO). 


\section{Bijlage 2 Maatregel Productieve fysieke investeringen}

\section{Geïnterviewde personen}

- Geert Bruns (Flynth Accountants)

- Hans Jacobs en Judith Maas, Subsidiefocus (onderdeel van ABAB accountants)

- Rene Veldman, Rabobank Nederland

- Sietze Douma, NAJK

- AJK Noord-Holland

- Herman Bouman (POP3-coördinator provincie Groningen)

- Mart Mensink (POP3-coördinator provincie Gelderland)

- Johan Wandel (beleidsmedewerker provincie Zeeland)

- Stephan Melis (POP3-coördinator provincie Noord-Holland).

Geraadpleegde personen:

- Dirk Jan Immenga (POP3-coördinator provincie Drenthe: fysieke regeling Veenkoloniën)

- RVO Nederland (fysieke investeringen Veenkoloniën)

- Wim Thus LTO Noord (fysieke regeling vleeskalveren)

- Amber van Deursen, RVO Nederland (fysieke investeringen vleeskalveren)

\section{Enquêtevragen}

Beste gebruiker van de Regeling Fysieke investeringen voor innovatie en modernisering, Welkom bij deze enquête over de meerwaarde van de Regeling Fysieke investeringen voor innovatie en modernisering. Deze regeling maakt deel uit van het Plattelandsontwikkelingsprogramma 20142020 en is bedoeld om landbouwers te ondersteunen bij investeringen die economisch rendement combineren met maatschappelijke doelen. Deze regeling is ook bedoeld als financiële steun voor de toepassing van innovatieve technieken, processen of producten.

Het ministerie van LNV en het Regiebureau POP willen graag van u weten in hoeverre de ontvangen subsidie vanuit deze regeling $u$ als landbouwer heeft geholpen om de door u gewenste investeringen in uw bedrijf te kunnen doen. Uw input is zeer belangrijk en helpt het ministerie van LNV en het Regie-bureau POP om hun Plattelandsontwikkelingsprogramma en de subsidieregeling Fysieke investeringen voor innovatie en modernisering verder te verbeteren.

Het invullen van de enquête duurt ongeveer 5 minuten. Vanzelfsprekend worden uw gegevens anoniem verwerkt.

Alvast hartelijk dank voor uw bijdrage.

\section{BLOK A: ALGEMENE VRAGEN}

1. In welke agrarische sector bent $u$ werkzaam (de tak met de meeste omzet)?
- Akkerbouw
- Glastuinbouw
- Tuinbouw in de vollegrond
- Melkveehouderij
- Intensieve veehouderij
○ Overig

2. In welke provincie bevindt zich de hoofdvestiging van uw bedrijf?
- Groningen
- Friesland
- Drenthe
- Overijssel
- Gelderland
- Flevoland 

- Noord-Holland
- Zuid-Holland
- Utrecht
- Zeeland
- Noord-Brabant
- Limburg

3. Wat is uw geboortedatum (van de subsidie-aanvrager)? graag invullen als dd-mm-jjjj, bijvoorbeeld 08-03-1970

4. Hoe heeft u de subsidieaanvraag voor de Regeling Fysieke investeringen voor innovatie en modernisering ingediend?

- Door middel van een keuze op een investeringslijst

- Via een open tender/inschrijving met een projectvoorstel voor een investering

o Anders, namelijk ...

\section{BLOK B: INVESTERINGEN}

5. Voor welke type investeringen heeft u subsidie ontvangen uit de regeling Fysieke investeringen voor innovatie en modernisering?

- Behoud en versterking van biodiversiteit en/of omgevingskwaliteit

- Biologische landbouw

- Bodembeheer

- Duurzame stallen

- Emissiearme spuittechnieken

- Maatregelen leidend tot een geringer grondstoffengebruik en/of een gesloten kringloop

- Nieuwe producten/diensten met meerwaarde

- Precisielandbouw

- Waterbeheervoorzieningen

- Overig, namelijk ...

6. Sluit de investeringslijst en/of de open inschrijving via een projectvoorstel voor een investering aan bij uw persoonlijke investeringsbehoefte?

o Zeer goed o Goed o Neutraal o Slecht o Zeer slecht o Weet niet

7. Hoe belangrijk is de investering, waarvoor u subsidie is toegekend vanuit de regeling Fysieke investeringen voor innovatie en modernisering, voor uw bedrijf?

o Zeer belangrijk o Belangrijk o Neutraal o Onbelangrijk o Zeer onbelangrijk o Weet niet

Om het belang van de subsidie vanuit de regeling Fysieke investeringen voor innovatie en modernisering voor $u$ persoonlijk goed in te schatten volgt nu een aantal stellingen:

8. Met de subsidie konden we onderdelen van het investeringsproject doorzetten o Zeer eens o Eens o Neutraal o Oneens o Zeer oneens o Weet niet

9. Met de subsidie konden we eerder starten met het investeringsproject o Zeer eens o Eens o Neutraal o Oneens o Zeer oneens o Weet niet

10. Met de subsidie konden we een hogere kwaliteit van het investeringsproject realiseren o Zeer eens o Eens o Neutraal o Oneens o Zeer oneens o Weet niet

11. Met de subsidie konden we het investeringsproject grootschaliger oppakken o Zeer eens o Eens o Neutraal o Oneens o Zeer oneens o Weet niet

12. Met de subsidie konden we de realisatie van het investeringsproject versnellen in de tijd o Zeer eens o Eens o Neutraal o Oneens o Zeer oneens o Weet niet 
13. De subsidie had geen meerwaarde; zonder subsidie zouden we alles hetzelfde hebben gedaan o Zeer eens o Eens o Neutraal o Oneens o Zeer oneens o Weet niet

\section{BLOK C: EFFECTEN VAN DE GESUBSIDIEERDE INVESTERINGEN}

Hieronder een aantal vragen om de effecten van de gesubsidieerde investeringen voor de prestaties en continuïteit van uw bedrijf goed in te schatten. Graag uw score van deze effecten op de volgende aspecten:

14. Verhoging van de omzet
o Zeer groot o Groot
o Redelijk
o Gering o Geen o Enigszins negatief o Negatief

15. Verlaging van de productiekosten

o Zeer groot o Groot o Redelijk o Gering o Geen o Enigszins negatief o Negatief

16. Modernisering / innoveren van het bedrijf

o Zeer groot o Groot o Redelijk o Gering o Geen o Enigszins negatief o Negatief

17. Verbetering van de duurzaamheid van het bedrijf

o Zeer groot o Groot o Redelijk o Gering o Geen o Enigszins negatief o Negatief

\section{AFSLUITING}

18. Welk belang hecht $u$ aan voortzetting van de Regeling Fysieke investeringen voor innovatie en modernisering binnen POP3?

o Zeer groot o Groot o Redelijk o Gering o Geen o Weet niet

19. Hoe beoordeelt $u$ het uitvoeringsproces van de regeling via de provincie en de RVO? o Zeer goed o Goed o Voldoende o Matig o Slecht o Zeer slecht o Weet niet

Dit waren alle vragen. Heeft u nog opmerkingen naar aanleiding van deze enquête? Dan kunt u die hieronder kwijt.

Hartelijk dank voor het invullen van de enquête!

\section{Resultaten enquête (aanvullend op hoofdstuk 3)}

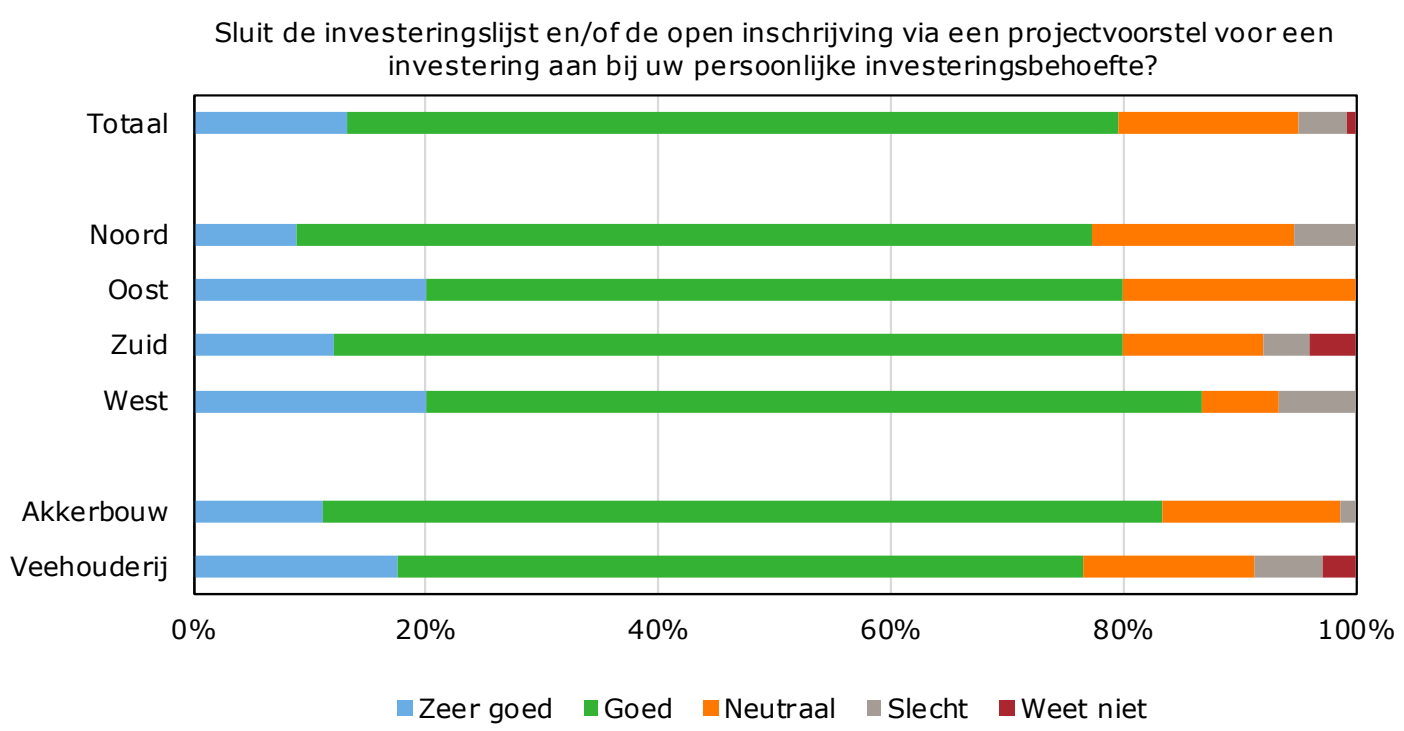

Figuur B2.1 Enquête: Aansluiting regeling bij persoonlijke investeringsbehoefte 


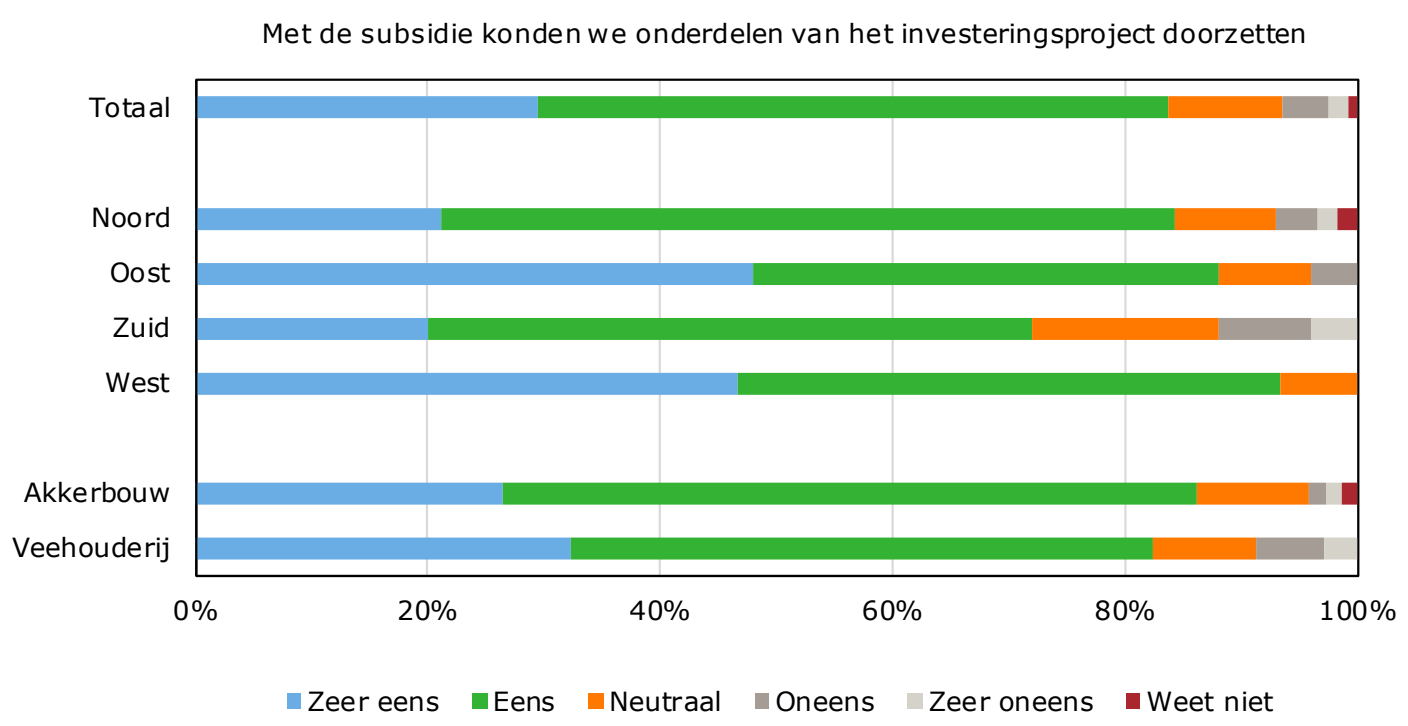

Figuur B2.2 Enquête: Belang voor innovatie en modernisering: onderdelen investering doorzetten

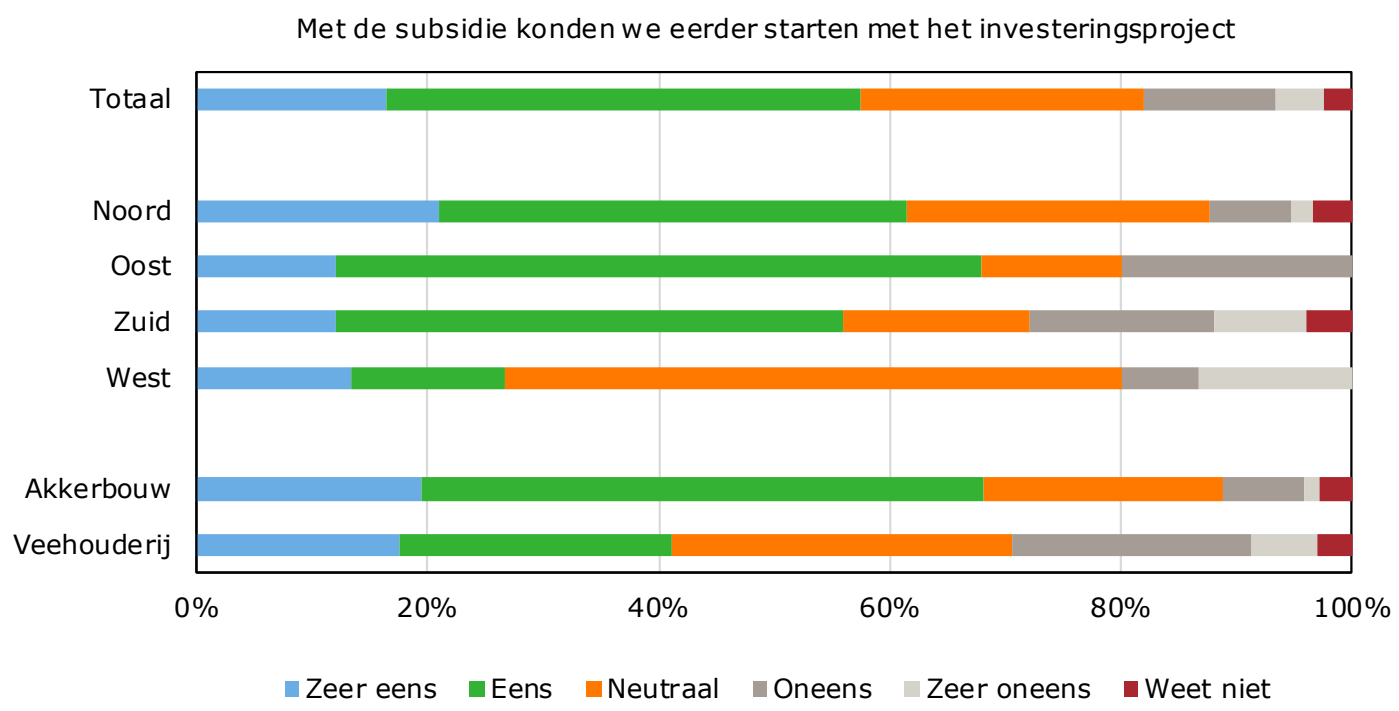

Figuur B2.3 Enquête: Eerder starten met investeringsproject

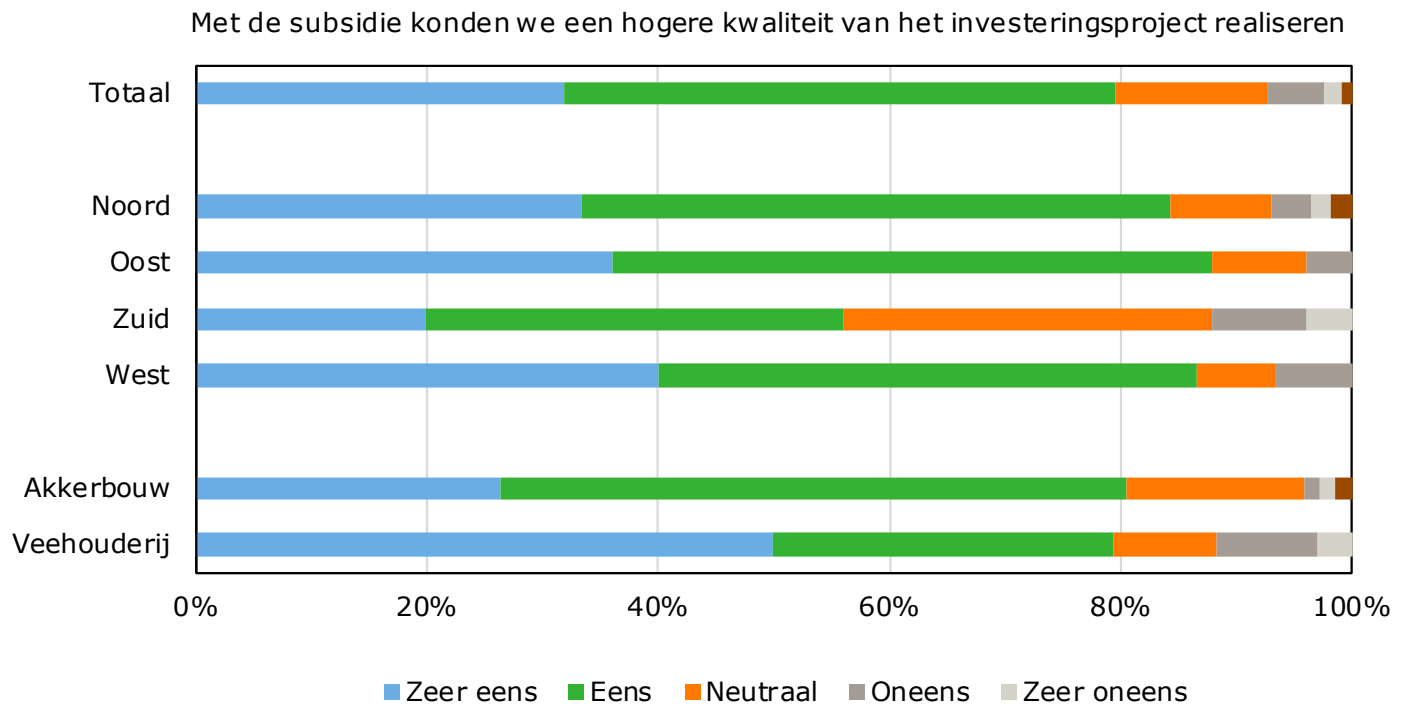

Figuur B2.4 Enquête: hogere kwaliteit van het investeringsproject 
Met de subsidie konden we het investeringsproject grootschaliger oppakken

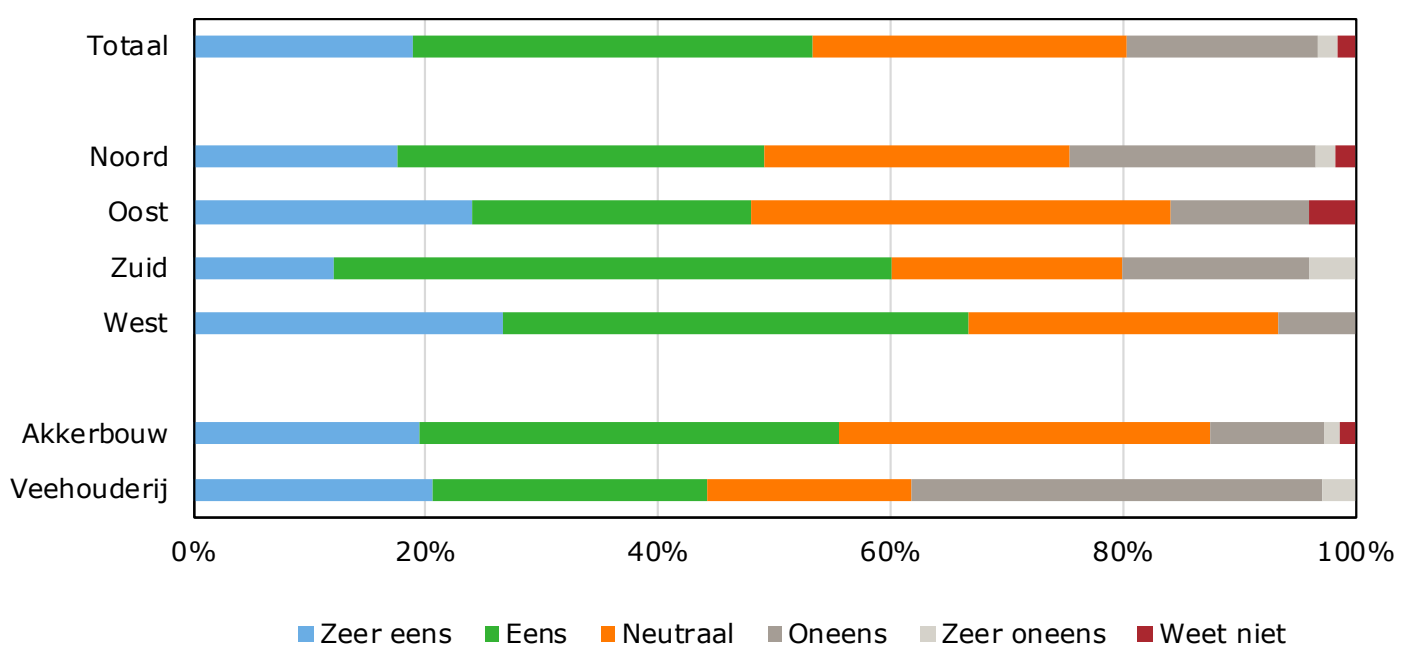

Figuur B2.5 Enquête: Investeringsproject grootschaliger oppakken

Met de subsidie konden we de realisatie van het investeringsproject versnellen in de tijd

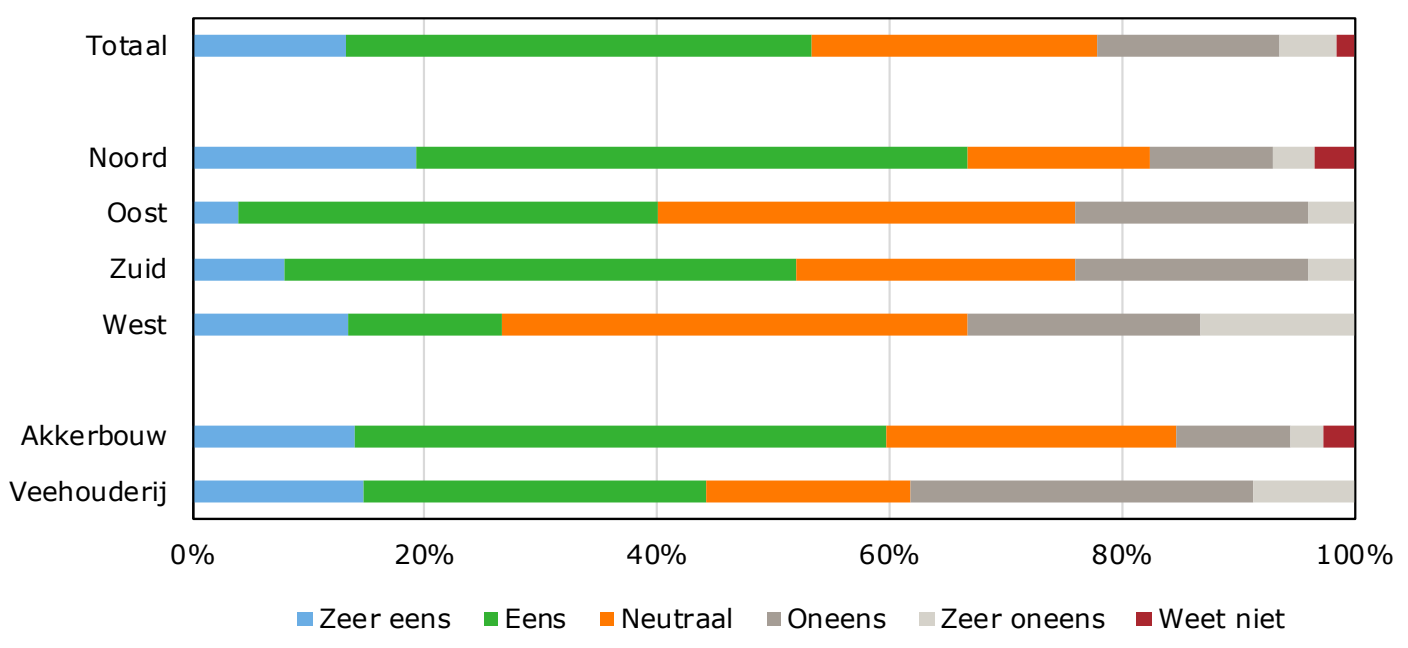

Figuur B2.6 Enquête: Investeringsproject versnellen

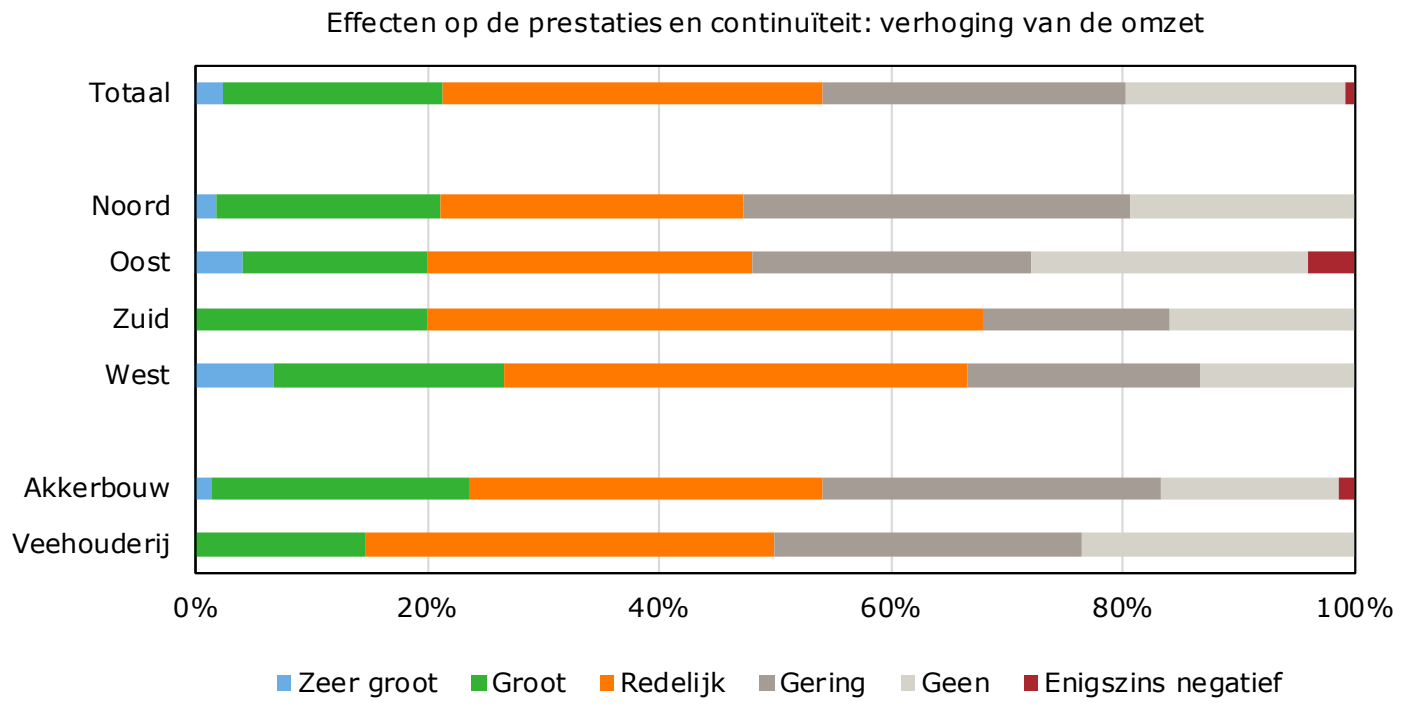

Figuur B2.7 Enquête: Effect van regeling op verhoging van de omzet 
Effecten op de prestaties en continuïteit: verlaging van de productiekosten

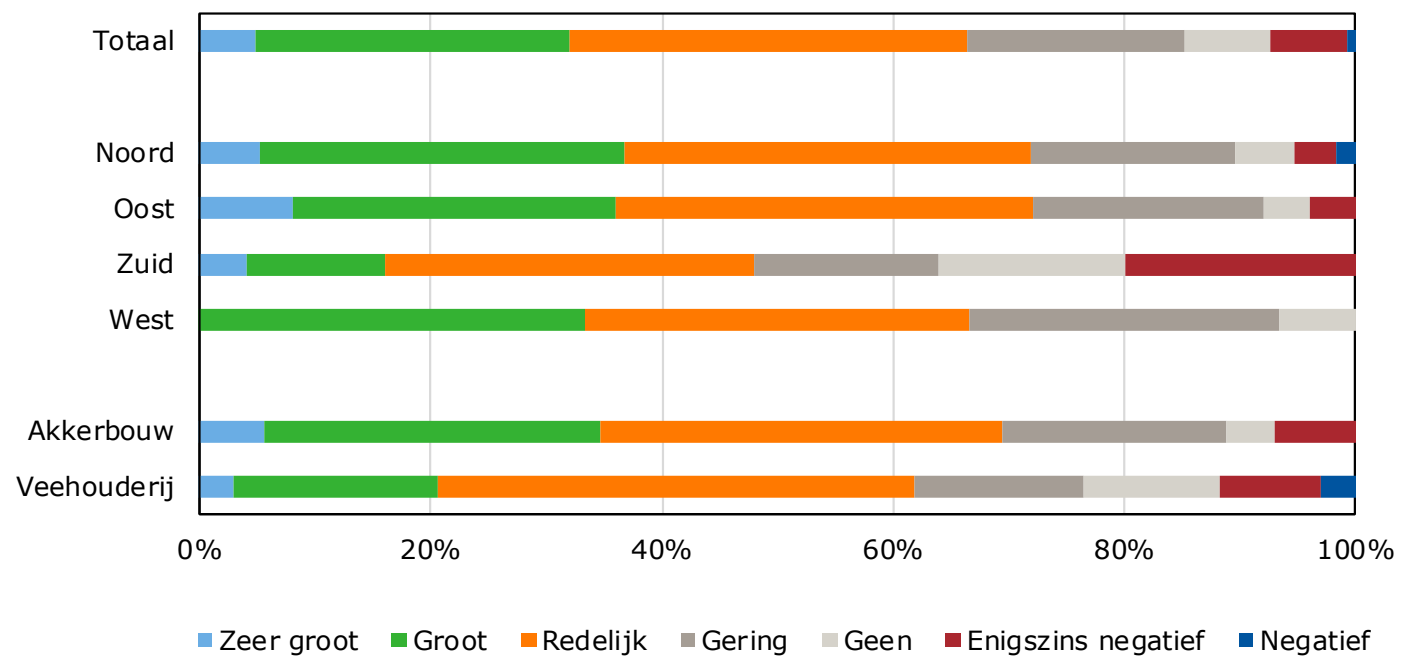

Figuur B2.8 Enquête: Effect van regeling op verlaging productiekosten

Effecten op de prestaties en continuïteit: modernisering / innoveren van het bedrijf

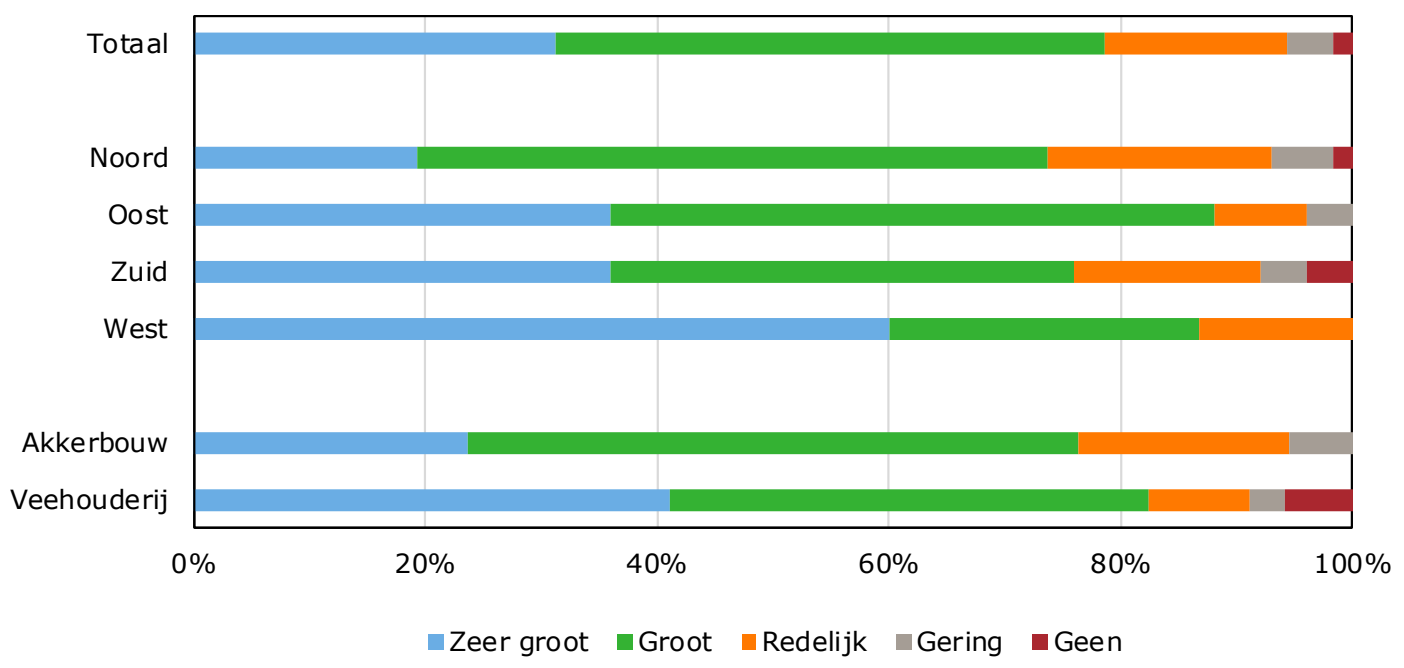

Figuur B2.9 Enquête: Effect van regeling op modernisering/ innovatie

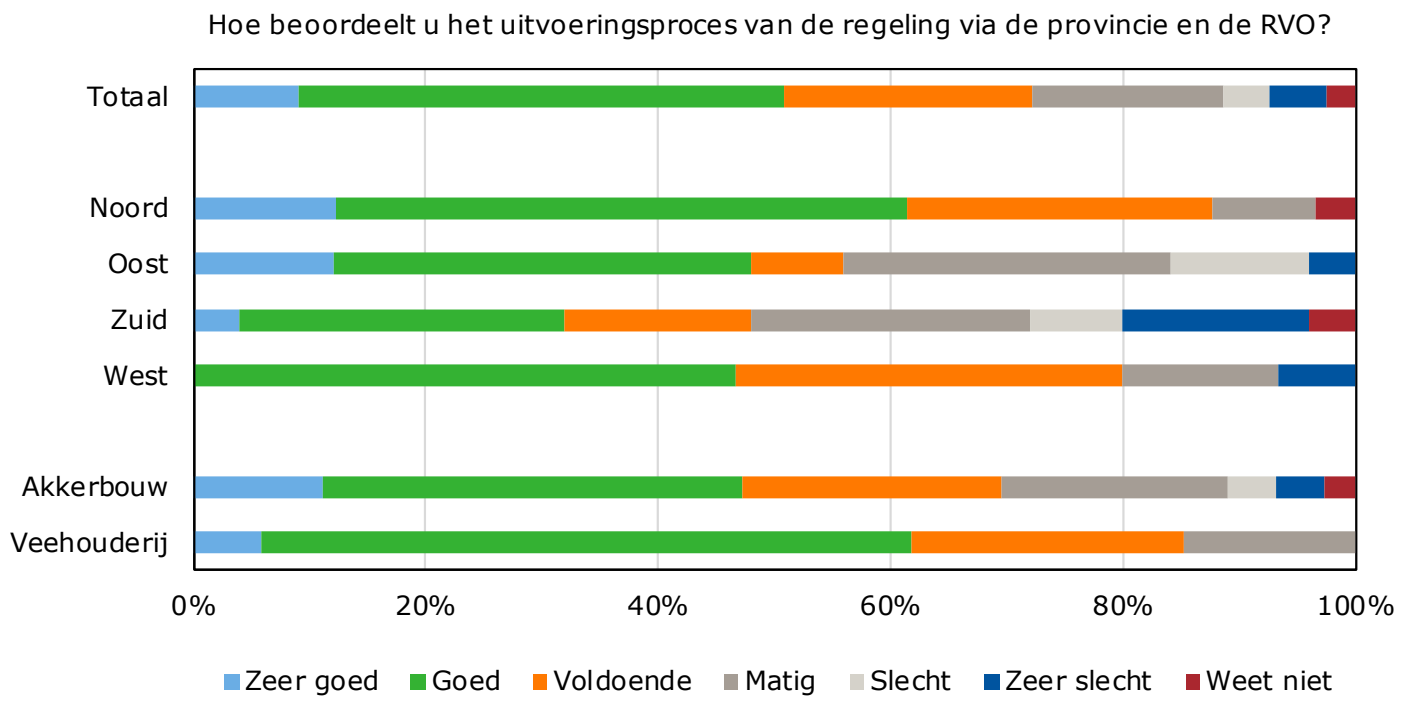

Figuur B2.10 Enquête: Beoordeling uitvoeringsproces via provincie en RVO 
Type investeringen akkerbouw

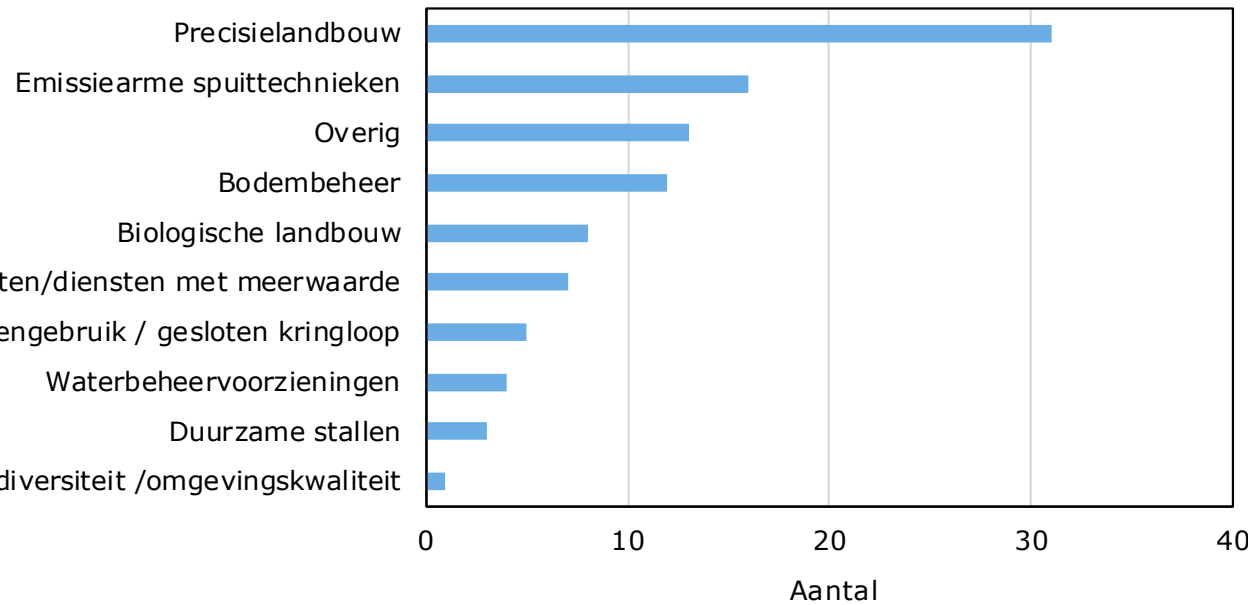

Figuur B2.11 Type investeringen in de akkerbouw, op basis van aantal goedkeuringen onder maatregel Productieve fysieke investeringen

Type investeringen veehouderij

\section{Duurzame stallen}

Geringer grondstoffengebruik / gesloten kringloop

Precisielandbouw

Biologische landbouw

Overig

Biodiversiteit /omgevingskwal iteit

Bodembeheer

Nieuwe producten/diensten met meerwaarde

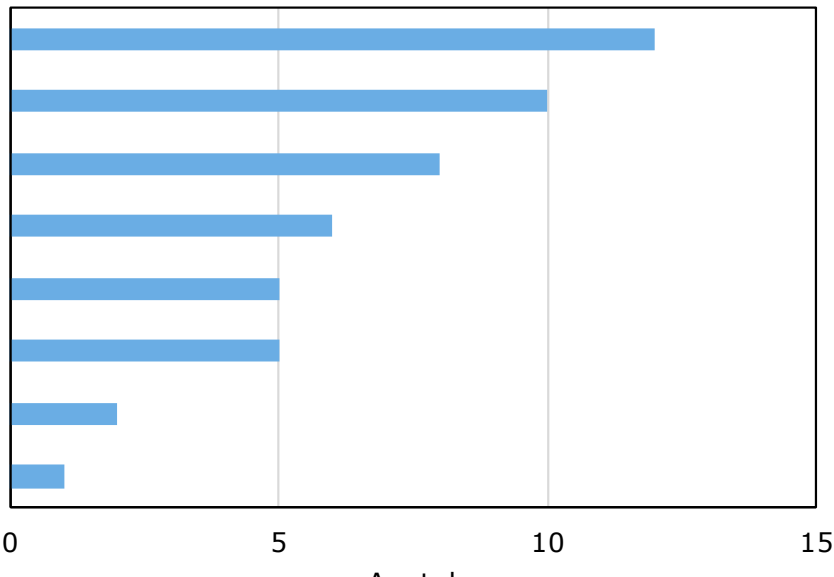

Aantal

Figuur B2.12 Type investeringen in de veehouderij, op basis van aantal goedkeuringen onder maatregel Productieve fysieke investeringen 


\section{Bijlage 3 Maatregel Jonge landbouwers}

\section{Geïnterviewde personen}

- Geert Bruns (Flynth Accountants)

- Hans Jacobs en Judith Maas, Subsidiefocus (onderdeel van ABAB accountants)

- Rene Veldman, Rabobank Nederland

- Sietze Douma, NAJK

- Herman Bouman (POP3-coördinator provincie Groningen)

- Mart Mensink (POP3-coördinator provincie Gelderland)

- Johan Wandel (beleidsmedewerker provincie Zeeland)

- Agrarisch Jongeren Kontakt (AJK) Noord-Holland

\section{Resultaten JoLa naar provincie}

Tabel B3.1 Verleend bedrag Regeling Jonge Landbouwers naar provincie ( $x € 1.000$ ), 2016 tot en met 2018

\begin{tabular}{lrrrr} 
Provincie & 2016 & 2017 & 2018 & Totaal \\
Noord-Brabant & 756 & 578 & 1.577 & 2.911 \\
\hline Overijssel & 726 & 499 & 1.363 & 2.587 \\
\hline Gelderland & 652 & 425 & 1.319 & 2.396 \\
\hline Groningen & 782 & 420 & 959 & 2.161 \\
\hline Friesland & 646 & 363 & 1.022 & 2.030 \\
\hline Drenthe & 594 & 400 & 677 & 1.671 \\
\hline Noord-Holland & 450 & 348 & 806 & 1.604 \\
\hline Zuid-Holland & 660 & 304 & 616 & 1.579 \\
\hline Flevoland & 607 & 353 & 348 & 1.308 \\
\hline Zeeland & 395 & 232 & 452 & 1.078 \\
\hline Utrecht & 488 & 131 & 354 & 972 \\
\hline Limburg & 251 & 226 & 457 & 933 \\
\hline Totaal & 7.007 & 4.277 & 9.949 & 21.232 \\
\hline
\end{tabular}

Bron: RVO, bewerking Wageningen Economic Research.

Tabel B3.2 Verleende bedragen ( $x \in 1$ 1.000) Regeling Jonge Landbouwers naar provincie en belangrijkste investeringscategorieën (2016 tot en met 2018)

\begin{tabular}{|c|c|c|c|c|c|c|}
\hline & Emissiearme vloeren & Grondbewerking & Precisie-bemesting & Zonnepanelen & Overig & Totaal \\
\hline Noord-Brabant & 338 & 199 & 474 & 1.377 & 522 & 2.911 \\
\hline Overijssel & 202 & 31 & 140 & 1.412 & 801 & 2.587 \\
\hline Groningen & 118 & 185 & 273 & 510 & 1.074 & 2.161 \\
\hline Friesland & 229 & 40 & 111 & 1.060 & 590 & 2.030 \\
\hline Noord-Holland & 175 & 70 & 258 & 796 & 305 & 1.604 \\
\hline Zuid-Holland & 91 & 40 & 241 & 935 & 274 & 1.579 \\
\hline Flevoland & 33 & 127 & 385 & 561 & 202 & 1.308 \\
\hline Zeeland & 20 & 180 & 356 & 245 & 278 & 1.078 \\
\hline
\end{tabular}

Bron: RVO, bewerking Wageningen Economic Research. 


\section{Enquêtevragen}

Beste gebruiker van de Regeling Jonge Landbouwers,

Welkom bij deze enquête over de meerwaarde van Regeling Jonge Landbouwers (JoLa). Deze regeling maakt deel uit van het Plattelandsontwikkelingsprogramma 2014-2020 en is bedoeld om jonge landbouwers financieel tegemoet te komen bij de gewenste innovatie en duurzame modernisering van hun agrarische onderneming en zodoende de bedrijfsovername te ondersteunen.

Het ministerie van LNV en het Regiebureau POP willen graag van u weten in hoeverre de JoLa-subsidie $\mathrm{u}$ als jonge landbouwer heeft geholpen om de door $\mathrm{u}$ gewenste investeringen in uw bedrijf te kunnen doen. Uw input is zeer belangrijk en helpt het ministerie van LNV en het Regiebureau POP om hun Plattelands-ontwikkelingsprogramma en de JoLa-subsidieregeling verder te verbeteren.

Het invullen van de enquête duurt ongeveer 5 minuten. Vanzelfsprekend worden uw gegevens anoniem verwerkt.

Alvast hartelijk dank voor uw bijdrage.

\section{BLOK A: ALGEMENE VRAGEN}

1. In welke agrarische sector bent u werkzaam (de tak met de meeste omzet)?
- Akkerbouw
- Glastuinbouw
- Tuinbouw in de vollegrond
- Melkveehouderij
- Intensieve veehouderij
○ Overig

2. In welke provincie bevindt zich de hoofdvestiging van uw bedrijf?
- Groningen
- Friesland
- Drenthe
- Overijssel
- Gelderland
- Flevoland
- Noord-Holland
- Zuid-Holland
- Utrecht
- Zeeland
- Noord-Brabant
- Limburg

3. Wat is uw geboortedatum (van de subsidie-aanvrager)? dd-mm-jjjj

\section{BLOK B: INVESTERINGEN}

4. Voor welke investeringen van de investeringslijst van de JoLa-regeling heeft u subsidie ontvangen (u kon voor maximaal 3 investeringen subsidie aanvragen)?
- Automatisch ruwvoermengsysteem
- Elektrische voertuigen
- Emissiearme vloer in de melkveehouderij
- Fijnstofreductie in pluimveestallen
- GPS-systeem voor koeien (in verband met weidegang)
- Koematras
- Luchtwassysteem in de veehouderij
- Machine voor niet-kerende grondbewerking
- Mestscheidingsinstallatie
- Mestvergister
- Pad cooling in stallen 

- Precisiebemesting
- Spuitmachine met restvloeistofreductie
- Varkensvriendelijke vloer
- Warmtekrachtinstallatie
- Warmtewisselaar
- Waterbeheervoorziening
- Windturbine
- Zaaimachine (in combinatie met spitten)
- Zonnepanelen

5. Sluit de investeringslijst van de JoLa-regeling aan bij uw persoonlijke investeringsbehoefte? o Zeer goed o Goed o Neutraal o Slecht o Zeer slecht o Weet niet

6. Hoe belangrijk is de investering, waarvoor u subsidie is toegekend vanuit de JoLa-regeling, voor uw bedrijf?

o Zeer belangrijk o Belangrijk o Neutraal o Onbelangrijk o Zeer onbelangrijk o Weet niet

Om het belang van de subsidie vanuit de JoLa-regeling voor u persoonlijk goed in te schatten volgt nu een aantal stellingen:

7. Met de subsidie konden we onderdelen van het investeringsproject doorzetten o Zeer eens o Eens o Neutraal o Oneens o Zeer oneens o Weet niet

8. Met de subsidie konden we eerder starten met het investeringsproject o Zeer eens o Eens o Neutraal o Oneens o Zeer oneens o Weet niet

9. Met de subsidie konden we een hogere kwaliteit van het investeringsproject realiseren o Zeer eens o Eens o Neutraal o Oneens o Zeer oneens o Weet niet

10. Met de subsidie konden we het investeringsproject grootschaliger oppakken o Zeer eens o Eens o Neutraal o Oneens o Zeer oneens o Weet niet

11. Met de subsidie konden we de realisatie van het investeringsproject versnellen in de tijd o Zeer eens o Eens o Neutraal o Oneens o Zeer oneens o Weet niet

12. De subsidie had geen meerwaarde; zonder subsidie zouden we alles hetzelfde hebben gedaan o Zeer eens o Eens o Neutraal o Oneens o Zeer oneens o Weet niet

\section{BLOK C: EFFECTEN VAN DE GESUBSIDIEERDE INVESTERINGEN}

Hieronder een aantal vragen om de effecten van de gesubsidieerde investeringen voor de prestaties en continuïteit van uw bedrijf goed in te schatten. Graag uw score van deze effecten op de volgende aspecten:

13. Verhoging van de omzet

o Zeer groot o Groot o Redelijk o Gering o Geen o Enigszins negatief o Negatief

14. Verlaging van de productiekosten

o Zeer groot o Groot o Redelijk o Gering o Geen o Enigszins negatief o Negatief

15. Modernisering van het bedrijf

o Zeer groot o Groot o Redelijk o Gering o Geen o Enigszins negatief o Negatief

16. Verbetering van de duurzaamheid van het bedrijf

o Zeer groot o Groot o Redelijk o Gering o Geen o Enigszins negatief o Negatief 
17. Uw besluit om het bedrijf te starten of over te nemen

o Zeer groot o Groot o Redelijk o Gering o Geen o Enigszins negatief o Negatief

\section{AFSLUITING}

18. Welk belang hecht $u$ aan voortzetting van de Regeling Jonge Landbouwers voor hun toekomst? o Zeer groot o Groot o Redelijk o Gering o Geen o Weet niet

Dit waren alle vragen. Heeft u nog opmerkingen naar aanleiding van deze enquête? Dan kunt u die hieronder kwijt.

Hartelijk dank voor het invullen van de enquête!

\section{Resultaten enquête JoLa (aanvullend op hoofdstuk 4)}

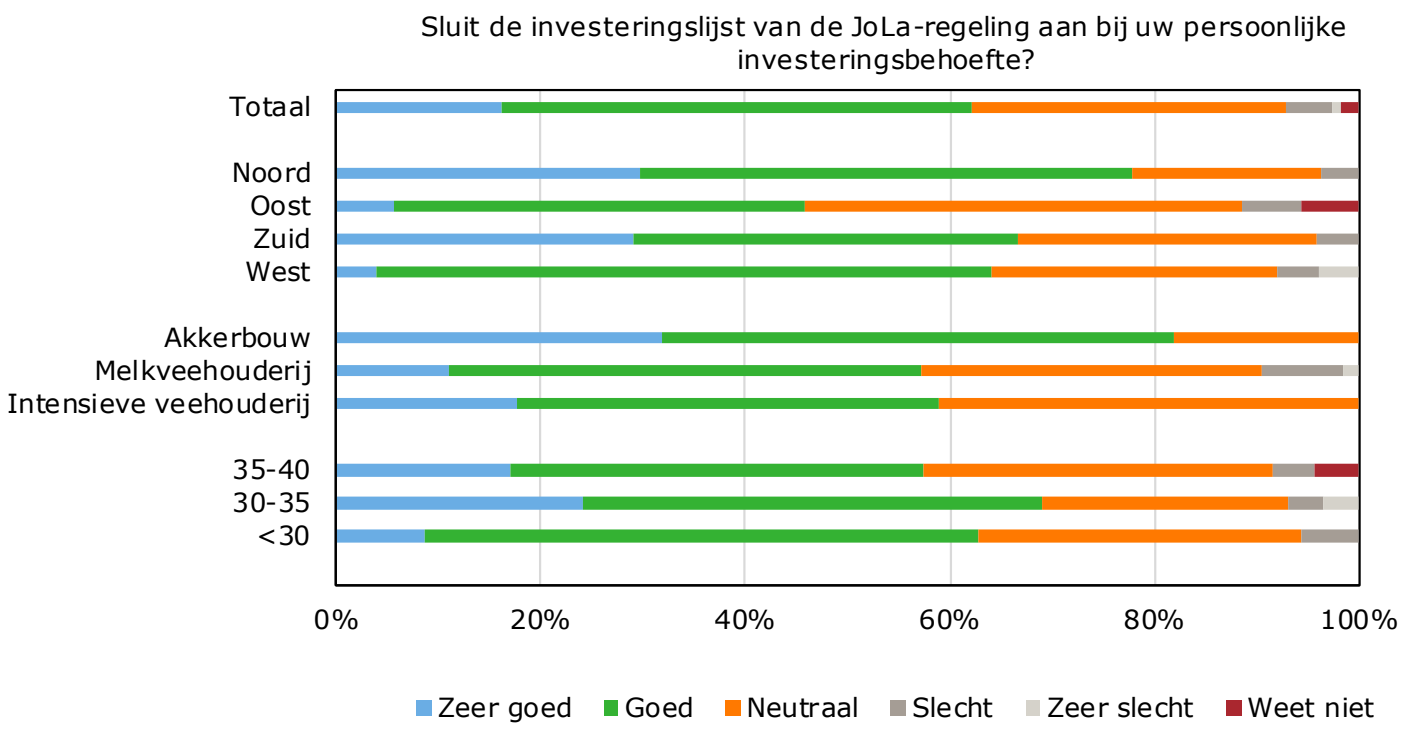

Figuur B3.1 Enquête: Aansluiting investeringsbehoefte

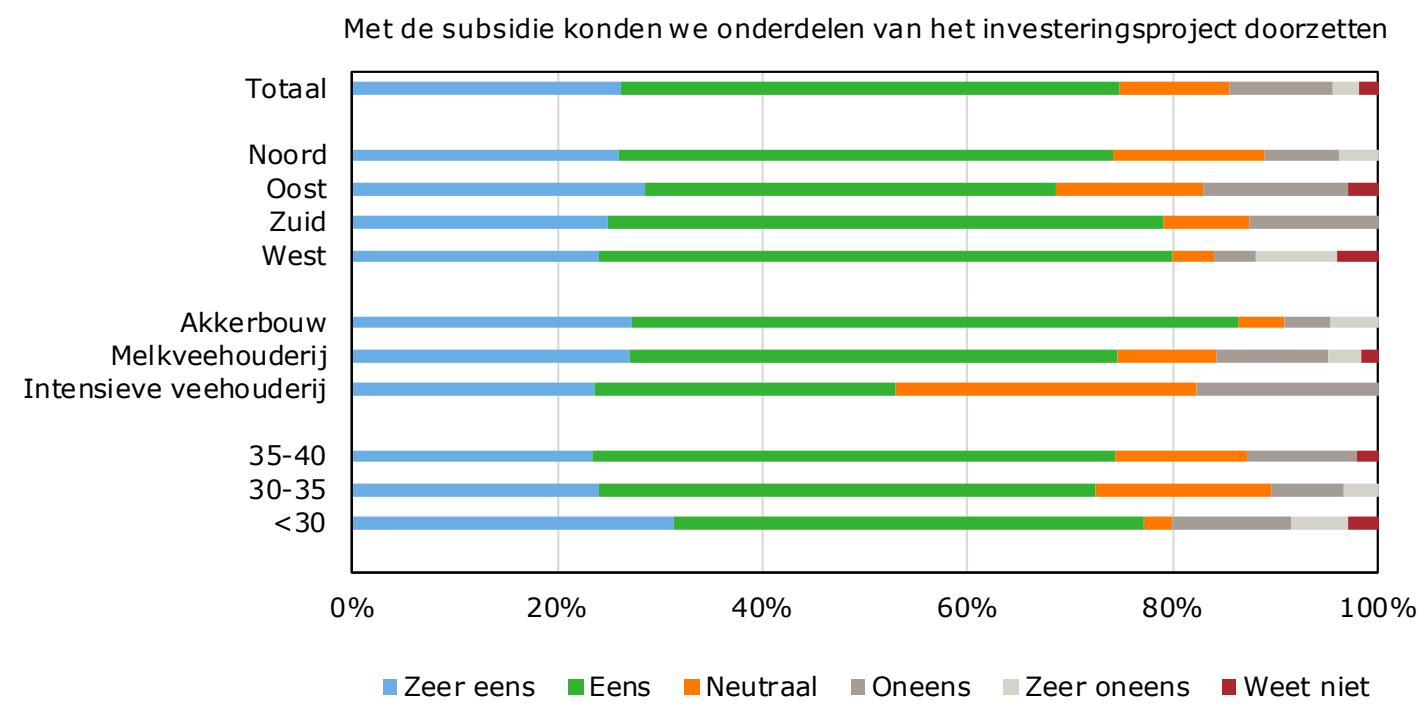

Figuur B3.2 Enquête: Doorzetten onderdelen investering 
Met de subsidie konden we eerder starten met het investeringsproject

Akkerbouw

Melkveehouderij Intensieve veehouderij

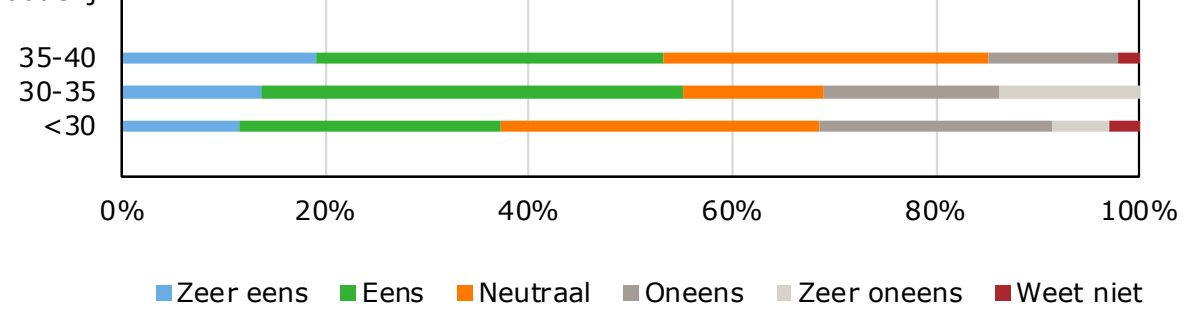

Figuur B3.3 Enquête: Eerder starten met investeringsproject

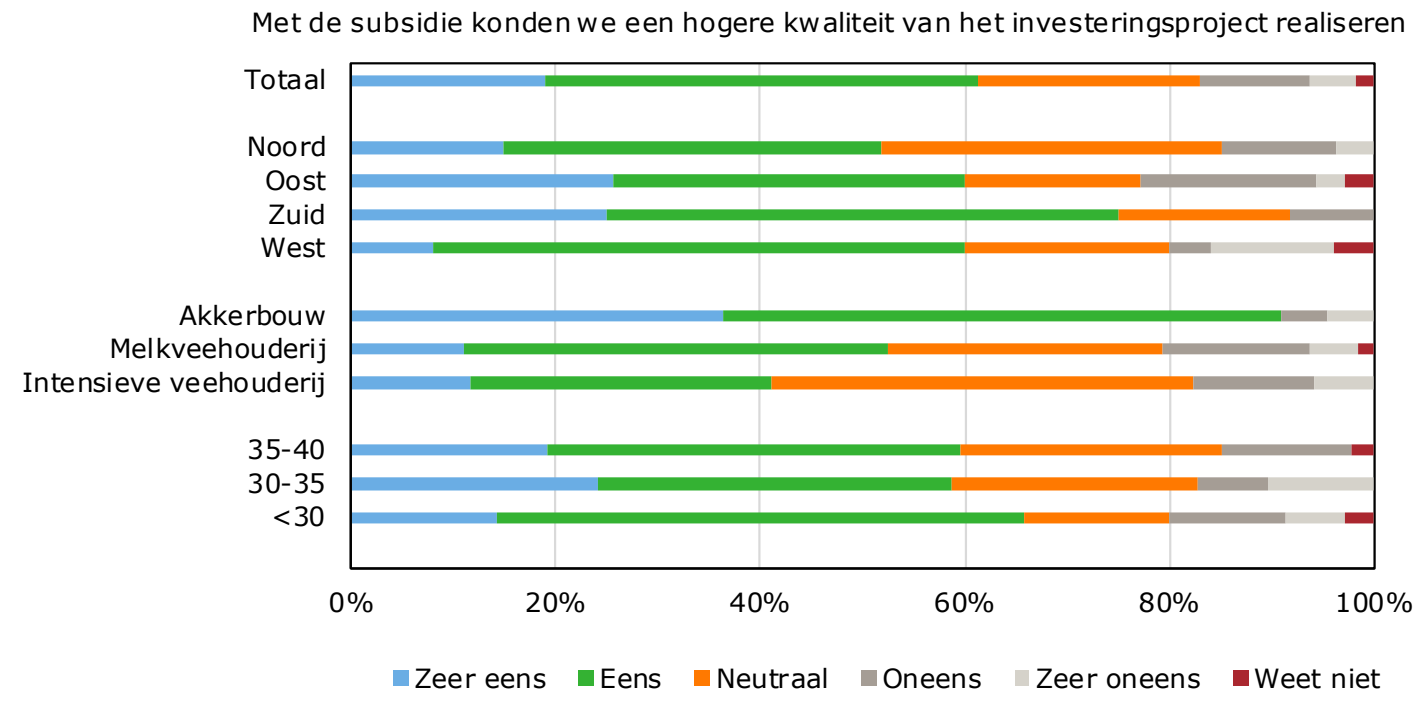

Figuur B3.4 Enquête: Hogere kwaliteit van het investeringsproject

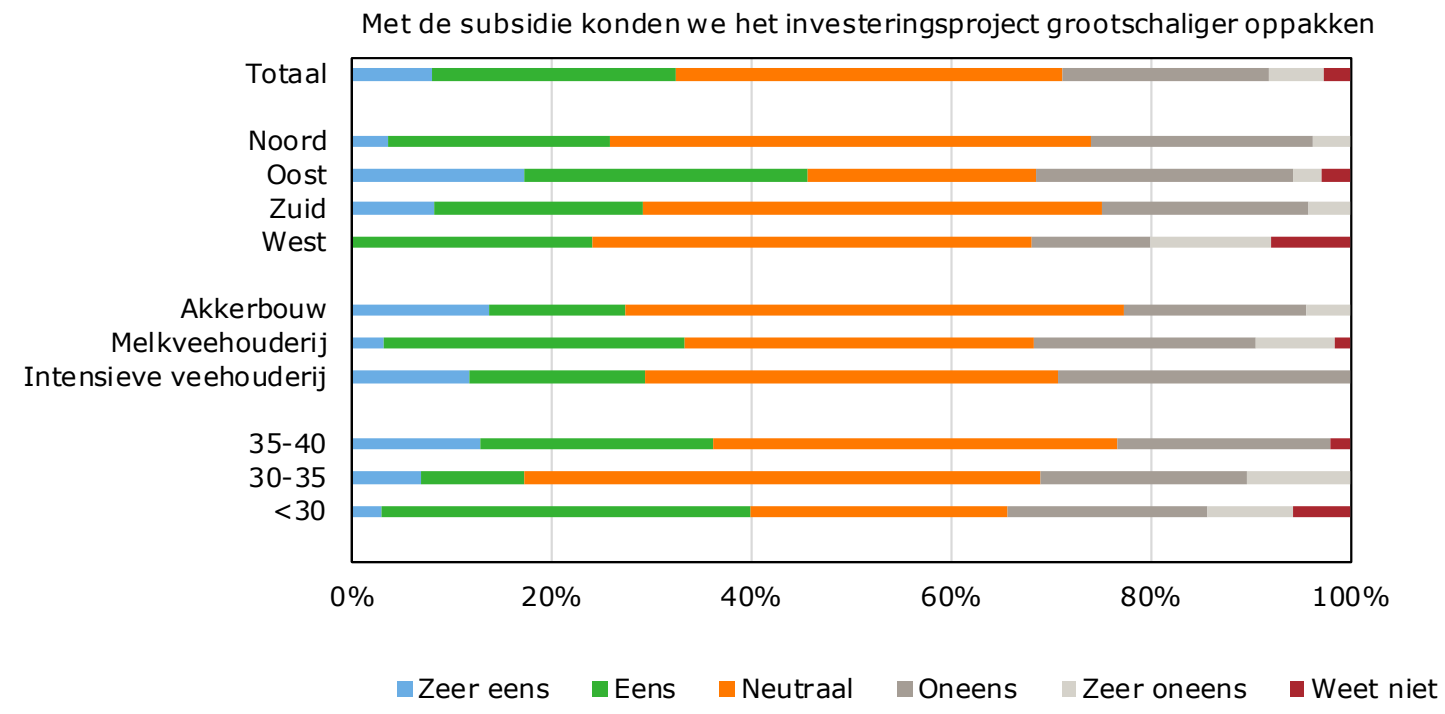

Figuur B3.5 Enquête: Investeringsproject grootschaliger oppakken 
Met de subsidie konden we de realisatie van het investeringsproject versnellen in de tijd

Akkerbouw

Melkveehouderi

Intensieve veehouderij

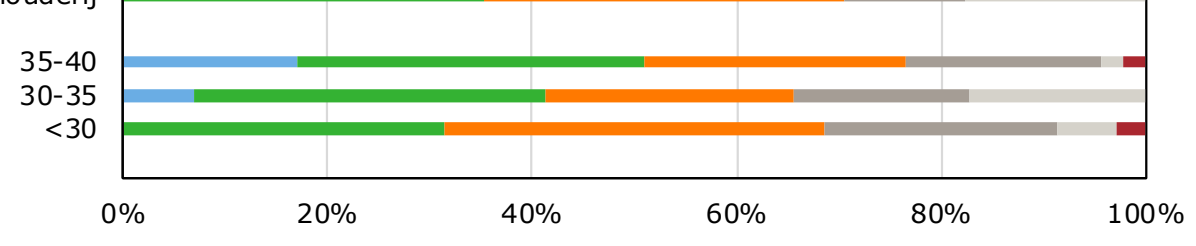

Zeer eens $\square$ Eens $\square$ Neutraal $\square$ Oneens Zeer oneens $\square$ Weet niet

Figuur B3.6 Enquête: Versnellen investeringsproject

Effecten op de prestaties en continuïteit: verhoging van de omzet

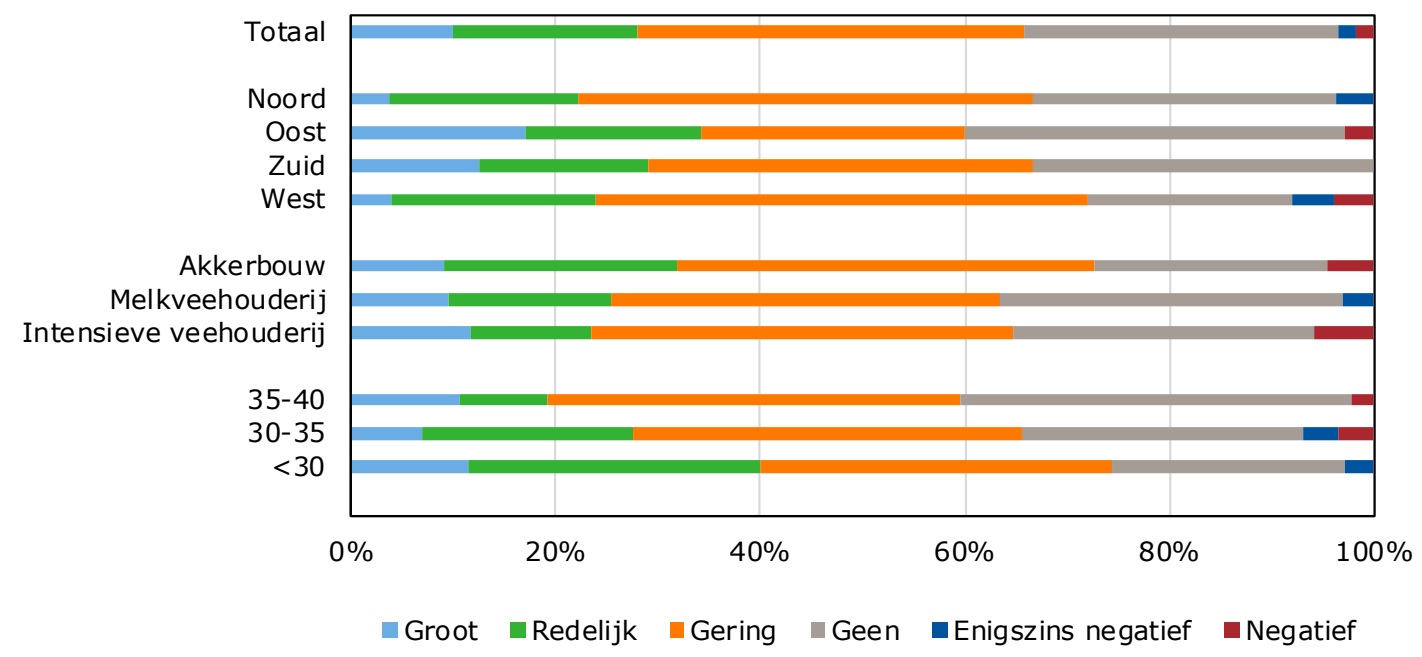

Figuur B3.7 Enquête: Verhoging omzet

Effecten op de prestaties en continuïteit: verlaging van de productiekosten

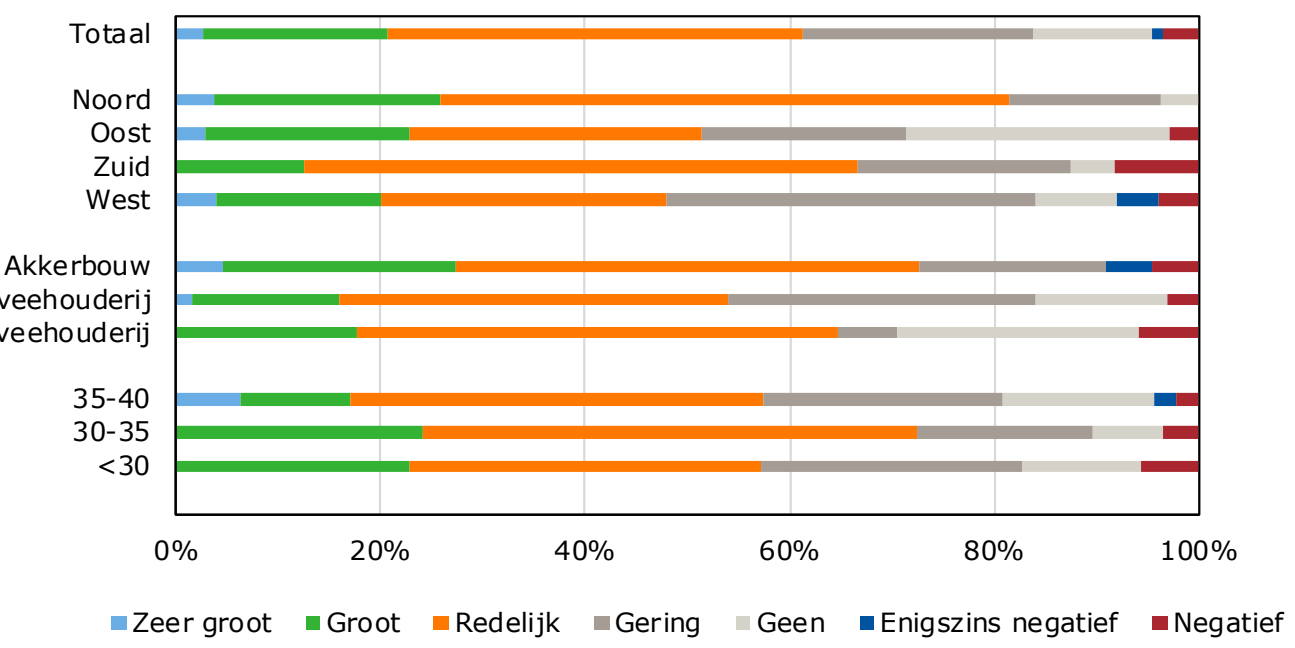

Figuur B3.8 Enquête: Verlaging productiekosten 
Effecten op de prestaties en continuïteit: modernisering van het bedrijf

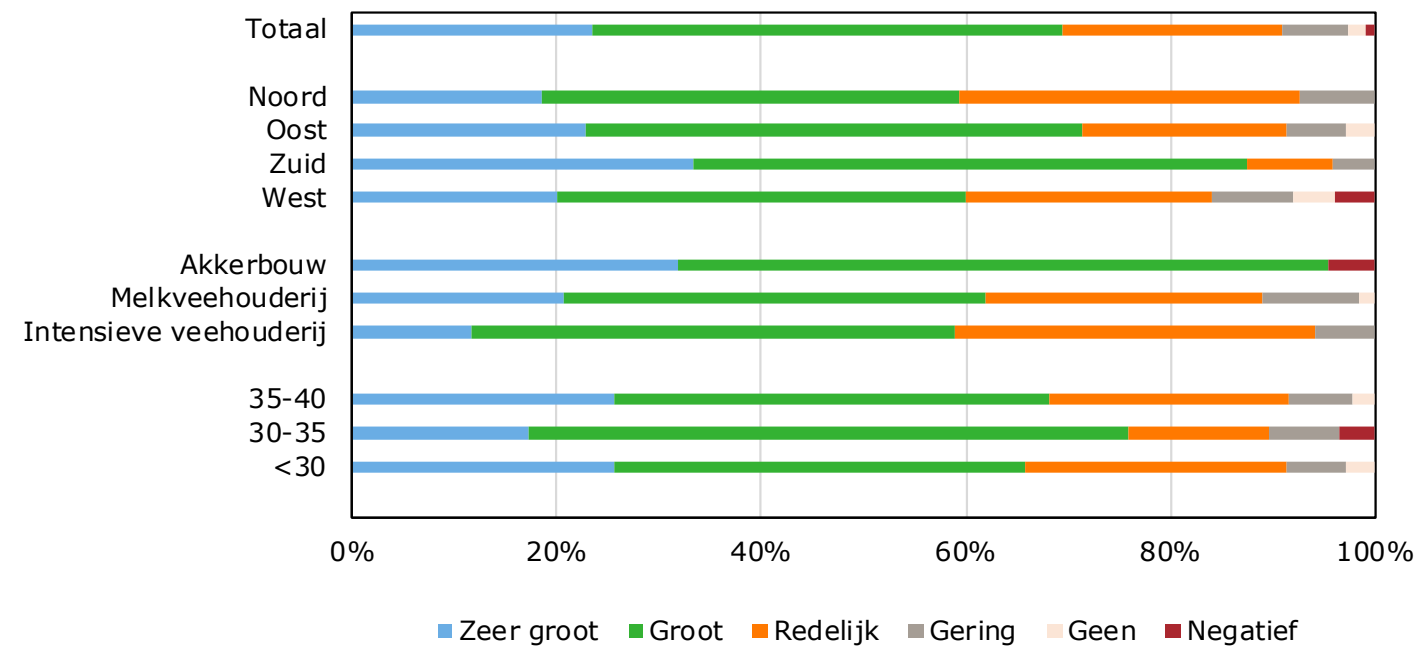

Figuur B3.9 Enquête: Modernisering van het bedrijf

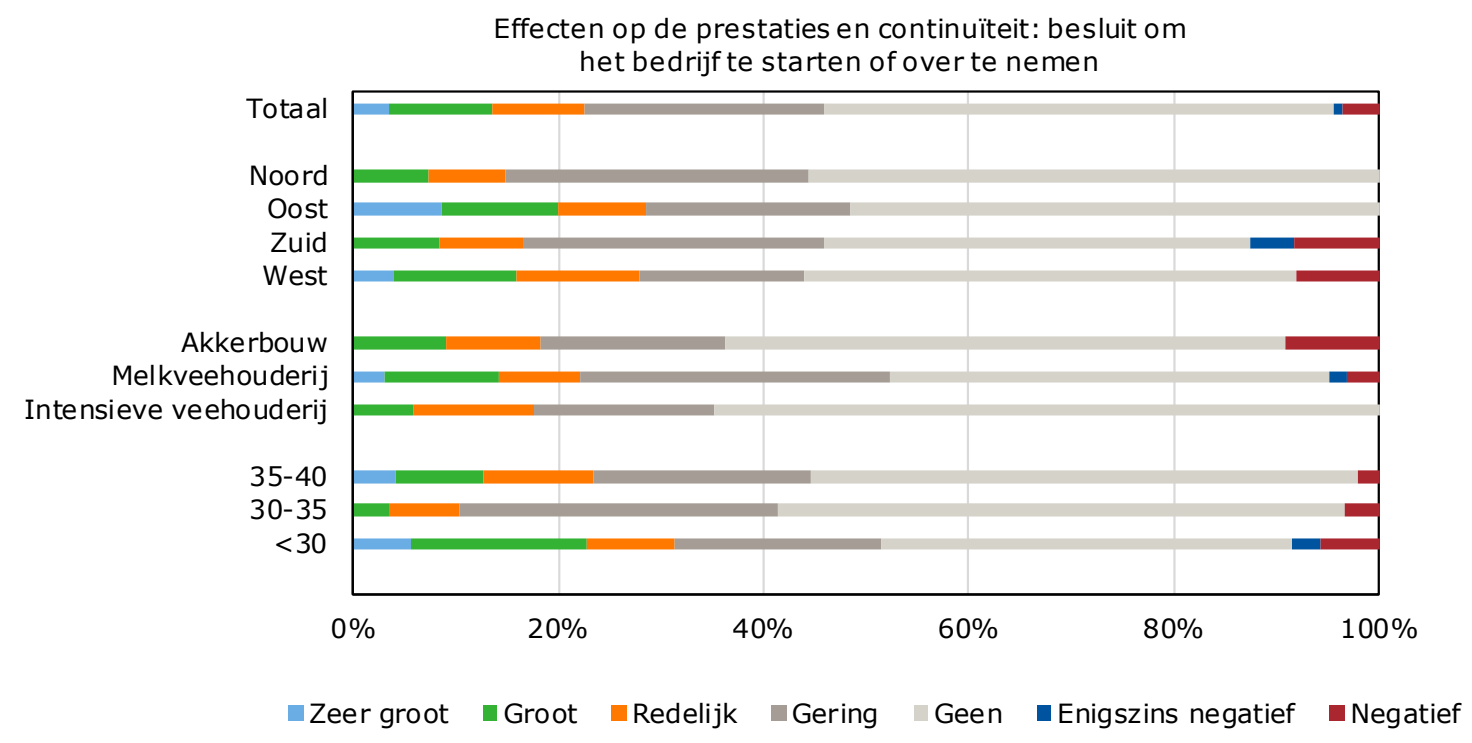

Figuur B3.10 Enquête: Overname of starten bedrijf 


\section{Bijlage 4 Maatregel Verbetering verkaveling}

\section{Geïnterviewde personen}

- Erwin van den Berg, STIVAS

- Gerrit-Jan van der Veen, Kadaster te Zwolle

- Carlo Vromans, Landelijk Kadaster te Apeldoorn

- Jos Stemkens, Kadaster te Eindhoven

- Herman Bouman (POP3 coördinator provincie Groningen)

- Mart Mensink (POP3 coördinator provincie Gelderland)

- Johan Wandel (beleidsmedewerker provincie Zeeland)

- John Stocks, beleidsmedewerker provincie Gelderland, Glastuinbouw

- Informatie uit lopend onderzoek landbouwstructuur provincie Overijssel (Interviews gehouden in meerdere provincies)

Tabel B4.1 Regeling Herverkaveling van landbouwbedrijven Verleende bedragen ( $x € 1.000)$ Regeling Herverkaveling van landbouwbedrijven per provincie, 2016 tot en met 2018

\begin{tabular}{lrrrr} 
& 2016 & 2017 & 2018 & Totaal \\
Noord-Holland & 3.344 & 0 & 4.441 & 7.785 \\
\hline Gelderland & 0 & 4.138 & 1.692 & 5.830 \\
\hline Zeeland & 0 & 4.381 & 0 & 4.381 \\
\hline Friesland & 0 & 3.100 & 0 & 3.100 \\
\hline Limburg & 0 & 1.410 & 794 & 2.204 \\
\hline Flevoland & 0 & 0 & 2.060 & 2.060 \\
\hline Overijssel & 94 & 561 & 879 & 1.534 \\
\hline Utrecht & 0 & 0 & 0 & 405 \\
\hline Drenthe & 0 & 400 & 0 & 400 \\
\hline Groningen & 0 & 266 & 10.271 & 260 \\
\hline Totaal & 3.438 & 14.256 & & 27.965 \\
\hline
\end{tabular}

Bron: RVO. 
Tabel B4.2 POP3 Kavelruilprojecten in uitvoering

\begin{tabular}{|c|c|c|c|c|}
\hline Provincie & Project(en) & Beschikt bedrag & $\begin{array}{l}\text { Beoogde } \\
\text { geruilde ha }\end{array}$ & Andere doelen \\
\hline Groningen & Planmatige kavelruil Groningen & $€ 266.000$ & 250 & $\begin{array}{l}\text { Natuur, water en } \\
\text { verkeersveiligheid }\end{array}$ \\
\hline Fryslân & Kavelruil foar Fryslân & $€ 3.100 .000$ & 1800 & Weidevogels en natuur \\
\hline Drenthe & Planmatige kavelruil Drenthe & $€ 400.000$ & 800 a 1000 & $\begin{array}{l}\text { Natuur, water en } \\
\text { verkeersveiligheid }\end{array}$ \\
\hline \multirow[t]{4}{*}{ Overijssel } & 1. Vrijwillige kavelruil Hardenberg & $€ 117.895$ & 90 & Water en verkeersveiligheid \\
\hline & 2. Planmatige kavelruil N35 & $€ 320.050$ & 150 & Water- en natuurdoelen \\
\hline & 3. Kavelruil Veldhoek e.o. & $€ 94.310$ & 60 & Water- en natuurdoelen \\
\hline & 4. Vrijwillige kavelruil Zeldam e.o. & $€ 118.588$ & 75 & Water- en natuurdoelen \\
\hline \multirow[t]{3}{*}{ Gelderland } & $\begin{array}{l}\text { 1. Kavelruil Groenlo Zuid - } \\
\text { Lichtenvoorde }\end{array}$ & $€ 273.320$ & 160 & Natuur en recreatie \\
\hline & 4. Kavelruil Midden Achterhoek & $€ 348.000$ & 290 & - \\
\hline & $\begin{array}{l}\text { 5. Vrijwillige kavelruil Gelderland } \\
\text { West }\end{array}$ & $€ 350.000$ & 350 & - \\
\hline Noord-Holland & Kavelruil Werkt! & $€ 3.300 .000$ & 1650 & Natuur, water en recreatie \\
\hline \multirow[t]{2}{*}{ Zeeland } & 1. Kavelruilbureau Zeeland & $€ 3.023 .650$ & 2100 & Water- en natuurdoelen \\
\hline & $\begin{array}{l}\text { 2. Parallelle landbouw-route } \\
\text { Absdale-Hulst }\end{array}$ & $€ 1.357 .690$ & & 1.765 meter landbouwroute \\
\hline \multirow{6}{*}{ Limburg } & 3. Verkavelen voor Groei 'Beek' & $€ 75.815$ & 80 & - \\
\hline & $\begin{array}{l}\text { 4. Verkavelen voor Groei } \\
\text { 'Haler/Hunsel' }\end{array}$ & $€ 142.063$ & 75 & - \\
\hline & $\begin{array}{l}\text { 5. Verkavelen voor Groei } \\
\text { 'Koningsbosch' }\end{array}$ & $€ 142.063$ & 75 & - \\
\hline & 6. Verkavelen voor Groei 'Meijel' & $€ 189.163$ & 100 & - \\
\hline & $\begin{array}{l}\text { 7. Verkavelen voor Groei 'Kessel- } \\
\text { Baarlo' }\end{array}$ & $€ 189.163$ & 100 & - \\
\hline & 8. Kavelruil Limburg 2016-2020 & $€ 264.380$ & 200 & - \\
\hline TOTAAL & 23 projecten & $€ 14.726000$ & 8.910 ha & \\
\hline
\end{tabular}

Bron: Informatie Regiebureau POP (stand van zaken per 1-7 2019).

In het tweede deel van 2018 zijn ook een aantal projecten ingediend/beoordeeld. De informatie beschikbaar is niet compleet bij Regiebureau POP. Alleen is bekend dat het totale budget oploopt tot $€$ 18.184.000. De aanvulling zit in de provincies Drenthe ( $€ 1.600 .000$, nog goed te keuren per 1-1-2019), $€ 1.053 .000$ (Limburg) en $€ 770.000$ (Overijssel).

\section{Verplaatsingsregeling Glastuinbouw Gelderland}

Naast de kavelruilprojecten in tabel B4.2 heeft de provincie Gelderland in het kader van maatregel $4 \mathrm{j}$ nog 4 projecten beschikt op het gebied van Reconstructie Glastuinbouw met een totaalbedrag van $€$ 3.189.200. Tabel B4.3 geeft informatie over het bereik binnen de verplaatsingsregeling Glastuinbouw Gelderland voor de hele periode 2009-2017. 
Tabel B4.3 Overzicht kasoppervlakte behorend bij de aanvragen voor bedrijfsverplaatsing in de provincie Gelderland, periode 2009-2017 (ha en tussen haakjes aantal)

\begin{tabular}{|c|c|c|c|c|}
\hline Gewasgroep & $\begin{array}{l}\text { Oppervlakte vóór } \\
\text { bedrijfsverplaatsing }\end{array}$ & $\begin{array}{l}\text { Oppervlakte } \\
\text { sprokkel locaties }\end{array}$ & $\begin{array}{l}\text { Totaal te saneren } \\
\text { kasoppervlakte }\end{array}$ & $\begin{array}{l}\text { Oppervlakte ná } \\
\text { bedrijfsverplaatsing }\end{array}$ \\
\hline Pot- en perkplanten & $11,4(9)$ & $20,8(44)$ & 32,2 & $14,0^{1}$ \\
\hline Snijbloemen & $43,6(19)$ & $26,6(52)$ & 70,2 & 70,4 \\
\hline $\begin{array}{l}\text { Vermeerdering en } \\
\text { veredeling }\end{array}$ & $2,2(2)$ & . & 2,2 & 2,4 \\
\hline Tuinplanten & $1,1(1)$ & $3,9(10)$ & 5,0 & 12,0 \\
\hline Gewas onbekend & $0,3(1)$ & . & 0,3 & 3,3 \\
\hline Totaal aanvragen & $60,7(37)$ & $54,3(113)$ & 115,0 & 117,0 \\
\hline W.v. niet gehonoreerd & $3,9(5)$ & $0,5(2)$ & 4,4 & $15,7^{2}$ \\
\hline
\end{tabular}

${ }^{1}$ In één geval is vanwege het ontbreken van informatie aangenomen dat de oppervlakte in de nieuwe situatie identiek is aan die van de situatie vóór verplaatsing. ${ }^{2}$ Beoogde oppervlakte na verplaatsing.

Bron: Provincie Gelderland; bewerking Wageningen Economic Research.

Bij de 30 uitgevoerde bedrijfsverplaatsingen was in totaal 108,5 ha te saneren oppervlakte betrokken, inclusief 51,2 ha aan ingebrachte sprokkellocaties. Na verplaatsing is 99,6 ha aan 'nieuwbouw' teruggekomen (zie tabel 3.1). 


\section{Bijlage 5 Budgetten cluster Concurrentiekracht}

Tabel B5.1 Budget ( $€$ m/n.) indeling per organisatie thema Concurrentiekracht basis (start POP3)

\begin{tabular}{|c|c|c|c|c|c|c|}
\hline \multirow{2}{*}{$\begin{array}{l}\text { Organisatie/ } \\
\text { Maatregel }\end{array}$} & 3 & 4.1 .1 & 4.1 .2 & 4.3 & 17.1 .0 & \\
\hline & $\begin{array}{l}\text { Kwaliteits } \\
\text { verbetering } \\
\text { Kalveren }\end{array}$ & $\begin{array}{l}\text { Productieve } \\
\text { fysieke } \\
\text { investeringen }\end{array}$ & $\begin{array}{l}\text { Jonge } \\
\text { landbouwers }\end{array}$ & $\begin{array}{l}\text { Verbetering } \\
\text { landbouw } \\
\text { infrastructuur }\end{array}$ & $\begin{array}{l}\text { Brede } \\
\text { weersver } \\
\text { zekering }\end{array}$ & $\begin{array}{l}\text { Totaal } \\
\text { organisatie }\end{array}$ \\
\hline Groningen & & 11,10 & 2,90 & 11,56 & & 25,56 \\
\hline Friesland & & 4,90 & 3,62 & 14,64 & & 23,16 \\
\hline Drenthe & & 5,94 & 2,90 & 11,56 & & 20,40 \\
\hline Overijssel & & 8,74 & 3,52 & 8,68 & & 20,94 \\
\hline Gelderland & & 6,14 & 3,72 & 14,04 & & 23,90 \\
\hline Flevoland & & 6,85 & 2,38 & 2,06 & & 11,29 \\
\hline Utrecht & & 3,44 & 2,14 & 4,14 & & 9,72 \\
\hline Noord-Holland & & 9,36 & 2,74 & 11,98 & & 24,08 \\
\hline Zuid-Holland & & 11,93 & 2,74 & 0,00 & & 14,67 \\
\hline Zeeland & & 7,42 & 2,70 & 13,80 & & 23,92 \\
\hline Noord Brabant & & 11,82 & 3,92 & 8,68 & & 24,42 \\
\hline Limburg & & 9,53 & 2,48 & 7,02 & & 19,03 \\
\hline Rijk & 30,00 & 20,00 & 0,00 & 0,00 & 41,69 & 91,69 \\
\hline Totaal Nederland & 30,00 & 117,17 & 35,76 & 108,16 & 41,69 & 332,78 \\
\hline
\end{tabular}

Bron: Regiebureau POP.

Tabel B5.2 Voorgestelde budget ( $€ \mathrm{~m} / \mathrm{n}$.) indeling per organisatie thema Concurrentiekracht aangepast 1

\begin{tabular}{|c|c|c|c|c|c|c|}
\hline \multirow{2}{*}{$\begin{array}{l}\text { Organistie / } \\
\text { Maatregel }\end{array}$} & 3 & 4.1 .1 & 4.1 .2 & 4.3 & 17.1 .0 & \\
\hline & $\begin{array}{c}\text { Kwaliteits } \\
\text { verbetering } \\
\text { Kalveren }\end{array}$ & $\begin{array}{c}\text { Productieve } \\
\text { fysieke } \\
\text { investeringen }\end{array}$ & $\begin{array}{c}\text { Jonge } \\
\text { landbouwers }\end{array}$ & $\begin{array}{l}\text { Verbetering } \\
\text { landbouw } \\
\text { infrastructuur }\end{array}$ & $\begin{array}{l}\text { Brede } \\
\text { weersver } \\
\text { zekering }\end{array}$ & $\begin{array}{c}\text { Totaal } \\
\text { organisatie }\end{array}$ \\
\hline Groningen & & 10,34 & 2,90 & 0,46 & & 13,70 \\
\hline Friesland & & 4,14 & 3,62 & 3,14 & & 10,90 \\
\hline Drenthe & & 5,44 & 2,90 & 2,00 & & 10,34 \\
\hline Overijssel & & 2,64 & 3,52 & 2,16 & & 8,32 \\
\hline Gelderland & & 6,00 & 3,72 & 10,54 & & 20,26 \\
\hline Flevoland & & 7,13 & 2,38 & 2,06 & & 11,57 \\
\hline Utrecht & & 4,74 & 2,14 & 1,80 & & 8,68 \\
\hline Noord-Holland & & 4,68 & 2,74 & 10,34 & & 17,76 \\
\hline Zuid-Holland & & 1,50 & 2,74 & - & & 4,24 \\
\hline Zeeland & & 7,54 & 2,70 & 10,80 & & 21,04 \\
\hline Noord Brabant & & 14,40 & 3,92 & 2,00 & & 20,32 \\
\hline Limburg & & 15,19 & 2,48 & 4,58 & & 22,25 \\
\hline Rijk & 30,00 & 20,00 & - & - & 41,69 & 91,69 \\
\hline Totaal Nederland & 30,00 & 103,74 & 35,76 & 49,88 & 41,69 & 261,07 \\
\hline
\end{tabular}

Bron: Regiebureau POP.

1) Voorstel per 31-12-2018; nog niet geëffectueerd door Comité van Toezicht. 


\section{Bijlage 6 Tussenevaluatie Brede weersverzekering}

De evaluatie van de regeling Brede weersverzekering draait om twee hoofdvragen, namelijk:

1. Is er aan het einde van de looptijd van de regeling Brede weersverzekering voor de periode 20102014 een commercieel aantrekkelijke verzekering voor de verzekeraar en voor de verzekerden, zonder overheidssteun?

2. In welke mate heeft de regeling Brede weersverzekering ertoe geleid dat het aantal en de omvang van de verzoeken tot schadevergoedingen aan het ministerie van EZ is verminderd?

Het antwoord op de eerste vraag is nee. Deze conclusie is bevestigd door zowel telers en landbouworganisaties als door verzekeraars. Aan het einde van de looptijd van de eerste regeling waren er te weinig deelnemers om een commercieel aantrekkelijke verzekering in de markt te zetten. Ondernemers geven als belangrijkste redenen om niet deel te nemen aan dat de premie en het eigen risico van de verzekering te hoog zijn en de dekking te beperkt.

Het antwoord op de tweede vraag is moeilijk objectief vast te stellen. Immers, de verzekering dekt extreem weer af dat per definitie niet frequent voorkomt. Echter, in de korte looptijd sinds openstelling van de regeling Brede weersverzekering hebben zich een aantal extreme weersituaties voorgedaan, waarbij vanuit de sectorvertegenwoordigers geen verzoek is ingediend voor een ad-hoc publieke schadeloosstelling. Het ministerie van Economische Zaken had een heldere boodschap en kon wijzen op de mogelijkheid van de regeling Brede weersverzekering met ondersteuning van de landbouworganisaties. De meest recente teeltschade van juni 2016 heeft wel geleid tot een verzoek om tegemoetkoming, maar tot op heden (juli 2016) is het ministerie van EZ hier niet in meegegaan.

\section{Bereik, doeltreffendheid, doelmatigheid}

De aannames van de overheid bij het opstellen van de regeling Brede weersverzekering dat in een periode van vier jaar alle openteeltondernemers een brede weersverzekering (BWV) zouden hebben afgesloten en iedere deelnemer zijn gehele areaal met alle gewassen zou verzekeren, zijn niet bewaarheid. Daarmee blijft het bereik van de regeling Brede weersverzekering achter bij het gestelde doel. De belangrijkste reden voor ondernemers om een BWV af te sluiten is dat dit de enige manier is om vanuit de overheid bij verzekerbare gewasschade nog een vergoeding te krijgen. De mogelijkheid om specifieke gewassen te verzekeren en het feit dat de subsidie sinds 2015 direct in mindering wordt gebracht op de te betalen premie, zijn eveneens belangrijke beweegredenen voor het afsluiten van de verzekering.

Het doel om commercieel aantrekkelijke verzekeringen voor de verzekeraar en voor de agrarische ondernemingen tot stand te brengen is niet bereikt. Het doel om het aantal verzoeken tot schadevergoeding aan het ministerie van EZ te verminderen is wel gehaald, uitgezonderd de meest recente teeltschade in juni 2016.

De indruk is dat de uitvoering door de Rijksdienst voor Ondernemend Nederland (RVO.nl) van de regeling Brede weersverzekering doelmatig gebeurt. Voor een belangrijk deel is dit toe te schrijven aan de goede samenwerking van RVO.nl met de aanbieders van een BWV én aan de mogelijkheid om de regeling Brede weersverzekering administratief samen te laten lopen met de Gecombineerde opgave (de jaarlijkse aanlevering van gegevens door agrarisch ondernemers aan RVO.nl).

De kosten voor de overheid in geval er geen regeling Brede weersverzekering zou zijn geweest in de periode 2010-2014, worden geschat op $€ 46 \mathrm{mln}$., gebaseerd op de vorstschade in de fruitteelt in 2012. Dit was een voorval waarbij in het verleden in soortgelijke gevallen tegemoetkoming werd verleend. Ter vergelijking, de jaarlijkse premiesubsidie bedroeg $€ 4,8 \mathrm{mln}$. in 2012 . De geschatte uit te betalen ad-hoc schadevergoeding is ook aanzienlijk meer - ongeveer het dubbele - dan de verstrekte premiesubsidie in de periode 2010-2014 ( $€ 23 \mathrm{mln}$.). 
Een andere benadering is om de jaarlijkse premiesubsidie van $€ 7,8 \mathrm{mln}$. in 2015 te vergelijken met de gemiddelde ad-hoc tegemoetkoming voorafgaande aan de openstelling. Deze bedroeg gemiddeld nominaal circa $€ 12 \mathrm{mln}$. per jaar (totaal circa $€ 429 \mathrm{mln}$. voor een tijdsbestek van 35 jaar). Ook in dat perspectief is de regeling Brede weersverzekering doelmatig geweest. 


\section{Bijlage 7 Tussentijdse beantwoording algemene vragen EU (bijvangst)}

In deze tussentijdse evaluatie heeft de bijdrage van de maatregelen aan de beantwoording van de algemene evaluatievragen van de EU het karakter van bijvangst. Bij de beantwoording zijn de algemene evaluatievragen van de EU geclusterd naar drie overall thema's.

\section{Duurzaamheid, klimaat, milieu en biodiversiteit}

De maatregelen Jonge Landbouwers-regeling en Productieve fysieke investeringen zetten in op het ondersteunen van bovenwettelijke investeringen. Deze investeringen worden hiermee naar voren gehaald.

Er wordt een sterke impuls gegeven aan verduurzaming op verschillende thema's zoals dierenwelzijn, energie, gesloten kringlopen, precisielandbouw, biologische landbouw en waterbeheer. Specifiek op milieu gericht zijn bijvoorbeeld investeringen in emissiebeperkende apparatuur. Hiermee zijn de ondersteunde bedrijven beter in staat in te spelen op mogelijke toekomstige regelgeving en invloeden vanuit de markt (consumentenwensen). Dit laatste is ook van toepassing door ondersteuning van keurmerk Vitaal Kalf. De ondersteuning van bedrijfsverplaatsing leidt tot moderne en innovatieve glastuinbouwbedrijven.

In de maatregelen binnen het cluster Concurrentiekracht wordt nauwelijks in biodiversiteit geïnvesteerd. De niet-productieve investeringen in onder andere biodiversiteit, natuur, landschap en water vallen niet binnen deze evaluatie.

\section{Innovatie en concurrentiekracht}

Gezien het vooral bovenwettelijke, en op verbetering duurzaamheid gerichte bedrijfsinvesteringen gaat, hebben veel van deze investeringen een innovatief karakter. Een mooi voorbeeld is de dierenwelzijnsvriendelijke vloeren en ammoniak beperkende apparatuur in de vleeskalverhouderij. De aanvragen waren echter nog niet in 2018 goedgekeurd. Ook de bedrijfsverplaatsing en oprichting nieuwe bedrijven biedt veel mogelijkheden tot moderne innovatieve bedrijven. Een ander voorbeeld is het investeren in het sluiten van kringlopen onder de regeling fysieke investeringen.

Voor een aanzienlijk deel van de bedrijven betreft het ondersteuning van een relatief kleine investering, zoals onder de regeling JoLa. Het effect op de concurrentiekracht overall is en blijft beperkt. In bepaalde bedrijfstakken en lokaal kan het effect groter uitvallen. Veel provincies sturen mede op de regionale doelen die ze willen beogen.

\section{Werk, inkomen, gebiedsontwikkeling}

De al ingezette POP3 middelen hebben nog geen meetbare effecten op inkomen en werk opgeleverd. De verwachting is dat door meerdere van de ingezette regelingen de bedrijfskosten zullen dalen, zoals minder uitval en minder antibioticagebruik in de vleeskalversector, door modernisering en nieuwe innovaties, en door verkaveling.

De effecten op werkgelegenheid zullen zeer beperkt zijn. Een klein deel van de ondersteunde bedrijven verkrijgt een sterker bedrijfsperspectief en daarmee opvolgingsperspectief, en daarmee behoud van werkgelegenheid. Dit kan in een aantal plattelandsgebieden leiden tot minder krimp. Verkaveling en bedrijfsverplaatsing hebben wel geleid tot tijdelijk meer arbeidsinzet tijdens de uitvoering.

Door ondersteuning van verkavelingsprojecten met meerdere doelen (landbouw, natuur, water), ongeveer de helft van het aantal projecten, wordt een goede impuls gegeven aan integrale gebiedsontwikkeling. Voor de Veenkoloniën, een gebied dat ter compensatie van veranderend GLBbeleid in POP3 ondersteuning krijgt via de regeling Fysieke investeringen in innovatie en modernisering, betekent de impuls via investeringen in apparatuur een welkome economische ondersteuning. 
Wageningen Economic Research Postbus 29703

2502 LS Den Haag

T 0703358330

Ecommunications.ssg@wur.nl

www.wur.nl/economic-research

Wageningen Economic Research RAPPORT

2019-065
De missie van Wageningen University \& Research is 'To explore the potential of nature to improve the quality of life'. Binnen Wageningen University \& Research bundelen Wageningen University en gespecialiseerde onderzoeksinstituten van Stichting Wageningen Research hun krachten om bij te dragen aan de oplossing van belangrijke vragen in het domein van gezonde voeding en leefomgeving. Met ongeveer 30 vestigingen, 5.000 medewerkers en 10.000 studenten behoort Wageningen University \& Research wereldwijd tot de aansprekende kennisinstellingen binnen haar domein. De integrale benadering van de vraagstukken en de samenwerking tussen verschillende disciplines vormen het hart van de unieke Wageningen aanpak. 



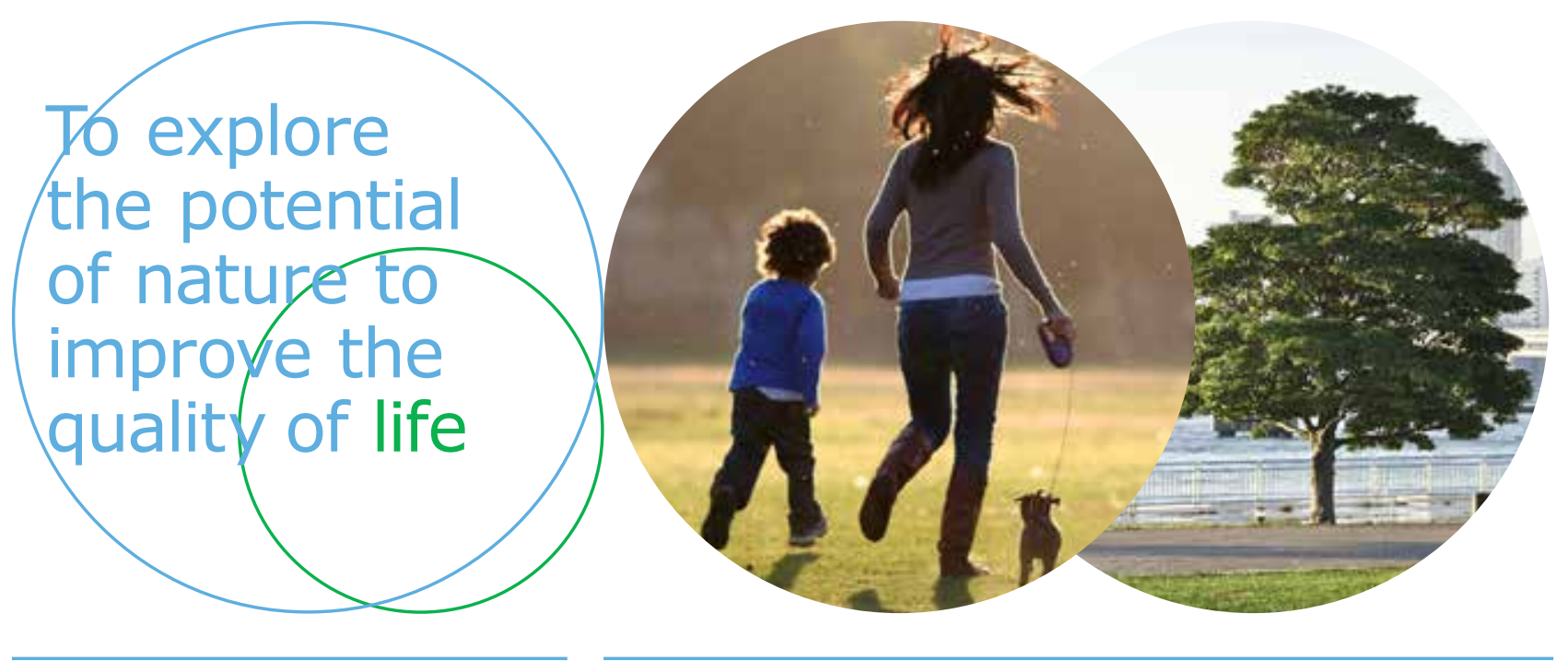

Wageningen Economic Research Postbus 29703

2502 LS Den Haag

E communications.ssg@wur.nl

T+31(0)7033583 30

www.wur.nl/economic-research

Rapport 2019-065

ISBN 978-94-6395-010-7
De missie van Wageningen University \& Research is 'To explore the potential of nature to improve the quality of life'. Binnen Wageningen University \& Research bundelen Wageningen University en gespecialiseerde onderzoeksinstituten van Stichting Wageningen Research hun krachten om bij te dragen aan de oplossing van belangrijke vragen in het domein van gezonde voeding en leefomgeving. Met ongeveer 30 vestigingen, 5.000 medewerkers en 10.000 studenten behoort Wageningen University \& Research wereldwijd tot de aansprekende kennisinstellingen binnen haar domein. De integrale benadering van de vraagstukken en de samenwerking tussen verschillende disciplines vormen het hart van de unieke Wageningen aanpak. 